\title{
Pitanje broja žrtava logora Jasenovac u hrvatskoj i srpskoj historiografiji, publicistici i javnosti nakon raspada SFR Jugoslavije - činjenice, kontroverze i manipulacije*
}

\author{
VLADIMIR GEIGER \\ Hrvatski institut za povijest \\ Zagreb, Republika Hrvatska \\ geiger@isp.hr
}

Najkontroverznije i neriješeno pitanje ljudskih gubitaka Hrvatske, i Jugoslavije, u Drugome svjetskom ratu broj je žrtava logora Jasenovac. Popisi žrtava logora Jasenovac te procjene i izračuni povjesničara i demografa najčešće su znatno različiti i u preširokom rasponu od potpunoga umanjivanja do nemogućih megalomanskih navoda te uvjetovani (dnevno)političkim ozračjem. Napose od vremena raspada SFR Jugoslavije pitanje broja žrtava logora Jasenovac iz jedinoga mogućega jednostranog i „megalomanskog” tumačenja znatno se raslojava. U članku se prikazuju i propituju najvažniji historiografski i publicistički radovi o jasenovačkim žrtvama i njihovi odjeci u javnosti, od pristaša „umanjivanja” do zastupnika „megalomanskih” navoda, kao i malobrojna nastojanja nepristranoga sagledavanja toga pitanja u Hrvatskoj i Srbiji od početka 90 -ih godina do sadašnjosti.

Ključne riječi: Nezavisna Država Hrvatska; logor Jasenovac; žrtve; kontroverze; manipulacije

\footnotetext{
Ovaj članak nastao je u sklopu projekta Rat, žrtve, nasilje i granice slobode u hrvatskoj povijesti 20. stoljeća (IP-2019-04) Hrvatskoga instituta za povijest, koji financira Hrvatska zaklada za znanost.
} 
Jedno od najzamršenijih pitanja hrvatske i srpske historiografije jest broj i nacionalna/etnička struktura žrtava logora Jasenovac. Raspad Socijalističke Federativne Republike (SFR) Jugoslavije otvorio je mogućnost znatnijih promjena u historiografijama, i hrvatskoj i srpskoj. Demokratske promjene, ali i uznapredovali nacionalizmi u ozračju rata 90 -ih godina XX. stoljeća početno su uvjetovali da propitivanja o ljudskim gubicima Jugoslavije u Drugome svjetskom ratu, i nezaobilazno pitanje broja i strukture žrtava logora Jasenovac, u hrvatskoj i srpskoj historiografiji te publicistici i javnosti imaju ponajprije prepoznatljivu ideološko-promidžbenu podlogu. Srpski nacionalisti enormno uvećavaju broj žrtava logora Jasenovac, ponajprije Srba, a hrvatski nacionalisti broj jasenovačkih žrtava potpuno umanjuju. Pitanje broja i strukture jasenovačkih žrtava prepuno je nacionalnoga, političkoga, svjetonazorskoga i emocionalnoga naboja, koji znatno otežavaju prosudbu. Zagovornici i lijevoga i desnoga svjetonazora i u Hrvatskoj i u Srbiji upinju se i dalje prešutjeti i omalovažiti svako istraživanje i činjenice koje ne podržavaju njima poželjnu sliku prošlosti. Ujedno činjenice koje su postale neupitne nastoje obezvrijediti i iznositi njima svojstvena obrazloženja. Uvećavanje ili umanjivanje, pa i prešućivanje, najčešće uz neznanje, proizlazi iz osobnih, nacionalnih ili političkih razloga. Zamjetno je da su hrvatski i srpski mediji pretežito transmisija upravo takvih nastojanja. O logoru Jasenovac i broju i strukturi žrtava i danas se i u hrvatskoj i u srpskoj historiografiji i publicistici, koje su se od početka 90-ih godina i u nacionalnim okvirima raslojile lijevo i desno, a i u hrvatskoj i srpskoj javnosti uvelike raspravlja i donose različiti, pa i suprotstavljeni navodi i tvrdnje, često neutemeljeni. Činjenice o logoru Jasenovac od početka su kontaminirane, a svjedoci smo kontaminacije s raznih strana kojoj se teško nazire kraj. Uza sav uloženi trud dijela hrvatske i srpske historiografije, ali i publicistike, u istraživanju i objedinjavanju spoznaja i novih podataka o broju i strukturi žrtava logora Jasenovac, nismo se uvjerljivo odmaknuli od onoga što je o jasenovačkom logoru i prije bilo poznato i jasno. Nedvojbeno, historiografija, i hrvatska i srpska, tek treba donijeti utemeljene odgovore o broju i strukturi jasenovačkih žrtava. Ovim člankom pokušavam predočiti najvažnije autore i radove hrvatske i srpske historiografije i publicistike, i nezaobilazne odjeke u hrvatskoj i srpskoj javnosti, koji propituju broj i strukturu žrtava logora Jasenovac, i one koji donose utemeljene činjenice, ali i ogledne primjere nedvojbenoga neznanja i manipulacija. 
Promicanje brojke od 100.000 žrtava logora Jasenovac nakon raspada SFR Jugoslavije u Republici Hrvatskoj - Vladimir Žerjavić / Slavko Goldstein \& Ivo Goldstein i sljedbenici

O ljudskim gubicima Jugoslavije, i Hrvatske, u Drugome svjetskom ratu, pa i o žrtvama logora Jasenovac te njihovoj nacionalnoj/etničkoj strukturi postoje različite procjene i izračuni. U hrvatskoj historiografiji i javnosti posljednjih se desetljeća najčešće spominju izračuni/procjene Vladimira Žerjavića. - U svojoj knjizi Opsesije i megalomanije oko Jasenovca i Bleiburga. Gubici stanovništva Jugoslavije u drugom svjetskom ratu (1992.) Žerjavić spominje da u svojoj prethodnoj knjizi, Gubici stanovništva Jugoslavije u drugom svjetskom ratu (1989.), ${ }^{1}$ nije ,istraživao ni izračunavao" koliko je ljudi ubijeno u logoru Jasenovac, ali da se iz njegovih izračuna moglo zaključiti da se radi o „oko 100 tisuća". ${ }^{2}$ U knjizi Opsesije i megalomanije oko Jasenovca i Bleiburga Žerjavić je tu brojku korigirao i smanjio na oko 83.000 osoba, od čega 45.000 do 52.000 Srba, 13.000 Židova, 10.000 Roma, 10.000 Hrvata i 2000 Muslimana. ${ }^{3}$ Nedugo zatim u svojem članku „Manipulacije žrtvama drugoga svjetskog rata 1941. - 1945.", objavljenom 1992. u Časopisu za suvremenu povijest, Žerjavić je broj žrtava logora Jasenovac opet neznatno povećao na 85.000 (50.000 Srba, 13.000 Židova, 12.000 Hrvata i Muslimana i $10.000 \mathrm{Roma})^{4}$, a isto će navoditi i poslije, 1993. i 1995. godine, u svojim člancima i knjigama. ${ }^{5}$ Žerjavić je i u svojem izlaganju „The Most Likely Number of Victims of the Jasenovac Camp” na Prvoj međunarodnoj konferenciji i izložbi o jasenovačkim koncentracijskim logorima (The First International Conference and Exhibit on the Jasenovac Concentration Camps) u listopadu 1997. u New Yorku iznio da je prema njegovu izračunu/procjeni u logoru Jasenovac život izgubilo ukupno oko 85.000 osoba (48.000 - 52.000 odnosno 50.000 Srba, 13.000 Židova, 12.000 Hrvata i 10.000 Roma). ${ }^{6}$ Potkraj 90 -ih godina Žerjavić u svojim knjigama Population losses in Yugoslavia 1941-1945 i Pertes de la population en Yougoslavie 1941-1945, koje su prijevod njegove knjige Opsesije i megalomanije oko Jasenovca i Bleiburga, ponavlja ondje iznesene brojke: 83.000 (45.000 do 52.000 Srba, 13.000 Židova, 10.000 Roma, 10.000 Hrvata i 2000 Muslimana). ${ }^{7}$ Na kraju, Žerjavić će se 2001.

\footnotetext{
ŽERJAVIĆ, Gubici stanovništva Jugoslavije u drugom svjetskom ratu.

ŽERJAVIĆ, Opsesije i megalomanije oko Jasenovca i Bleiburga, 43, 69.

Isto, 72 .

Usp. ŽERJAVIĆ, „Manipulacije žrtvama drugoga svjetskog rata 1941. - 1945.”, 161.

Usp. primjerice: ŽERJAVIĆ, Yugoslavia - manipulations with the numbers of Second World War victims, 29, 63-64, 93-94, 121 i ŻERJAVIĆ, „Demografski i ratni gubici Hrvatske u Drugom svjetskom ratu i poraću", 556.

6 Usp. ŽERJAVIĆ, [„,The Most Likely Number of Victims of the Jasenovac Camp”], 208, 211.

7 Usp. ŽERJAVIĆ, Population losses in Yugoslavia 1941-1945, 92 i ŽERJAVIĆ, Pertes de la population en Yougoslavie 1941-1945, 101.
} 
godine odrediti da je broj žrtava logora Jasenovac oko 85.000 (48.000 - 52.000 odnosno 50.000 Srba, 13.000 Židova, 12.000 Hrvata i 10.000 Roma). ${ }^{8}$ Dakle, Žerjavić je u svojim izračunima zastupao brojku od 83.000 odnosno 85.000 žrtava logora Jasenovac.

No ovdje je potrebno zastati i vratiti se na početak priče o Žerjavićevim izračunima o broju žrtava logora Jasenovac, u 1989., 1990. i 1991. godinu. Žerjavić, kako je spomenuto, u knjizi Opsesije i megalomanije oko Jasenovca i Bleiburga piše 1992. da u svojoj knjizi Gubici stanovništva Jugoslavije u drugom svjetskom ratu (1989.) nije „istraživao ni izračunavao” koliko je žrtava logora Jasenovac, ali se iz njegovih izračuna moglo zaključiti da je riječ o „oko 100 tisuća”. ${ }^{9}$ A ko je uistinu tako, nejasno je zašto Žerjavić u svojem članku „Stradanja Jugoslavena u drugom svjetskom ratu”, objavljenom 1990. u časopisu Viktimologija, napisanom nakon što je njegova prva knjiga objavljena, uopće ne spominje brojku o „oko 100 tisuća”. Osporavajući tvrdnju dr. Srboljuba Živanovića da je prema nalazima iskopavanja masovnih grobnica 1964. godine u Jasenovcu i na Gradini ustanovljeno da je u Jasenovcu ubijeno 700.000 osoba, Žerjavić u članku zaključuje da bi prema nalazima u masovnim grobnicama „ukupan broj mogao iznositi 40 do 50 tisuća, a ni u kojem slučaju broj od 700 tisuća” ${ }^{10}$ Nezaobilazno je spomenuti da Žerjavić u svojem članku „Gubici stanovništva Jugoslavije u Drugom svjetskom ratu”, objavljenom 1991. u zborniku Političko-geografska i demografska pitanja Hrvatske, koji je sažetak njegove knjige objavljene 1989. godine, ustvrđuje „da je u Jasenovcu i Staroj Gradiški ubijeno oko 92000 ljudi”. ${ }^{11}$ Dakle, ni 40.000 do 50.000 (Jasenovac - Gradina), a ni 92.000 koje Žerjavić spominje ne dovode do zaključka da je riječ o „oko 100 tisuća” žrtava logora Jasenovac. No vratimo se u dane nedugo nakon objavljivanja Žerjavićeve knjige Gubici stanovništva Jugoslavije u drugom svjetskom ratu. Na predstavljanju knjige dr. Milana Bulajića Ustaški

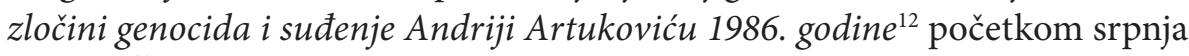
1989. u Židovskoj općini u Zagrebu, na Bulajićeve tvrdnje o broju žrtava u Jasenovcu reagirao je predsjednik Židovske općine Slavko Goldstein i upozorio na neodrživost „megalomanskih” razmjera, pozvao se na Žerjavićeve izračune i njegovu knjigu Gubici stanovništva Jugoslavije u drugom svjetskom ratu i ustvrdio da u „Jasenovcu nije moglo biti ubijeno više od 110 hiljada lju-

\footnotetext{
8 ŽERJAVIĆ, „O stradanjima u Drugom svjetskom ratu: stradali Hrvati od četnika, stradali Srbi i broj stradalih u Jasenovcu”, 571.

9 ŽERJAVIĆ, Opsesije i megalomanije oko Jasenovca i Bleiburga, 43, 69.

10 ŽERJAVIĆ, „Stradanja Jugoslavena u drugom svjetskom ratu”, 47.

11 ŽERJAVIĆ, „Gubici stanovništva Jugoslavije u Drugom svjetskom ratu”, 100.

12 BULAJIĆ, Ustaški zločini genocida i sudenje Andriji Artukoviću 1986. godine.
} 
di”. ${ }^{13}$ - Zanimljivo, na temelju svojega izračuna Žerjavić zaključuje da je riječ o 92.000, a Slavko Goldstein na temelju toga istog izračuna zaključio je da je riječ o 110.000, što moguće objašnjava i kasniji Žerjavićev navod o „oko 100 tisuća”. Ujedno je teško oteti se dojmu da su sve te brojke, Žerjavićeve od 40.000 do $50.000,92.000$ i 100.000 i Goldsteinova od 110.000, pa i one kasnije Žerjavićeve brojke od 83.000 i 85.000 , određene na temelju izračuna zvanoga „odoka”.

\begin{tabular}{|l|l|}
\hline $\begin{array}{l}\text { Vladimir Žerjavić } \\
\text { Izračuni o broju žrtava } \\
\text { logora Jasenovac }\end{array}$ & Broj i nacionalna/etnička struktura žrtava \\
\hline 1989. & - \\
\hline 1990. & Jasenovac - Gradina: $40.000-50.000$ \\
\hline 1991. & oko 92.000 \\
\hline 1992. & oko 100.000 \\
\hline & oko $83.000:$ \\
1992. i 1997. & 45.000 do 52.000 Srba, 13.000 Židova, \\
& 10.000 Roma, 10.000 Hrvata i 2000 Muslimana \\
\hline & $85.000:$ \\
$1993 .-1995$. & 50.000 Srba, 13.000 Židova, \\
& 12.000 Hrvata i Muslimana i 10.000 Roma \\
\hline & oko $85.000:$ \\
1997. i 2001. & 48.000 do 52.000 odnosno 50.000 Srba, \\
& 13.000 Židova, 12.000 Hrvata, 10.000 Roma \\
\hline
\end{tabular}

Žerjavićevi izračuni o broju jasenovačkih žrtava, napose oni o osamdesetak tisuća tijekom 90-ih godina, najučestalije se spominju i prihvaćaju u hrvatskoj historiografiji, i u hrvatskoj javnosti, ponajprije onoj lijevo usmjerenoj, kao „spasonosno” rješenje u ogradi od starih jugoslavenskih komunističkih i obrani od staro-novih srpskih nacionalističkih „megalomanskih” tvrdnji. Zbog načina i mogućnosti utvrđivanja ljudskih gubitaka u Drugome svjetskom ratu Žerjavića su 90-ih godina i osporavali i učestalo napadali ponajprije srpski nacionalisti, ali i neki u Hrvatskoj. Ustvari, jedino je dr. Mihael Sobolevski (Hrvatski institut za povijest, Zagreb), koji je o pitanju i načinu utvrđivanja ljudskih gubitaka Jugoslavije, i Hrvatske, a i žrtava logora Jasenovac, objavio 90-ih godina nekoliko nezaobilaznih članaka ${ }^{14}$ i zastupao poimeničnu

13 Usp. JURIĆ, „Jasenovačke žrtve i uspostava nacionalnog programa u Srbiji (1986. - 1995.)”, 243 i ondje navedena literatura.

14 Usp. SOBOLEVSKI, „Prilog metodologiji istraživanja stvarnih ljudskih gubitaka Hrvatske u tijeku drugoga svjetskog rata”, 203-212; SOBOLEVSKI, „Prešućena istina - žrtve rata na području bivše Jugoslavije 1941.-1945. prema popisu iz 1964. godine”, 87-114 i SOBOLEVSKI, „Između Jasenovca i Bleiburga", 42-47. 
identifikaciju kao utemeljeniju i znanstveno pouzdaniju metodu od izračuna/ procjena, vodio sa Žerjavićem za historiografiju korisnu raspravu. ${ }^{15}$

Neki hrvatski povjesničari bez provjere preuzimaju netočan Žerjavićev navod da Bogoljub Kočović procjenjuje da je u logoru Jasenovac život izgubilo oko 70.000 osoba. ${ }^{16}$ - Zahvaljujući upornom i učestalom ponavljanju ta je netočnost postala „neupitna činjenica” u hrvatskoj historiografiji o logoru Jasenovac te je oduševljeno prihvaćena u lijevo usmjerenoj javnosti kao nedvojbena potvrda točnosti Žerjavićevih izračuna o broju jasenovačkih žrtava. - Tako, primjerice, Nataša Mataušić (Hrvatski povijesni muzej, Zagreb) u svojoj knjizi Jasenovac 1941.-1945. Logor smrti i radni logor (2003.) ustvrđuje da „najtemeljitija istraživanja o broju žrtava u Logoru Jasenovac, sa strogo profesionalnim pristupom i brojnim znanstvenim argumentima, provela su neovisno jedan od drugoga i dva demografa: Hrvat Vladimir Žerjavić i Srbin dr. Bogoljub Kočović. Prema Žerjaviću, u Jasenovcu je najvjerojatnije stradalo oko 83.000 ljudi [...]. Za razliku od Žerjavića, Kočović je došao do procjene da je u Jasenovcu život izgubilo oko 70.000 ljudi”. ${ }^{17}$ Iste navode i tvrdnje iznijela je Mataušić i u svojem članku „Koncentracioni logor Jasenovac”, objavljenom 2006. u zborniku radova Spomen područje Jasenovac, i zatim u svojoj knjizi Koncentracioni logor Jasenovac. Fotomonografija (2008.). ${ }^{18}$ Povjesničar Filip Škiljan u svojoj knjizi Politički zatvorenici u logorima Jasenovac i Stara Gradiška (2009.) piše: „Kočović je, za razliku od Žerjavića došao do brojke od 70.000 ubijenih.” Poziva se na drugo, jugoslavensko izdanje Kočovićeve knjige i, naravno, ne navodi gdje je, na kojoj stranici, to i navedeno, kao što to nije naveo ni Žerjavić. ${ }^{19} \mathrm{U}$ svojem članku „Logorski sustav Jasenovac - kontroverze”, objavljenom iste godine u Zagrebu u zborniku radova Nezavisna Država Hrvatska 1941. - 1945., povjesničar Škiljan pak tvrdi: „Možda su se realnijim brojkama najviše približili statističari Vladimir Žerjavić i Bogoljub Kočović koji su proveli demografska istraživanja početkom devedesetih godina i ustvrdili da je broj žrtava u logorima Jasenovac i Stara Gradiška bio između 70.000 (Kočović) i 83.000 (Žerjavić). Oba su radila nezavisno jedan od drugoga, pa su i njihovi rezultati stoga vjerodostojniji." ${ }^{20}$ - Ali Kočović nikada nije izračunavao niti procjenjivao

\footnotetext{
15 Usp. ŽERJAVIĆ, „Osvrt na napis Mihaela Sobolevskog o popisu žrtava rata 'Prešućena istina - žrtve rata na području bivše Jugoslavije 1941.-1945. prema popisu iz 1964. god.", 123-134; SOBOLEVSKI, „Pogrešno istrčavanje Vladimira Žerjavića”, 351-359 i ŽERJAVIĆ, „Nije pogrešno istrčavanje već razmatranje mogućnosti daljnjeg istraživanja žrtava drugog svjetskog rata", 517-527.

16 ŽERJAVIĆ, Opsesije i megalomanije oko Jasenovca i Bleiburga, 74.

17 MATAUŠIĆ, Jasenovac 1941.-1945., 123.

18 MATAUŠIĆ, „Koncentracioni logor Jasenovac”, 48 i MATAUŠIĆ, Koncentracioni logor Jasenovac. Fotomonografija, 6.

19 ŠKILJAN, Politički zatvorenici u logorima Jasenovac i Stara Gradiška, 204.

20 ŠKILJAN, „Logorski sustav Jasenovac - kontroverze”, 125.
} 
broj žrtava logora Jasenovac. Kočović je samo procijenio mogući ukupan broj srpskih žrtava u logorima Nezavisne Države Hrvatske (NDH). ${ }^{21} \mathrm{Na}$ to sam upozorio u svojim člancima o brojidbenim pokazateljima o ljudskim gubicima Hrvatske u Drugom svjetskom ratu i žrtvama logora Jasenovac u Časopisu za suvremenu povijest 2011. i 2013. godine. ${ }^{22}$ - No neki hrvatski povjesničari ustrajni su u ponavljanju usporedbe Žerjavićeva izračuna i navodnih Kočovićevih procjena o žrtvama logora Jasenovac jer im se uklapa u njihove kalkulacije i tvrdnje, poput prof. dr. Ive Goldsteina. On u knjizi Jasenovac i Bleiburg nisu isto, objavljenoj 2011. u suautorstvu sa Slavkom Goldsteinom, u poglavlju „O broju jasenovačkih i blajburških žrtava” piše, pojednostavnjujući i prilagođavajući svojim tvrdnjama Žerjavićev izračun broja žrtava logora Jasenovac od 83.000 odnosno 85.000 na „oko 80.000 do 90.000 ljudi”, samozadovoljno ustvrđuje: „Dr. Bogoljub Kočović je istovremeno (potkraj osamdesetih godina), nezavisno od Žerjavića, obavio statističko-demografsko istraživanje i došao do približno sličnih rezultata, odnosno da je u Jasenovcu život izgubilo oko 70.000 ljudi. Novim znanstvenim i stručnim istraživanjima Žerjavićeve i Kočovićeve procjene o broju jasenovačkih žrtava u proteklih dvadeset godina nisu dovedene u pitanje. Naprotiv, one se novim istraživanjima sve više potvrđuju.” ${ }^{23}$ Prilagođavanje Žerjavićeva izračuna („ubijeno oko 80.000 do 90.000 ljudi") ponavlja Ivo Goldstein i u knjizi Jasenovac. Tragika, mitomanija, istina u suautorstvu sa Slavkom Goldsteinom, objavljenoj 2016., a u vezi s navodnim Kočovićevim procjenama i sličnostima s Žerjavićevim izračunima o broju jasenovačkih žrtava Ivo Goldstein je skrupulozniji: „Srpski statističar dr. Bogoljub Kočović, koji je živio u Parizu, potkraj osamdesetih godina, neovisno od Žerjavića, obavio je statističko-demografsko istraživanje i došao do približno sličnih rezultata - da je u logorima NDH život izgubilo između 150 i 200.000 Srba, što je navelo kasnije Žerjavića da (prilično logično) zaključi kako bi Kočović procijenio da je u Jasenovcu stradalo oko 70.000 ljudi." ${ }^{24}$ I u svojoj kapitalnoj knjizi Jasenovac, objavljenoj 2018. u Zagrebu, zatim 2019. i u Novom Sadu, ponavlja priču i navodi da je Kočović ${ }^{25}$ došao do procjene da je u logorima u NDH život izgubilo između 150.000 i 200.000 Srba, „što je navelo

\footnotetext{
${ }_{21}$ Usp. KOČOVIĆ, Žrtve Drugog svetskog rata u Jugoslaviji (1990.), XVI i KOČOVIĆ, Nauka, nacionalizam i propaganda, 87-88, 147-148.

22 Usp. GEIGER, „Ljudski gubici Hrvatske u Drugom svjetskom ratu koje su prouzročili 'okupatori i njihovi pomagači'. Brojidbeni pokazatelji”, 729 i GEIGER, „Brojidbeni pokazatelji o žrtvama logora Jasenovac, 1941.-1945., 230-231.

23 I. GOLDSTEIN, „O broju jasenovačkih i blajburških žrtava”, 312.

24 I. GOLDSTEIN, „O broju žrtava jasenovačkog logorskog kompleksa”, 120.

25 KOČOVIĆ, Žrtve Drugog svetskog rata u Jugoslaviji (1985.).
} 
kasnije Žerjavića ${ }^{26}$ da (prilično logično) zaključi kako bi Kočović procijenio da je u Jasenovcu stradalo oko 70.000 ljudi" ${ }^{27}$

Usput, dvije napomene: Kočović nije proveo svoja „demografska istraživanja početkom devedesetih godina”, kako piše Škiljan, a ni „potkraj osamdesetih godina”, kako piše Ivo Goldstein. Da su uzeli u ruke Kočovićeve knjige, a ne pisali napamet, bilo bi im jasno da je prvo izdanje Kočovićeve knjige Žrtve Drugog svetskog rata u Jugoslaviji objavljeno 1985. u Londonu, a drugo, jugoslavensko izdanje u Sarajevu 1990. godine. Postoji i treće izdanje te knjige, ali ne gajim iluzije da im je poznato. Mataušić u svojoj knjizi Jasenovac 1941.-1945. Logor smrti i radni logor znalački napominje da je drugo izdanje Kočovićeve knjige Žrtve Drugog svetskog rata u Jugoslaviji, objavljeno u Sarajevu 1990., „prijevod izdanja objavljenog na engleskom jeziku u Londonu 1985.”28 Da je kojim slučajem uzela u ruke prvo izdanje Kočovićeve knjige, a ne pisala napamet, znala bi da je knjiga objavljena na srpskome jeziku.

Ivo Goldstein - kao i neki drugi hrvatski povjesničari „stručnjaci” za logor Jasenovac, koji bez provjere preuzimaju netočan Žerjavićev navod - ustvari se nije konzultirao s Kočovićem, koji 1990. u „Uvodu u jugoslovensko izdanje” svoje knjige Žrtve Drugog svetskog rata u Jugoslaviji jasno piše: „Velika je rasprava nastala povodom broja žrtava u ustaškom logoru u Jasenovcu. I tu je moja studija bila navođena u mnogim raspravama, štampi ili na televiziji, iako nisam uopšte izračunavao te žrtve. U više navrata sam javno izjavio da nisam u mogućnosti da kažem koliki je broj ubijenih Srba u Jasenovcu, kao što ne znam broj ubijenih u Blajburgu.” ${ }^{29}$ - „Rekao sam da ne znam koliko je bilo žrtava u Jasenovcu”, ponovio je Kočović i uz tablicu svojih izračuna/procjena o ljudskim gubicima Srba na području NDH. ${ }^{30}$ Žerjavić, očito u snažnoj želji da potvrdi svoje izračune, iz te je tablice izvukao zaključak o tome što je Kočović procijenio o Jasenovcu. Usto Kočović i u svojoj knjizi Nauka, nacionalizam i propaganda, objavljenoj 1999. u Parizu, naglašava: „Ja sam redovno odbijao da se upuštam u diskusije o broju ubijenih u Jasenovcu [...]. Iako i dalje tvrdim da sam siguran da taj broj nije 700.000 i više [...] ako već treba dati neku cifru, rekao bih da taj broj za Srbe može da bude između 150.000 i 200.000, ali sam odmah dodao da nemam dokaza za tu tvrdnju. Docnije sam precizirao da sam tim brojem obuhvatio sve logore smrti u NDH [...] te da moja gore navedena cifra obuhvata ukupan broj žrtava u svim logorima na teritoriji NDH." ${ }^{31}$ - Pi-

\footnotetext{
ŽERJAVIĆ, Opsesije i megalomanije oko Jasenovca i Bleiburga, 74.

I. GOLDSTEIN, Jasenovac (2018.), 788-789 ili I. GOLDSTEIN, Jasenovac (2019.), 788-789.

MATAUŠIĆ, Jasenovac 1941.-1945., 123.

KOČOVIĆ, Žrtve Drugog svetskog rata u Jugoslaviji (1990.), XVI.

Isto, XVIII.

KOČOVIĆ, Nauka, nacionalizam i propaganda, 147-148.
} 
sao sam već i upozoravao ${ }^{32}$, a ponavljam i ovdje: Kočović dakle procjenjuje da broj Srba koji su izgubili život u svim logorima NDH „može da bude” između 150.000 i 200.000 i, što je iznimno važno, napominje „nemam dokaza za tu tvrdnju”. Pa ako Kočović kazuje da njegova brojka „može da bude” i da „ne$\mathrm{ma}[\mathrm{m}]$ dokaza za tu tvrdnju”, nije jasno na temelju čega Ivo Goldstein tvrdi da je Žerjavić „prilično logično” zaključio da bi Kočović procijenio da je u Jasenovcu stradalo oko 70.000 ljudi. Da je to „prilično logično”, Kočović, koji je „redovno odbijao da se upušta u diskusije o broju ubijenih u Jasenovcu”, tako bi - logično je - i procijenio. No prilično je nelogično, kao što je nelogično da Goldstein - i drugi ovdje spomenuti, a i nespomenuti, hrvatski povjesničari nije imao potrebu provjeriti što točno misli i piše Kočović.

Kočović i Žerjavić neizmjerno su zaslužni za rušenje mita o 1.700 .000 ljudskih gubitaka Jugoslavije u Drugome svjetskom ratu, a time i znatno pretjeranih navoda o razmjerima ljudskih gubitaka u NDH i žrtava logora Jasenovac. U historiografiji su kao takvi i zabilježeni. Kočović se nije upuštao u izračunavanje/procjenjivanje broja žrtava logora Jasenovac, kao ni Bleiburga. Žerjavić je pak upao u zamku prevelikih htijenja i očekivanja oko brojeva žrtava i Jasenovca i Bleiburga, a to statističkom metodom i(li) procjenama, primjenom „standardne statističke metode i metode sabiranja podataka iz literature” koju je koristio, nije moguće valjano riješiti.

Javna ustanova Spomen-područje Jasenovac (JUSP Jasenovac) objavila je 2007. Poimenični popis žrtava koncentracijskog logora Jasenovac 1941.-1945., koji donosi podatke za 72.193 osobe. Prema tom popisu, najviše je žrtava Srba (40.251), zatim Roma (14.750), Židova (11.723) i Hrvata (3563). ${ }^{33}$ Nekoliko godina poslije, 2013., JUSP Jasenovac na svojim mrežnim stranicama objavio je novi, revidirani i dopunjeni popis, koji donosi podatke za 83.145 osoba koje su život izgubile u logorima Jasenovac i Stara Gradiška. Prema tom popisu, najviše je žrtava Srba (47.627), zatim Roma (16.173), Židova (13.116) i Hrvata (4255), a popisano je i 20.101 dijete kao logorska žrtva. ${ }^{34}$ Naravno, s revizijom i dopunama popisa jasenovačkih žrtava u JUSP-u Jasenovac se nastavilo, pa se broj osoba koje su izgubile život u logoru Jasenovac i Stara Gradiška i dalje polako, ali nezadrživo povećava.

\footnotetext{
32 Usp. GEIGER, „Ivo Goldstein, Jasenovac (Zaprešić; Jasenovac: Fraktura; Javna ustanova Spomen-područje Jasenovac, 2018)”, 302-303.

33 Usp. Poimenični popis žrtava koncentracijskog logora Jasenovac 1941.-1945.

34 Usp. „Poimenični popis žrtava KCL Jasenovac 1941-1945.”
} 
Žrtve logora Jasenovac i Stara Gradiška, nacionalna/etnička i spolna struktura prema popisu JUSP-a Jasenovac, 2013.

\begin{tabular}{|l|r|r|r|r|}
\hline & \multicolumn{1}{|c|}{ Muškarci } & \multicolumn{1}{c|}{ Žene } & \multicolumn{1}{c|}{ Djeca } & \multicolumn{1}{c|}{ Ukupno } \\
\hline Srbi & 21.738 & 13.206 & 12.683 & 47.627 \\
\hline Romi & 5688 & 4877 & 5608 & 16.173 \\
\hline Židovi & 7762 & 3753 & 1601 & 13.116 \\
\hline Hrvati & 2866 & 1249 & 140 & 4255 \\
\hline Muslimani & 897 & 179 & 52 & 1128 \\
\hline Ostali i nepoznato & $539+80$ & $137+73$ & $15+2$ & $691+155$ \\
\hline Ukupno & 39.570 & 23.474 & 20.101 & 83.145 \\
\hline
\end{tabular}

Priređivači Poimeničnoga popisa žrtava koncentracijskog logora Jasenovac 1941.-1945., kustosi JUSP-a Jasenovac, u objašnjenju nastanka toga popisa naveli su sljedeće: „Iz dosad najobimnijeg popisa Drugog svjetskog rata na području bivše Jugoslavije, 'Poimeničnog popisa Drugog svjetskog rata u Jugoslaviji' (597.323 žrtve), koji je na osnovu imeničnog popisa žrtava Zemaljske komisije za utvrđivanje zločina okupatora i njihovih pomagača iz 1946. te prikupljenih dodatnih podataka SUBNOR-a o žrtvama rata, 1964. sačinio Savezni zavod za statistiku SFRJ, izdvojili smo imena svih osoba kojima su kao mjesto stradanja navedeni logori i stratišta iz sistema KL Jasenovac. Koristeći više stotina različitih izvora (knjiga, dokumenata, fotografija, izjava rodbine i prijatelja jasenovačkih žrtava, terenskih istraživanja i fotografiranja spomenika žrtava fašističkog terora), [...] uspoređivanjem i kritičkim preispitivanjem podataka za svaku žrtvu ponaosob, sačinjen je popis djece, muškaraca i žena ubijenih u KL Jasenovac." 35 - Nisam uvjeren da su kustosi JUSP-a Jasenovac pročitali Uputstvo za izvršenje popisa iz 1964. Saveznoga izvršnog vijeća (SIV) SFR Jugoslavije, Komisije za popis žrtava rata $1941-1945 .{ }^{36}$, a ni izvještaj Žrtve rata 1941-1945. godine. (Rezultati popisa) iz 1966. Saveznoga zavoda za statistiku, kao ni dodatni „Izveštaj o izvršenom popisu žrtava rata 1941-1945. godine” Komisije za popis žrtava rata 1941-1945. ${ }^{37}$ - Ako pak jesu, trebalo bi im biti jasno na temelju čega je i kako napravljen popis ljudskih gubitaka Jugoslavije u Drugome svjetskom ratu 1964. godine. - Pitanje je i što su to oni iz popisa iz 1964. izdvojili jer postoji separat toga popisa za logore Jasenovac i Stara Gradiška, koji je 1992. umnožio Savezni zavod za statistiku Savezne Republike Jugoslavije pod naslovom Spisak žrtava rata 1941-1945. Ustaški lo-

35 Usp. MIHOVILOVIĆ, SMREKA, „O poimeničnom popisu žrtava KL Jasenovac prema do sada prikupljenim i provjerenim podacima”, 218 i Poimenični popis žrtava koncentracijskog logora Jasenovac 1941.-1945., 8.

36 Popis žrtava rata 1941-1945. III. Uputstvo za izvršenje popisa.

37 Žrtve rata 1941-1945. godine. (Rezultati popisa). 
gor Jasenovac ${ }^{38}$, a koji je zatim 1998. objavio Bošnjački institut pod naslovom Jasenovac. Žrtve rata prema podacima Statističkog zavoda Jugoslavije ${ }^{39}$, i koji donosi podatke za nešto više od 59 tisuća žrtava. - Pišu da su koristili „više stotina različitih izvora (knjiga, dokumenata, fotografija, izjava rodbine i prijatelja jasenovačkih žrtava, terenskih istraživanja i fotografiranja spomenika žrtava fašističkog terora)". U odnosu na popis iz 1964., revizijom i dopunom JUSP-a Jasenovac broj žrtava povećan je 2007. godine za 13.005, odnosno nešto manje od 22 \%, a 2013. godine za 23.957, odnosno za više od 40 \%. - Postavlja se pitanje: koliko je tih žrtava pronađeno u izvornim dokumentima NDH, odnosno koliko su o mjestu smrti neke osobe pouzdani poslijeratni izvještaji različitih komisija, navodi u knjigama i na spomenicima? Kako su i jesu li, kako tvrde „uspoređivanjem i kritičkim preispitivanjem podataka za svaku žrtvu ponaosob", sve te navode, kao i izjave rodbine i prijatelja žrtava, provjerili i uopće mogli provjeriti kao vjerodostojne? - Daleko bi nas odvelo nabrajanje mnogobrojnih primjedbi popisu jasenovačkih žrtava JUSP-a Jasenovac te spominjem jedan ogledni primjer i jedan nezanemariv problem. - Mr. Branko Kranjčev i Josip Ćurković, koje se nažalost ne može proglasiti nacionalistima ili „revizionistima” i nestručnima, koristeći dostupnu dokumentaciju i literaturu, propitali su točnost navoda Poimeničnoga popisa žrtava koncentracijskog logora Jasenovac 1941.-1945. JUSP-a Jasenovac za Židove Našica i našičkoga kraja, prema kojem je u logorima Jasenovac i Stara Gradiška život izgubilo njih 177. Kranjčev i Ćurković sustavnom su analizom podataka toga popisa među ostalim utvrdili: „,̌etiri osobe evidentirane su u Popisu žrtava dvaput”, „jedanaest osoba valja brisati s Popisa jer nisu smrtno stradale u Jasenovcu” i „za dvije osobe s Popisa [...] nema pouzdanih podataka o njihovoj sudbini pa bi ih zasad trebalo izostaviti s popisa jasenovačkih žrtava." ${ }^{\prime 40}$ Dakle, postotak nedvojbenih netočnosti iznosi $9,6 \%$ te je očito da nije riječ o pojedinačnim ili malim propustima. - Postavlja se pitanje: ako je Poimenični popis žrtava koncentracijskog logora Jasenovac 1941.-1945. rezultat višegodišnjega istraživanja, kako to da i nakon takvih istraživanja, „uspoređivanjem i kritičkim preispitivanjem podataka za svaku žrtvu ponaosob", nisu uočene i ispravljene takve netočnosti? - Upozorenje na oprez prema popisu jasenovačkih žrtava JUSP-a Jasenovac razotkrila je izložba Ako tebe zaboravim... Holokaust u Hrvatskoj 1941. - 1945. / zadnje odredište Auschwitz, postavljena u Zagrebu početkom veljače 2020., i potvrdila da nisu provjereni dokumenti i popisi koji su neizostavno trebali biti uspoređeni s podacima JUSP-a Jasenovac. Dokumentima iz Državnoga muzeja Auschwitz-Birkenau u Oświęcimu na izložbi je nedvojbeno

\footnotetext{
38 Usp. Spisak žrtava rata 1941-1945. Ustaški logor Jasenovac.

39 Usp. Jasenovac. Žrtve rata prema podacima Statističkog zavoda Jugoslavije.

40 Usp. KRANJČEV, ĆURKOVIĆ, „Poimenični popis Židova, žrtava koncentracijskog logora Jasenovac 1941.-1945. po naseljima općine Našice”, 236-254.
} 
potvrđeno da su na popisu žrtava logora Jasenovac JUSP-a Jasenovac i osobe koje su život izgubile u KZ Auschwitz. ${ }^{41}$ - Ako je popis JUSP-a Jasenovac rezultat višegodišnjega istraživanja, „uspoređivanjem i kritičkim preispitivanjem podataka za svaku žrtvu ponaosob”, kako to da nisu uspoređeni popisi Jasenovca i Auschwitza? Postavlja se i pitanje je li trebalo provjeriti nalaze li se kojim slučajem na Poimeničnom popisu žrtava koncentracijskog logora Jasenovac 1941.-1945. i osobe koje su život izgubile u nekom od logora Njemačkoga Reicha, ili to nije potrebno učiniti?

Hrvatski udžbenici povijesti od osamostaljenja Hrvatske do danas navode različite brojke o žrtvama logora Jasenovac: u logorima NDH, „od kojih je najzloglasniji bio u Jasenovcu”, „život [je] izgubilo više desetaka tisuća ljudi raznih nacionalnosti. Točan broj nije poznat”42 i „Najveći logori smrti bili su u Jasenovcu i Staroj Gradiški. U njima su stradali deseci i deseci tisuća ljudi"43 do najčešće brojidbenih pokazatelja poimeničnoga popisa JUSP-a Jasenovac (72.000 odnosno 83.000) $)^{44}$, ali i da je prema procjenama u Jasenovcu „ubijeno i pomrlo od bolesti, gladi, hladnoće i zlostavljanja između 80000 i 100000 ljudi". ${ }^{45}$ U Hrvatskoj su Žerjavićevi izračuni/procjene o 83.000 i strukturi žrtava logora Jasenovac te pokazatelji poimeničnoga popisa JUSP-a Jasenovac o jasenovačkim žrtvama, kao i procjena „odoka” od 100.000 žrtava, postali i enciklopedijskom činjenicom. ${ }^{46}$

Primjetno je u Hrvatskoj da oni kojima se brojke poimeničnih popisa žrtava logora Jasenovac čine premalima navode odoka da je u Jasenovcu život izgubilo do 100.000 osoba. Objašnjenja hrvatskih povjesničara o utemeljenosti brojke od 80.000 do 100.000 žrtava logora Jasenovac ponekad su i zanimljiva. - Tako Mataušić, uz navođenje upitnoga Žerjavićeva izračuna i nepostojeće Kočovićeve procjene te i po mnogočemu upitnog poimeničnog popisa JUSP-a Jasenovac, spominje i poimenični popis logora Jasenovac iz 1964. godine, kojim je utvrđeno 59.188 žrtava. „Naknadne su provjere utvrdile da popis ima čitav niz nedostataka te da navedenu brojku treba uvećati za barem $40 \%$. Prema tako uvećanoj procjeni u KL Jasenovac s logorom Stara Gradiška stradalo je od

\footnotetext{
${ }^{41}$ Usp. VUKIĆ, „Cirkus sa žrtvama nastavlja se jer su u laži kratke noge. Plenković otvorio tragikomičnu izložbu o holokaustu, Jasenovcu...”, 24-26 i GEIGER, „Nedostatno znanje, nestručnost i šlamperaj ili još jednom o izložbi Ako tebe zaboravim... Holokaust u Hrvatskoj 1941. - 1945. I zadnje odredište Auschwitz", 345.

$42 \quad$ KOREN, Povijest 8. Udžbenik za 8. razred osnovne škole (2003.), 141.

43 Ves. ĐURIĆ, Povijest 8. Udžbenik za osmi razred osnovne škole, 90.

44 Usp. primjerice: AKMADŽA, JAREB, RADELIĆ, Povijest 4. Udžbenik za 4. razred gimnazije, 120; Ves. ĐURIĆ, Vremeplov 8. Udžbenik povijesti za osmi razred osnovne škole, 133; ERDELJA, STOJAKOVIĆ, Tragom prošlosti 8. Udžbenik povijesti u osmom razredu osnovne škole, 120 i BEKAVAC, JAREB, Povijest 8. Udžbenik za osmi razred osnovne škole, 85.

45 Usp. primjerice: KOREN, Povijest 8. Udžbenik povijesti za 8. razred osnovne škole, 169.

46 Usp. „Koncentracijski logori”, 85.
} 
80.000 do 100.000 ljudi”, ustvrđuje Mataušić. ${ }^{47}$ Naknadne provjere - čega? Popisa jasenovačkih žrtava iz 1964. godine? Gdje to piše? U izvještaju Žrtve rata 1941-1945. godine. (Rezultati popisa) Saveznoga zavoda za statistiku iz 1966. godine? Nisam uvjeren da je Mataušić pročitala i dodatni „Izveštaj o izvršenom popisu žrtava rata 1941-1945. godine" Savezne komisije za popis žrtava rata 1941-1945. - U tim izvještajima jasno piše da je popisom ljudskih gubitaka Jugoslavije obuhvaćeno oko 56 do 59 \% ili pak 60 do $65 \%$ osoba od onih koje je prema njihovoj procjeni trebalo popisati. ${ }^{48}$ No ona mudro zaključuje da je prema „barem 40 \%” uvećanom broju popisanih žrtava logora Jasenovac i Stara Gradiška stradalo od 80.000 do 100.000 osoba. - Ali „barem 40 \%” od broja popisanih nije isto što i 56 do $59 \%$ ili pak 60 do $65 \%$ od onih koje je navodno trebalo popisati. - A što će povjesničarima matematika!

Najuporniji u promicanju brojke od 100.000 žrtava (može i nešto manje, ali bolje više) logora Jasenovac niz su godina Slavko Goldstein i Ivo Goldstein. ${ }^{49}$ Stoga je u hrvatskim antifašističkim krugovima brojka od 100.000 žrtava logora Jasenovac i prihvaćena, iako je riječ o prvotnoj Žerjavićevoj procjeni bez sustavnih istraživanja i bez potvrda u izvorima, koju su Goldsteini preuzeli, naglašavali i dalje uporno ponavljali. - Kako su Goldsteinove procjene broja jasenovačkih žrtava oko 100.000, po svaku cijenu treba osnažiti i potvrditi točnost Žerjavićevih izračuna odnosno procjena i zanemariti i što više umanjiti mnogobrojne prigovore na manjkavosti poimeničnoga popisa JUSP-a Jasenovac od nešto više od 83.000. I propitivanju broja jasenovačkih žrtava valjda bi trebao biti kraj. Ivo Goldstein uporno u javnosti iznosi mišljenje da se o logoru Jasenovac „istina manje-više zna, uključujući i približan broj žrtava”. ${ }^{50}$ Goldstein štoviše ustvrđuje da se „u krugovima skrupuloznih istraživača računa da je poimenični popis uglavnom dogotovljen u trenutku kada je na njemu zabilježeno 90 do $95 \%$ pretpostavljenih žrtava. Danas smo praktički došli do tog stadija u istraživanju ili ćemo do njega doći u slijedećih nekoliko godina. Tako bi se konačno mogla zaključiti mučna diskusija o broju jasenovačkih žrtava" ${ }^{51}$ - A Ivo Goldstein trebao bi, naravno, biti taj tko će određivati koliki je „pretpostavljeni” broj jasenovačkih žrtava i što je „istina” o Jasenovcu, a što nije.

\footnotetext{
47 MATAUŠIĆ, „Koncentracioni logor Jasenovac”, 47 i MATAUŠIĆ, Koncentracioni logor Jasenovac. Fotomonografija, 6.

48 Usp. Žrtve rata 1941-1945. godine. (Rezultati popisa), 5-7 i dodatni „Izveštaj o izvršenom popisu žrtava rata 1941-1945.", VII-XV.

49 Usp. S. GOLDSTEIN i I. GOLDSTEIN, Jasenovac i Bleiburg nisu isto i S. GOLDSTEIN i I. GOLDSTEIN, Jasenovac. Tragika, mitomanija, istina.

50 I. GOLDSTEIN, „Komisija za Jasenovac: nova besmislena inicijativa šefice države”.

51 I. GOLDSTEIN, „O broju jasenovačkih i blajburških žrtava”, 313-314; I. GOLDSTEIN, „O broju žrtava jasenovačkog logorskog kompleksa”, 127; I. GOLDSTEIN, Jasenovac (2018.), 797 ili I. GOLDSTEIN, Jasenovac (2019.), 797.
} 
Žerjavić je u svim svojim izračunima navodio da je broj Židova žrtava logora Jasenovac 13.000, pa i u svojem članku „Demografski pokazatelji o stradanju Židova u NDH”, objavljenom 1996. u zborniku Antisemitizam, holokaust, antifašizam u izdanju Židovske općine Zagreb, koji je objavljen i 1997. u prijevodu toga zbornika na engleski jezik. ${ }^{52}$ Ali Ivo Goldstein Žerjavićev izračun, kao i većinu drugih izračuna, procjena i poimeničnih popisa, drži netočnim i premalim te „odoka” prejednostavnim izračunom/procjenom u nizu svojih članaka i knjiga posljednjih desetak godina uporno zaključuje da je u logoru Jasenovac bilo između 16.000 i 18.000 odnosno oko 17.000 i 17.000 do 18.000 žrtava. ${ }^{53}$ Svjetonazorski istomišljenici i sljedbenici Ive Goldsteina preuzeli su bespogovorno njegove „korekcije” Žerjavićeva broja žrtava Židova u logoru Jasenovac kao utvrđenu činjenicu. - Nataša Mataušić u svojoj knjizi Jasenovac 1941.-1945. Logor smrti i radni logor uz Žerjavićeve brojke i procjene nacionalne/etničke strukture žrtava logora Jasenovac napominje da su Goldsteini u svojoj knjizi Holokaust u Zagrebu (2001.) donijeli „,dopunu broja stradalih Židova u jasenovačkim logorima, koji se prosuđuje na 'vrlo blizu 17.000 žrtava [...]"”. ${ }^{54}$ Mišo Deverić i mr. Ivan Fumić u knjizi Hrvatska u logorima 1941.-1945., objavljenoj 2008. u izdanju Saveza antifašističkih boraca i antifašista Republike Hrvatske, navode da je u Jasenovcu „pogubljeno između 80.000 i 100.000 ljudi, od kojih su od 45 do 52 tisuće bili Srbi, oko 17.000 Židova, blizu 10.000 Roma i najmanje 10.000 Hrvata, među kojima su ubrojeni i Muslimani-Bošnjaci” ${ }^{55}$ Bilo bi neobično da Goldsteinove „korekcije” Žerjavićevih izračuna nisu ušle u hrvatske udžbenike povijesti, pa Snježana Koren u svojem Udžbeniku za 8. razred osnovne škole (2007.) piše: „Smatra se da je u logoru stradalo oko 45-52.000 Srba, 17.000 Židova, 10.000 Roma te 10.000 političkih protivnika režima, ponajviše Hrvata i Bošnjaka." ${ }^{56}$ - Propitivanje točnosti Žerjavićevih izračuna/procjena broja i strukture žrtava logora Jasenovac i vjerodostojnosti poimeničnoga popisa JUSP-a Jasenovac, kao i drukčija mišljenja, u Hrvatskoj su najobičniji „revizionizam”. Naravno, ako to ne čine Ivo Goldstein i njegovi istomišljenici.

\footnotetext{
52 Usp. ŽERJAVIĆ, „Demografski pokazatelji o stradanju Židova u NDH”, 136 ili ŽERJAVIĆ „Demographic Indicators of the Jewish Ordeal in the Independent State of Croatia”, 76.

53 Usp. primjerice: I. GOLDSTEIN, S. GOLDSTEIN, Holokaust u Zagrebu, 647-648; I. GOLDSTEIN, „Istraživanje židovskih žrtava: razmatranja o Zagrebu i Hrvatskoj”, 461; I. GOLDSTEIN, „Genocid nad Židovima u Nezavisnoj Državi Hrvatskoj”, 45; I. GOLDSTEIN, „Židovi u logoru Jasenovac”, 138; I. GOLDSTEIN, „O broju jasenovačkih i blajburških žrtava”, 211; I. GOLDSTEIN, „O broju žrtava jasenovačkog logorskog kompleksa”, 125 i I. GOLDSTEIN, Jasenovac (2018.), 775, 790 ili I. GOLDSTEIN, Jasenovac (2019.), 775, 790.

54 MATAUŠIĆ, Jasenovac 1941.-1945., 123.

55 DEVERIĆ, FUMIĆ, Hrvatska u logorima 1941.-1945., 126.

56 KOREN, Povijest 8. Udžbenik za 8. razred osnovne škole (2007.), 126.
} 
Ivo Goldstein u svojoj knjizi Jasenovac, i u hrvatskom izdanju 2018. i u srpskom izdanju 2019., ustvrđuje: „Velika većina od oko 120.000 do 130.000 ljudi koji su ušli u jasenovački logorski sustav nije izašla živa. Ubijeno je ili je umrlo od mučenja, bolesti i gladi oko 90.000 zatočenika." ${ }^{57}$ Kako je Goldstein došao do broja od „oko 120.000 do 130.000 ljudi koji su ušli u jasenovački logorski sustav”? - Jednostavno, u bilješci se poziva na: „Motl - Mihovilović, Zaboravljeni, 13-14” (radi se o „Predgovoru” Filipa Škiljana u toj knjizi ${ }^{58}$ ), ali na tim stranicama, a ni drugdje u toj knjizi, nema spomena brojki od 120 do 130 tisuća. - Zanimljivo je Goldsteinovo izmišljanje i odoka navođenje jasenovačkih brojki. No tu nije kraj. Ivo Goldstein u svojoj knjizi Kontroverze iz hrvatske povijesti 20. stoljeća, objavljenoj potkraj 2019., u poglavlju „Jasenovac - radni logor ili logor smrti?” ponavlja: „Ubijeno je ili je umrlo od mučenja, bolesti i gladi oko 90.000 zatočenika.” Ali navodi i: „Od oko 130 do 150 tisuća ljudi, koji su za vrijeme postojanja jasenovačkih logora u njih ušli, u velikoj većini iz njih živi nisu izišli." ${ }^{99}$ Goldstein ne objašnjava kako je od „oko 120.000 do 130.000 ljudi koji su ušli u jasenovački logorski sustav” u svojoj knjizi Jasenovac došao do „oko 130 do 150 tisuća ljudi, koji su za vrijeme postojanja jasenovačkih logora u njih ušli”. Deset-dvadeset tisuća manje ili više, koga briga, važno je da skrupulozni Ivo Goldstein iskazuje svoj matematički genij. - I usput pitanje: Ivo, gdje je drobilica?

Na predstavljanju srbijanskoga izdanja knjige Jasenovac u Beogradu 4. travnja 2019. Ivo Goldstein spomenuo je da je poimeničnim popisom u JUSP-u Jasenovac utvrđeno 83.000 žrtava logora Jasenovac. Prema pisanju dnevnoga lista Politika, Goldstein je zatim naglasio: „Naravno nakon obimnog istraživanja shvatio sam da na taj broj treba dodati 10 ili 20 odsto nestalih ili nepopisanih žrtava. Verujem da je u Jasenovcu stradalo oko 120.000 ljudi i da bi se na nekoj stručnoj konferenciji sa tim složile i moje kolege istoričari u Beogradu."60 No vratimo se u pučku školu: $10 \%$ od 83.000 iznosi 8300, a $20 \% 16.600$, pa nije jasno kojom je to matematičkom operacijom Ivo Goldstein došao do brojke od 120.000. Usto, zagonetno je na temelju kojih je pokazatelja Goldstein zaključio da brojci od 83.000 treba dodati 10 ili $20 \%$ ? - Zašto ne $3 \%$ ili pak $500 \%$ ? Ili je riječ o unaprijed zadanom broju?

Pišem ove retke u nelagodi i velikom strahu jer svako propitivanje utemeljenosti i točnosti Žerjavićevih izračuna/procjena, vjerodostojnosti poimeničnoga popisa JUSP-a Jasenovac i točnosti genijalnih Goldsteinovih izračuna/procjena broja i strukture jasenovačkih žrtava, kao i propitivanje znanja i

\footnotetext{
I. GOLDSTEIN, Jasenovac (2018.), 26 ili I. GOLDSTEIN, Jasenovac (2019.), 26.

Usp. MOTL, MIHOVILOVIĆ, Zaboravljeni. Knjiga o posljednjim jasenovačkim logorašima. I. GOLDSTEIN, Kontroverze iz hrvatske povijesti 20. stoljeća, 97.

„Goldštajn [Ivo]: U Jasenovcu je stradalo oko 120.000 ljudi”.
} 
sposobnosti njegovih istomišljenika i sljedbenika, u Hrvatskoj se proglašava „revizionizmom” i podilaženjem „ustašoidima”.

„Umanjivači” broja žrtava logora Jasenovac u Republici Hrvatskoj nakon raspada SFR Jugoslavije

U Hrvatskoj su tijekom 90-ih godina Žerjavićevi izračuni/procjene o nešto više od 80.000 jasenovačkih žrtava u historiografiji i publicistici bili prevladavajući, pa i u javnosti „općeprihvaćeni”. No kao odgovor na stare jugoslavenske i staro-nove srbijanske interpretacije zločina počinjenih u NDH, a napose o broju žrtava logora Jasenovac, oglasili su se mnogobrojni znanstveno više ili manje utemeljeni, ali i „revizionistički” nastrojeni osporavatelji genocidnosti Hrvata i ,jasenovačkoga mita”. - Mr. Kazimir Katalinić, istaknuti hrvatski emigrant iz Argentine, predsjednik Hrvatske republikanske zajednice, autor nekoliko rasprava o ljudskim gubicima Hrvata u Drugome svjetskom ratu, u svojoj knjizi Argumenti. NDH, BiH, Bleiburg i genocid (Buenos Aires - Zagreb, 1993.), u osvrtu na Žerjavićevu knjigu Gubici stanovništva Jugoslavije u drugom svjetskom ratu primjećuje: „Tako u pogledu broja ubijenih u Jasenovcu i Staroj Gradiški [Slavko] Goldstein [u uvodnom dijelu u svojim uredničkim napomenama] ističe da je ‘Žerjavić dao okvire, koji jasno pokazuju da su procjene o 700.000 žrtava daleko pretjerane, ali da su neodržive minimalizacije koje govore o 40.000 žrtava.” Katalinić ustvrđuje: „Dakle, trebalo je u knjizi postaviti takve 'okvire', koji će srušiti mit o 700.000 žrtava, ali izbjeći 'minimalizaciju’ žrtava, bez obzira da li se radi o minimalizaciji ili o povijesnoj istini." ${ }^{11}$ I povjesničar Josip Jurčević u svojoj knjizi Nastanak jasenovačkog mita, objavljenoj 1998. (radi se o magistarskom radu obranjenom 1996.), u pitanju broja jasenovačkih žrtava, u osporavanju srpske „pogibeljomanije” i „megalomanskih" navoda i tvrdnji, a i Žerjavićevih izračuna/procjena toga broja, priklanja se zaključku dr. Franje Tuđmana u knjizi Bespuća povijesne zbiljnosti ${ }^{62}$ da je riječ o „nekoliko (vjerojatno 3-4) desetaka tisuća zatočenika”. ${ }^{63}$ Prof. dr. Josip Pečarić u svojoj „knjizi na knjigu” Srpski mit o Jasenovcu (1998. i 2000.), opsežnom osvrtu na pisanja dr. Milana Bulajića, posebno na njegovu knjigu Jasenovački mit Franje Tudmana - Genocid nad Srbima, Jevrejima i Cigani-

\footnotetext{
61 KATALINIĆ, Argumenti. NDH, BiH, Bleiburg i genocid, 144-145.

62 TUĐMAN, Bespuća povijesne zbiljnosti.

63 Usp. JURČEVIĆ, Nastanak jasenovačkog mita, 152-153, 166. Jurčević isto navodi i u izdanju knjige na njemačkom jeziku objavljenom u Zagrebu 2007. godine: Die Entstehung des Mythos Jasenovac. Probleme bei der Forschungsarbeit zu den Opfern des II. Weltkrieges auf dem Gebiet von Kroatien.
} 
$m a,{ }^{64}$ i u osporavanju njegovih navoda o ustaškim zločinima u NDH i broju jasenovačkih žrtava, i napada na pisanja dr. Tuđmana o ljudskim gubicima u NDH, pozivao se i na Kočovićeve i Žerjavićeve izračune/procjene, a nakon toga u svojoj knjizi Brani li Goldstein NDH (2002.) ${ }^{65}$, zbirci članaka prethodno objavljenih u hrvatskom tisku - mješavini inteligentnih točnih zapažanja i hrvatskih nacionalističkih stajališta, koja će ubrzo znatno uznapredovati matematičar Pečarić osvrnuo se na pisanja prof. dr. Ive i Slavka Goldsteina, koji su zastupali Žerjavićeve brojke sa svojim „korekcijama”, a posebno na njihovu knjigu Holokaust u Zagrebu, te se nemilo narugao Goldsteinovim brojkama - izračunima/procjenama, a za to ne treba biti matematičar. - U „umanjivanju” u Hrvatskoj novouspostavljenog broja jasenovačkih žrtava od 80.000 do 100.000, nakon prve faze 90-ih godina, koju možemo nazvati i „s Tuđmanom protiv Žerjavića \& Goldsteina”, slijedi druga, „umanjivačka” faza od potkraj 1990-ih/početka 2000-ih, koju možemo nazvati „i protiv Žerjavića \& Goldsteina i protiv Tuđmana”, koja uznapredovalo traje i danas.

U međuvremenu je Komisija za utvrđivanje ratnih i poratnih žrtava Republike Hrvatske, koja je od 1992. prikupljala podatke o ljudskim gubicima Hrvatske (i Hrvata) u Drugome svjetskom ratu i poraću, selektivnim pristupom popisala, prema izvještaju o svojem radu od veljače 1992. do rujna 1999., ukupno 261.415 osoba koje su život izgubile tijekom Drugoga svjetskog rata i u poraću. Komisija za utvrđivanje ratnih i poratnih žrtava Republike Hrvatske u popisivanju je pozornost posvetila ponajprije Hrvatima, i to uglavnom onima koje prethodni popisi ljudskih gubitaka u Drugome svjetskom ratu nisu iskazivali, a tek su usput popisivani i drugi. Pristranom podjelom ljudskih gubitaka na poželjne i nepoželjne popisala je tek 2238 žrtava logora Jasenovac i samo 293 židovske žrtve na području Hrvatske ukupno. ${ }^{66}$ Takav pristup objašnjavala je time da postoji nekoliko opsežnih popisa jasenovačkih žrtava, kao i popisi u Židovskoj općini u Zagrebu i Hrvatskome državnom arhivu u Zagrebu. ${ }^{67} \mathrm{No}$ uza sve ograde koje je Komisija za utvrđivanje ratnih i poratnih žrtava Republike Hrvatske iznosila, to nije točno jer je dotad jedini sustavni popis žrtava logora Jasenovac bio popis Komisije za popis žrtava rata SIV-a SFR Jugoslavije iz 1964., koji je objavljen 1992. odnosno 1998. godine ${ }^{68}$, a popisi žrtava u zagrebačkoj Židovskoj općini i Hrvatskome državnom arhivu nepotpuni su i

${ }^{64}$ PEČARIĆ, Srpski mit o Jasenovcu. Skrivanje istine o beogradskim konc-logorima i PEČARIĆ, Srpski mit o Jasenovcu II. O Bulajićevoj ideologiji genocida hrvatskih autora.

${ }_{65}$ PEČARIĆ, Brani li Goldstein NDH.

66 Usp. Izvješće o radu Komisije za utvrdivanje ratnih i poratnih žrtava, 15-16, 19-20.

67 Usp. GEIGER, „Brojidbeni pokazatelji o žrtvama logora Jasenovac, 1941.-1945., 219 i ondje navedena literatura.

68 Usp. Spisak žrtava rata 1941-1945. Ustaški logor Jasenovac i Jasenovac. Žrtve rata prema podacima Statističkog zavoda Jugoslavije. 
nesređeni. Znakovito je da su uzbunu u hrvatskoj i srpskoj javnosti potaknuli brojevi jasenovačkih i židovskih žrtava iako je u kroatocentričnom i selektivnom pristupu Komisije za utvrđivanje ratnih i poratnih žrtava Republike Hrvatske popisan i iskazan izuzev Hrvata i zanemariv broj gubitaka ostalih nacionalnih/etničkih skupina. ${ }^{69}$

Uslijedio je od početka 2000-ih nastup pojedinaca i skupina koji uporno zastupaju svoje osebujno manirističko viđenje NDH i logora Jasenovac te ustraju u tome da broj žrtava logora Jasenovac nije i - najjednostavnije rečeno - ne može biti veći od četveroznamenkastog (primjerice: mr. Mladen Ivezić, mr. Blanka Matković, Roman Leljak i dr. Stjepan Razum). Primjetno je da ti povjesničari i povjesničari-amateri imaju neizmjernu potporu u ekstremnim nacionalističkim medijima, ponajprije TV-emisiji Bujica i zadarskom Hrvatskom tjedniku, ali i u tisku Katoličke crkve, ponajprije Glasu Koncila. Usto, rimokatolički župni uredi po Hrvatskoj i zapadnoj Hercegovini postali su uobičajena mjesta predstavljanja njihovih pisanih uradaka. - Utočište takvih stajališta među povjesničarima u Hrvatskoj je ponajprije na Odsjeku za povijest Hrvatskih studija Sveučilišta u Zagrebu.

\begin{tabular}{|l|r|}
\hline \multicolumn{2}{|c|}{ Broj žrtava logora Jasenovac prema: } \\
\hline Mladen Ivezić & oko 1000 \\
\hline Blanka Matković & oko 7000 \\
\hline Roman Leljak i Stjepan Razum & 1654 i 1360 \\
\hline
\end{tabular}

Poseban je slučaj među hrvatskim povjesničarima istraživačima, i „umanjivačima”, žrtava logora Jasenovac mr. Mladen Ivezić, pisac knjiga Jasenovac. Brojke (2003.) i Titov Jasenovac (2014., samizdat). ${ }^{70}$ Zaključak svojega dugogodišnjeg bavljenja pitanjem ratnoga i poratnoga logora Jasenovac, preopterećenog ekstremnim hrvatskim nacionalizmom i neskrivenim antisemitizmom, Ivezić je najizravnije iznio u intervjuu Glasu Koncila u srpnju 2014. godine. Prema Iveziću, u logoru Jasenovac žrtava je „najvjerojatnije [je] oko 1000, umrlih od svih uzroka, najviše naravno smrću, pa od tifusa i slično" ${ }^{71}$ - No knjiga povjesničara Vladimira Mrkocija i isusovca dr. Vladimira Horvata Ogoljela laž logora Jasenovac (Zagreb, 2008.), ${ }^{72}$ - u kojoj opovrgavaju utemeljenost tvrdnji da je Jasenovac bio logor smrti i najčešće navođene brojke žrtava, i $700.000 \mathrm{u}$ Srbiji i 80.000 u Hrvatskoj, pri čemu upućuju na znatno manje pokazatelje te otvaraju i(li) proširuju neka pitanja, i o poslijeratnom logoru Jasenovac, ali ne

\footnotetext{
69 Usp. Izvješće o radu Komisije za utvrđivanje ratnih i poratnih žrtava, 16; GEIGER, „Brojidbeni pokazatelji o žrtvama logora Jasenovac, 1941.-1945.”, 220 i ondje navedena literatura.

70 Usp. IVEZIĆ, Jasenovac. Brojke i IVEZIĆ, Titov Jasenovac.

71 „Intervju. Mr. Mladen Ivezić, autor knjige 'Titov Jasenovac”, 6-7.

72 MRKOCI, HORVAT, Ogoljela laž logora Jasenovac.
} 
daju i uvijek utemeljene odgovore - označila je prekretnicu u pristupu pitanju jasenovačkoga logora i broju žrtava, i ustvari pretkazala osnivanje Društva za istraživanje trostrukog logora Jasenovac, čiji su idejni začetnici bili Mrkoci i isusovac Horvat, a stajališta koja su oni zacrtali najizravnije će biti iznesena i podrobnije razrađena u knjizi Vladimira Horvata, Igora Vukića, Stipe Pilića i Blanke Matković Jasenovački logori - istraživanja, objavljenoj 2015. u izdanju Društva za istraživanje trostrukog logora Jasenovac. ${ }^{73}$ - Uslijedio je žestok odgovor najprije u antifašističkom, točnije ljevičarskom tisku, ali i u uvjetno neutralnom tisku i na internetskim portalima, često i neodmjeren, kao što je najčešće bio neodmjeren i pokušaj revizije dotad prevladavajućih navoda i tvrdnji, ali i izravan i sustavan odgovor slijeva u publicistici i znanstvenoj literaturi. ${ }^{74}$

U hrvatskoj se javnosti 2010. pojavila vjerodostojna, ali ničim potvrđena i teško dokaziva točna brojka zatočenika logora Jasenovac. Ilija Barbarić, bivši ustaša nastanjen u Brazilu, tvrdi da je 1. svibnja 1945. imao u rukama „registarske knjige logora Jasenovca" te da su bile upisane sve osobe koje su prošle kroz logor od njegova osnutka do raspuštanja. Barbarić tvrdi da su knjige s popisima logoraša „spalili prije nego smo napustili Zagreb, 7. svibnja 1945.” Prema „knjigama registracije”, tvrdi Barbarić, kroz Jasenovac je prošlo ukupno 18.600 zatvorenika, uključujući i one koji su otpremljeni u Njemački Reich na prisilni rad. ${ }^{75}$ - To je pak u suprotnosti s uličnim i birtijskim mudrovanjima hrvatskih nacionalista, prema kojima su dokumenti iz Jasenovca i popisi logoraša u Beogradu i Srbi „skrivaju dokumente iz Jasenovca, ili su ih i uništili”.

Dr. Stjepan Razum, katolički svećenik i povjesničar, voditelj Nadbiskupijskoga arhiva u Zagrebu, član brojnih hrvatskih kulturnih društava i udruga, u nekima i obnašatelj važnih dužnosti, i prvi predsjednik 2015. osnovanog Društva za istraživanje trostrukog logora Jasenovac, već se niz godina na osebujan, samo njemu svojstven način zauzima za reviziju prevladavajućih i desetljećima promicanih navoda o razmjerima ljudskih gubitaka u vrijeme $\mathrm{NDH}$, a napose o žrtvama logora Jasenovac. Sve što se ne uklapa u njegova stajališta i znanja neopterećena činjenicama proziva i proglašava "protuhrvatskim uradcima”. ${ }^{76}$ Razum zastupa otprije u određenim hrvatskim krajnjim nacionalističkim krugovima jedino prihvatljiva, ali i teško dokaziva stajališta da je u poraću logor Jasenovac „imao duže trajanje, nego li onaj ratni. U poslijeratnom logoru [Jasenovac] stradao je neizmjerno veći broj nego li u ratnom logoru”. Dr. Razum

73 IVEZIĆ, Titov Jasenovac i HORVAT et al., Jasenovački logori - istraživanja.

74 Usp. primjerice: S. GOLDSTEIN, I. GOLDSTEIN, Jasenovac. Tragika, mitomanija, istina i KASAPOVIĆ, „Genocid u NDH: Umanjivanje, banaliziranje i poricanje zločina”, 7-33.

75 BARBARIĆ, Nezavisna Država Hrvatska bilo je pravo ime, 100.

76 Usp. GEIGER, „Dokon pop i jariće krsti’ ili jesu li postojali rasni zakoni u NDH?” i GEIGER, „Čemu služi Razum?”, 619-629. 
tvrdi da je Jasenovac za vrijeme NDH bio „radni i tranzitni logor. U njemu se nije provodilo ubijanje”, i zaključuje bez zadrške da „za masovna ubijanja u logoru Jasenovac nema nikakvih dokaza”, zatim i da su „najbrojniji logoraši bili sami Hrvati, protivnici ustaškoga režima”, kao i da je „točan broj žrtava logora Jasenovac niži od najniže službene komunističke procjene". ${ }^{77}$ Nije zanemariva mogućnost da je „točan broj žrtava logora Jasenovac niži od najniže službene komunističke procjene”, ali nije jasno na temelju kojih pokazatelja dr. Razum ustvrđuje da su „najbrojniji logoraši bili sami Hrvati, protivnici ustaškoga režima”. Usto vjerodostojnih potvrda da je u poraću u Jasenovcu stradao „neizmjerno veći broj nego li u ratnom logoru” jednostavno nema. No velečasni dr. Razum uporno i bez imalo zadrške ponavlja tvrdnje da je „Popis žrtava u Jasenovcu potpuno [je] lažan i izmišljen, u Jasenovcu nije NDH ubijala Srbe, nego su nakon rata partizani i komunisti ubijali hrvatske domoljube [...]" ${ }^{78}$ - Svoje sabrane umotvorine o NDH i logoru Jasenovac objavio je dr. Razum 2018. u knjizi Razotkrivena jasenovačka laž, u suautorstvu s akademikom Josipom Pečarićem, ${ }^{79}$ koji je u međuvremenu postao „moralna vertikala” u Hrvata. Dr. Razum je u ožujku 2018. hrvatskom narodu obznanio „konačnu istinu” o broju jasenovačkih logoraša i broju logoraša koji su u logoru Jasenovac izgubili život. Naime, on tvrdi da je sveukupno u vrijeme NDH, od 1941. do 1945., bilo tek 18.600 jasenovačkih logoraša, a da je od toga njih $1360 \mathrm{u}$ logoru Jasenovac i „smrtno stradalo”. - „Prirodnom smrću, od teških oboljenja ili od posljedica najtežih kazni logorske uprave!"80 - Kako je dr. Razum došao do „konačne istine” o broju jasenovačkih logoraša i broju logoraša koji su u Jasenovcu izgubili život? - Bez razmišljanja je povjerovao izmišljotinama Romana Leljaka, o čemu ukratko poslije.

Igor Vukić jedini se od istaknutih jasenovačkih „revizionista” u svojim javnim istupima, napisima i knjigama ${ }^{81}$ - čije pisane uratke o logoru Jasenovac neki znanstvenici slijeva nazivaju „toksičnim šundom”"2 a domoljubi zdesna nepodijeljeno hvale kao „Znanstvene” i „istinoljubive” ${ }^{83}$, svjestan očito

\footnotetext{
77 Usp. „Intervju. Dr. Stjepan Razum, povjesničar i arhivist: Vrijeme je da srušimo velikosrpski mit o Jasenovcu”, 28-35. Usp. primjerice i: „Intervju. Dr. Stjepan Razum. U Jasenovcu partizani su svoje okrutne i masovne zločine podmetnuli ustašama - mi povjesničari to ćemo i dokazati!", 3033 i RAZUM, „Jasenovac, najveća povijesna laž koja iz dana u dan postaje sve prozirnija”, 18-25.

78 Usp. RAZUM, „Logor Jasenovac kao sredstvo trajne komunističke indoktrinacije”, 18-20.

79 Usp. PEČARIĆ, RAZUM, Razotkrivena jasenovačka laž.

80 Usp. FRKOVIĆ, „Knjiga akademika Pečarića i dr. Razuma donosi konačnu istinu o 18600 logoraša u Jasenovcu i 1360 smrtno stradalih".

${ }_{81}$ Usp. VUKIĆ, „Sabirni i radni logor Jasenovac, 1941.-1945.”, 55-144; VUKIĆ, Radni logor Jasenovac i VUKIĆ, Jasenovac iz dana u dan. Kronologija.

82 KASAPOVIĆ, „Vukićeva knjiga o Jasenovcu toksični je šund”, 34-37.

83 Usp. primjerice: PEČARIĆ, RAZUM, Razotkrivena jasenovačka laž, 328-424 [III. Hajka na Igora Vukića].
} 
koliko je to „sklizak teren” - nije upuštao u procjene ili spominjanje broja žrtava logora Jasenovac. No pozivajući se selektivno na logorske dokumente i iskaze/sjećanja jasenovačkih zatočenika, Vukić spominje tek različite brojke o logorašima u Jasenovcu 1941. i početkom 1942., koje su u najčešće rasponu od 1100 do 1200 do potkraj 1941. i 1500 početkom 1942. godine. Osporava poimenični popis JUSP-a Jasenovac te ustvrđuje da „popis s više od 83.000 imena navodnih žrtava uglavnom nema stvarne veze s Jasenovcem". Prema Vukiću, u Hrvatskoj je taj jasenovački popis „službeno prihvaćen” unatoč tome „što, primjerice, dokumenti i veći broj bivših logoraša govori da je u Jasenovcu 1941. bilo oko 1.200 zatočenika, popis kaže da ih je tada ubijeno 10.700 " ${ }^{84}$ Tvrdi da je u logoru Jasenovac III Ciglana „bilo mjesta za oko 2.000 zatočenika i toliko ih je, manje-više stalno boravilo u Jasenovcu gotovo cijelo vrijeme postojanja logora". Prema Vukiću, Jasenovac je bio radni logor i nema dokaza o masovnim ubojstvima, te ustvrđuje da nitko nije u Jasenovac doveden, niti ondje ubijen, samo zato što je pravoslavac ili Srbin ${ }^{85}$ - Usput, moramo se složiti s motom Vukićeve knjige Radni logor Jasenovac: „Na savjest svima koji su lagali o Jasenovcu." No primjetno je da Vukić, sadašnji predsjednik Društva za istraživanje trostrukog logora Jasenovac - i tko kaže da Srbin ne može biti na vodećem položaju u Hrvatskoj - na zajedničkim javnim istupima s još istaknutijim jasenovačkim sveznalcima, primjerice s dr. Stjepanom Razumom i Romanom Leljakom, nije imao prigovora na njihove izopačene priče o NDH i logoru Jasenovac, a ni na njihove izmišljotine o ukupnom broju zatočenika i ukupnom broju jasenovačkih žrtava. - Da, mudro, jer „tjeramo vodu na isti mlin".

Svoja maniristička stajališta o NDH i logoru Jasenovac mr. Blanka Matković iznijela je u niz navrata, a najopširnije i najizravnije u intervjuu za Hrvatski tjednik u siječnju 2017., kada je ustvrdila: „Svoju povijest pisat ćemo mi. Nemamo se čega sramiti, ni NDH, ni Jasenovca, odbacimo povijest koju je pisala Partija nakon 1945.” Usto je zaključila da je „Jasenovac [je] najveći falsifikat hrvatske povijesti”, brojka od 80.000 „navodno” ubijenih „Žerjavićeva laž”, a JUSP Jasenovac „širi četničku propagandu”. ${ }^{86}$ - Na mrežnim stranicama Hrvatske družbe povjesničara „Dr. Rudolf Horvat”, osnovane 2008., objavila je predsjednica i osnivačica te družbe povjesničarka Matković početkom ožujka 2017. članak „Jasenovac. Dosje Ante Pavelića: Popis osoba stradalih u logoru Jasenovac", a zatim u Hrvatskom tjedniku u travnju 2018. članak [potpisano: Zmajo] „Kako je nastao i razvijao se velikosrpski jasenovački mit i zašto je

${ }_{84}$ Usp. VUKIĆ, Radni logor Jasenovac, 17-18, 59-60, 299.

85 VUKIĆ, Jasenovac iz dana u dan. Kronologija, 9.

86 Usp. „Ekskluzivni intervju. Mr. sc. Blanka Matković, predsjednica Hrvatske družbe povjesničara Dr. Rudolf Horvat”, 37-49 i „Intervju. Fascinantni intervju koji će srušiti lažnu komunističku povijest. Mr. sc. Blanka Matković”, 29-44. 
ostao službeni, državni kult, čak i u današnjoj Hrvatskoj?", u kojem napominje da se u tom dosjeu u Hrvatskome državnom arhivu u Zagrebu „nalaze [se] i popisi djece, žena i staraca navodno ubijenih u logorima Jasenovac i Stara Gradiška”, u kojima se spominje nešto manje od 10.000 osoba. Usto je, naglašava, „ove popise tek potrebno analizirati i usporediti s ostalim podacima te da ni u kom slučaju ne možemo tvrditi da su oni točni”. Povjesničarka Matković dalje ustvrđuje da broj od oko 7000 jasenovačkih žrtava (bez Stare Gradiške) koji se spominje u dosjeu Pavelić odgovara broju koji je „izrekao” general Jugoslavenske narodne armije Kosta Nađ u Vjesniku 6. svibnja 1981. u tekstu naslovljenom „Borci jedinstveni u obrani tekovina revolucije”: „Kao da već odavno nije poznato i znanstveno utvrđeno da je u tom zloglasnom logoru likvidirano oko sedam tisuća, a ne 'deseci tisuća' nevinih ljudi, djece, staraca i žena." ${ }^{\text {87 }}$ Ali povjesničarka Matković zaboravila je spomenuti da je u Vjesniku idućega dana objavljen ispravak napisa „Borci jedinstveni u obrani tekovina revolucije” i upozoreno da se „potkrala [se] štamparska greška” te da u ispravku piše: „, $[. .$. Međutim rečenica pravilno glasi: Kao da već odavno nije poznato i znanstveno utvrđeno da je u tom zloglasnom logoru likvidirano oko sedam stotina tisuća, a ne 'deseci tisuća' nevinih ljudi, djece, staraca i žena." ${ }^{88}$ - Da, trebalo je naivnosti i povjerovati ili barem neizmjerno priželjkivati da general Jugoslavenske narodne armije Nađ nije izrekao brojku od 700.000 žrtava logora Jasenovac.

U Hrvatskoj, kao i u Srbiji, svatko misli da je pozvan meritorno raspravljati o NDH i logoru Jasenovac. - Josip Kljaković-Šantić objavio je 2016. u Zagrebu knjigu Jasenovac - enigma holokausta, u kojoj se „udubio” u analizu poimeničnoga popisa Jasenovac Research Institute (Brooklyn, New York, SAD), o kojem će još biti riječi. Da se radi o popisu iz 1964. godine na stranicama Jasenovac Research Institute upozorio sam u Časopisu za suvremenu povijest 2011. i 2013. godine. ${ }^{89}$ Ali autor, umirovljeni kapetan fregate Jugoslavenske ratne mornarice, pomorac, novinar, pisac, pjesnik i što sve ne, koji se upustio i u nezaobilazna pitanja hrvatske historiografije, nije shvatio što je popis na mrežnim stranicama toga instituta. Najvažnije je da na popisu u knjizi korištene literature na prvome mjestu navodi Bibliju. No, što je poimenični popis koji donosi Jasenovac Research Institute nisu shvatili ni recenzenti (sic!) njegove knjige, novinari i publicisti Tomislav Vuković, Igor Vukić i Ante Be-

\footnotetext{
87 Usp. [ZMAJO], „Jasenovac. Dosje Ante Pavelića: Popis osoba stradalih u logoru Jasenovac” i MATKOVIĆ, „Kako je nastao i razvijao se velikosrpski jasenovački mit i zašto je ostao službeni, državni kult, čak i u današnjoj Hrvatskoj?", 31.

88 „Ispravak”, 3.

89 Usp. GEIGER, „Ljudski gubici Hrvatske u Drugom svjetskom ratu koje su prouzročili okupatori i njihovi pomagači'. Brojidbeni pokazatelji”, 724 i GEIGER, „Brojidbeni pokazatelji o žrtvama logora Jasenovac, 1941.-1945.", 223.
} 
ljo. Uostalom, to nije shvatila ni povjesničarka Matković, uzdanica hrvatskih nacionalista boraca za „istinu” o jasenovačkom logoru..$^{90}$

Među mnogobrojnim senzacionalnim „otkrićima” koja Roman Leljak već niz godina u javnim istupima i uspješnom „prodavanju magle” od ponajprije Hrvatskoga tjednika do Glasa Koncila podastire Hrvatima posebno i istaknuto mjesto imaju njegovi precizno izmišljeni brojevi jasenovačkih logoraša i žrtava logora Jasenovac. Kruna njegova istraživanja o ukupnom broju jasenovačkih logoraša i broju žrtava logora Jasenovac njegova je knjiga i film Mit o Jasenovcu, objavljeni potkraj 2018. godine. ${ }^{91}$ - Leljak je početkom 2018. Hrvatima najavio da će „uskoro objaviti dokumente [...] iz arhiva u Beogradu koji dokazuju stvarni broj žrtava Jasenovca” i da je riječ o ukupno 1654 osobe. Poslije je pak tvrdio: „Više je nego jasno da je u samom logoru Jasenovac 3C na različite načine (prirodne smrti, bolesti ili likvidacije i presude zbog kršenja propisa koji su tada važili i koji su doneseni u samo[m] logoru Jasenovac) ukupno umrlo 1360 žrtava, a što je sukladno sondiranjima koja su rađena 1964.” i izmislio da su voditelji toga antropološkog istraživanja „dali procjenu da je u samom logoru Jasenovac bilo oko 1300 žrtava, što je sukladno popisu koji sam pronašao, [...]”. Usto je tvrdio: „U logoru Jasenovac od 1941. do 1945. ukupno je bilo 18600 zarobljenika." ${ }^{2}$ - No Leljak u svojoj knjizi Mit o Jasenovcu donosi tek dva dokumenta - popisa, jedan Zemaljske komisije za utvrđivanje zločina okupatora i njihovih pomagača Federalne Države Hrvatske, u kojem je navedeno 576 osoba, i dokument čiji je tvorac nepoznat, a u kojem je navedeno 1078 osoba, i to samo žena (što zbrojeno iznosi 1654) i koje proglašava „Popisom žrtava logora Jasenovac”. - Imalo upućenima jasno je da se ne radi o nekim posebnim dokumentima iz Beograda koji bi donosili ukupan broj jasenovačkih žrtava, kako je to Leljak senzacionalistički mjesecima najavljivao Hrvatima željnima „istine”. - U svojoj knjizi spominje i antropološka istraživanja 1964. godine. Zapisnik iskopavanja - sondiranja 1964. na području Jasenovca III odavno je poznat i objavljen, i dostupan u Hrvatskome državnom arhivu, u fondu 1241 - SUBNOR Hrvatske, no sada ga Leljak neupućenima „prodaje” kao svoje otkriće i postaje mu ključni dokaz za to koliko je u logoru Jasenovac ukupno žrtava: „U zapisniku ne navode analizu i pretpostavku ukupnog broja žrtava na području groblja u logoru. No, danas možemo na osnovu poznate veličine groblja, te broja sonda koje su iskopali, procijeniti da je na groblju oko 1300 žrtava." - Nije li Leljak prije tvrdio suprotno - da su voditelji toga

90 Usp. MATKOVIĆ, „Kako je nastao i razvijao se velikosrpski jasenovački mit i zašto je ostao službeni, državni kult, čak i u današnjoj Hrvatskoj?", 31.

91 LELJAK, Mit o Jasenovcu. Dokumentarni film - dokumenti.

92 Usp. GEIGER, „U povodu 10. travnja ili kako je Roman Leljak došao do 'otkrića’ o ukupnom broju jasenovačkih logoraša - 18.600 i ukupnom broju žrtava logora Jasenovac - 1654?" i ondje navedena literatura. 
antropološkog istraživanja „dali procjenu da je u samom logoru Jasenovac bilo oko 1300 žrtava”? Leljak ustvrđuje da se broj od 1300 žrtava „podudara sa očuvanim dokumentom o umrlima u radnom logoru Jasenovac koji je pronađen u Vojnom arhivu u Beogradu". - Koji je to dokument iz Vojnoga arhiva? Jer dokumenti koje je objavio i proglasio ukupnim brojem jasenovačkih žrtava iz Arhiva su Jugoslavije u Beogradu, a njihovi su izvornici u Hrvatskome državnom arhivu u Zagrebu. - Vojni arhiv u Beogradu da zvuči tajnovitije i uvjerljivije. - U knjizi Mit o Jasenovcu istovremeno tvrdi i da je prema popisu jasenovačkih žrtava ukupno 1654, a i da „danas možemo na osnovu poznate veličine groblja, te broja sonda koje su iskopali, procijeniti da je na groblju oko 1300 žrtava”. Leljak malo ovako, malo onako. Koga briga, jer mnogobrojni krajnje neupućeni i lakovjerni Hrvati prihvaćaju svaku njegovu izmišljotinu. - Leljak tvrdi: „Broj od 18600 potvrđuju imena i prezimena svih koji su primali pakete.” Baš me zanima koji je to dokument ili popis, i gdje se nalazi, koji potvrđuje da je 18.600 osoba primalo pakete? Leljak je i to kao i ostale svoje ključne dokaze izmislio. - Kako je Leljak došao do „konačne istine” o broju jasenovačkih logoraša? Ponavljao je neprovjerljivu tvrdnju ustaše Barbarića da je kroz logor Jasenovac prošlo ukupno 18.600 osoba. A zašto i ne bi, mnogima se ta brojka učinila spasonosnom. ${ }^{93}$ - Leljak je osoba koja na sva ključna pitanja Jasenovca, a i Bleiburga, ima rješiteljni odgovor. I samo krajnje neupućenima nije jasno da Leljak svoja „otkrića”, tvrdnje i zaključke u javnim istupima i konačno u knjizi i filmu Mit o Jasenovcu temelji na izmišljenim činjenicama. - Postavlja se pitanje ozbiljnosti i(li) najblaže rečeno naivnosti, ali i moralne odgovornosti pojedinaca, udruga i medija koji svesrdno i bez zadrške podržavaju i promiču Leljakova „otkrića”, i o karakteru logora Jasenovac i o broju jasenovačkih žrtava. - Uza sve „istinoljubivi” Hrvati i dalje su mu neizmjerno zahvalni i u iščekivanju su njegovih novih spasonosnih „otkrića” o logoru Jasenovac i još koječemu.

Mudrovanja o logoru Jasenovac iznosili su i istaknuti hrvatski političari. - Početkom 2017. u javnost je „iscurila” videosnimka Stjepana Mesića, posljednjega predsjednika Predsjedništva SFR Jugoslavije 1991. i predsjednika Republike Hrvatske u dva mandata (2000. - 2010.) te počasnoga predsjednika Saveza antifašističkih boraca i antifašista Republike Hrvatske, kako u „veselom društvu” u veljači 1992. objašnjava o logoru Jasenovac, ustvrđujući da je Josip Broz Tito „znao da je to falsifikat jer je trebalo prikazat> što veće žrtve da se dobiju [reparacije]” i da zato „nikad nije posjetio Jasenovac”. Mesić tvrdi da su to bili „radni pogoni” i da „ubojstva jednostavno nisu istinita. [...]”.

93 Usp. LELJAK, Mit o Jasenovcu. Dokumentarni film - dokumenti, 26-29, 258-284, 297-298 i GEIGER, „U povodu 10. travnja ili kako je Roman Leljak došao do 'otkrića' o ukupnom broju jasenovačkih logoraša - 18.600 i ukupnom broju žrtava logora Jasenovac - 1654?”. 
Umiranja u logoru objašnjava zaraznim bolestima. Prema Mesiću, logori su bili uobičajeni u to vrijeme u Europi, i u njima su bili „izolirani” oni „koji su mogli aktualnom režimu smetati”. Usto tvrdi: „Puno je 25 tisuća, ali nisu to samo Srbi. [...]” A u masovnim grobnicama i hrvatski su vojnici ubijeni u poraću, i u Jasenovcu je logor „radio poslije rata još dvije godine” ${ }^{94}$ A kako je Mesić „antifašist”, to nije revizionizam. - No „istinu” o logoru Jasenovac raznim neutemeljenim tvrdnjama, uz mnoštvo netočnih navoda, a i nedvojbenih krivotvorina ${ }^{95}$, znalački je 2016. kompromitirao hrvatski redatelj Jakov Sedlar svojim dokumentarnim filmom Jasenovac - istina, u kojem se tvrdi da je u Jasenovcu ubijeno više zatočenika kada su ga koristili komunisti nego kada su ga koristili ustaše, te je naveliko hvaljen u nacionalističkom tisku kao „dosad najtočnije i povijesno najautentičnije djelo na tu temu"96, pa je i razumljivo da je u travnju 2017. dobio Nagradu Grada Zagreba. ${ }^{97}$

Tijekom 90-ih i početkom 2000-ih u hrvatskim udžbenicima povijesti uz redoviti navod da su ustaše provodili teror protiv Židova, Roma, Srba te Hrvata komunista i antifašista, i da je najveći koncentracijski logor „i po zlu glasu najpoznatiji bio onaj u Jasenovcu”, prevladava nespominjanje broja jasenovačkih žrtava ${ }^{98}$ ili pak tek neodređeno spominjanje toga broja: „više desetaka tisuća ljudi, najviše Srba i Židova” / „život izgubilo više desetaka tisuća ljudi raznih nacionalnosti” / „stradali deseci i deseci tisuća ljudi”. ${ }^{9}$ Žerjavićevi izračuni/procjene broja jasenovačkih žrtava i brojidbeni pokazatelji poimeničnoga popisa JUSP-a Jasenovac u hrvatske su udžbenike povijesti uvršteni nešto kasnije.

Uza sva potrebna i često opravdana upozorenja o netočnim upisima, provjere i pročišćavanja poimeničnoga popisa JUSP-a Jasenovac dr. Nikole Banića (Fakultet elektrotehnike i računarstva, Zagreb) i dr. Mladena Koića, objavljivana posljednjih godina u Hrvatskom tjedniku, nisu - iako je riječ o većim brojkama, kako tvrde - rezultirala znatnijim promjenama ukupnoga broja jasenovačkih žrtava. - Banić i Koić od ukupno 83.813 žrtava na mrežnom popisu JUSP-a Jasenovac 55.915 proglašavaju „lažnim i nepouzdanim”. ${ }^{100}$ No 42.307 „žrtava uz čije ime stoji da je nepouzdan jedan od osnovnih podata-

\footnotetext{
94 Usp. „Stipe Mesić osporava 'istinu' o Jasenovcu!”.

95 Usp. „Otkrivamo - Jasenovac - fotošopirana istina: Sedlarov udarni argument o plivanju leševa uzvodno je loša montaža”.

96 Usp. „Intervju. Redatelj Jakov Sedlar nedavno je završio dokumentarni film 'Jasenovac - istina' na kojemu je radio punih 12 godina”, 44-47.

97 Hina, „Većinom glasova. Skupština odlučila - Sedlaru Nagrada grada Zagreba”.

98 Usp. primjerice: PERIĆ, Povijest za VIII. razred osnovne škole, 89.

99 Usp. primjerice: MIROŠEVIĆ et al., Povijest. Udžbenik za II. razred strukovnih škola, 221; KOREN, Povijest 8. Udžbenik za 8. razred osnovne škole (2003.), 141 i Ves. ĐURIĆ, Povijest 8. Udžbenik za osmi razred osnovne škole, 90.

100 Usp. BANIĆ, KOIĆ, „Jasenovački mit u 'dobrom’ društvu Kominterne”, 17-19.
} 
ka”, kao i 17.182 „žrtava s imenom i prezimenom, ali bez imena oca, mjesta ili godine” ne potvrđuje nedvojbeno da su te žrtve „lažne i nepouzdane”. Ako su njihove provjere mrežnoga popisa JUSP-a Jasenovac točne, treba zabrinjavati ponajprije 3398 žrtava „za koje je dosad poimenično pokazano kako nisu stradale u Jasenovcu”, 1873 „dvostrukih, trostrukih i višestrukih klonova” i 1611 „žrtava kod kojih nije navedeno ni ime ni prezime”, njih ukupno 6882 (8,2 \%). Pribrojimo li im i 3671 „žrtava u kategoriji nestalih i kategoriji nepoznato”, pa i 2919 „Žrtava kod kojih nije navedeno ime ili prezime”, ukupno je 13.472 (16 \%) „lažnih i nepouzdanih” žrtava, što nije zanemarivo.

Značajke poimeničnoga popisa JUSP-a Jasenovac prema istraživanjima Nikole Banića i Mladena Koića, travanj 2020.

\begin{tabular}{|l|r|}
\hline Trenutačni broj žrtava na mrežnom jasenovačkom popisu & 83.813 \\
\hline Broj žrtava za koje nije navedeno ni ime ni prezime & 1611 \\
\hline Broj žrtava za koje nije navedeno ime ili prezime & 2919 \\
\hline $\begin{array}{l}\text { Broj žrtava s imenom i prezimenom, ali bez imena oca, mjesta ili } \\
\text { godine }\end{array}$ & 17.182 \\
\hline $\begin{array}{l}\text { Broj žrtava za koje je dosad poimenično pokazano da nisu stradale } \\
\text { u Jasenovcu }\end{array}$ & 3398 \\
\hline Broj dvostrukih, trostrukih i višestrukih klonova & 1873 \\
\hline $\begin{array}{l}\text { Broj žrtava uz čije ime stoji da je nepouzdan jedan od osnovnih } \\
\text { podataka }\end{array}$ & 42.307 \\
\hline Broj žrtava u kategoriji nestali i kategoriji nepoznato & 3671 \\
\hline Zbroj lažnih i nepouzdanih žrtava & 55.915 \\
\hline
\end{tabular}

Na hrvatskim internetskim portalima i u hrvatskom nacionalističkom tisku te publicistici i dijelom u historiografiji „revizionistička” stajališta o logoru Jasenovac posljednjih su godina učestala. Najsustavnije poricanje i(li) znatno umanjivanje ustaških zločina počinjenih u logoru Jasenovac zastupljeno je ponajprije $\mathrm{u}$ javnim istupima i pisanjima povjesničara i povjesničara-amatera Mladena Ivezića, Vladimira Mrkocija, Vladimira Horvata, Stipe Pilića, Blanke Matković, Igora Vukića, Josipa Pečarića, Stjepana Razuma i Romana Leljaka. No i hrvatska historiografija i publicistika slijeva uporna je u svojim starim i općepoznatim tvrdnjama, u čemu su zdušno potpomognuti mnogobrojnim svjetonazorski istovjetnim medijima, uključujući i najutjecajnije državne. A kako se i moglo očekivati u Hrvatskoj, svaka je strana - i zastupnici i promicatelji „novouspostavljene” brojke od 80.000 do 100.000 i novopridošli „revizionisti” i „umanjivači”, različitih sposobnosti i znanja - pozivajući se na istinoljubivost i znanstveni pristup, nepokolebljivo ostala pri svojim stajalištima i tvrdnjama o logoru Jasenovac, utemeljenim na prepoznatljivom selektivnom 
pristupu, a često i na izmišljenim, „hipotetičkim činjenicama”. - Dijaloga o pitanju logora Jasenovac u Hrvatskoj nema ili, točnije, dijalog je prepun najblaže rečeno izljeva prezira, pa i neskrivene mržnje, suprotstavljanja onome tko misli i zastupa drukčije, nazivajući jedni druge pamfletistima i krivotvoriteljima.

Promicanje brojke od 700.000 žrtava logora Jasenovac nakon raspada SFR Jugoslavije u Republici Srbiji - od Milana Bulajića do Gideona Greifa

Sustavna javna preispitivanja ljudskih gubitaka Jugoslavije u Drugome svjetskom ratu javljaju se 80-ih godina, kada su jugoslavenska vlast i komunistička ideologija počele nezaustavljivo gubiti uvjerljivost. Ali u licitiranju žrtvama logora Jasenovac srpska se strana zabarikadirala jugoslavenskom komunističkom izmišljotinom i enciklopedijski obznanjenom (Vojna enciklopedija i Enciklopedija Jugoslavije) brojkom od 700.000 žrtava logora Jasenovac. Štoviše, brojka žrtava Jasenovca navođena tada u jugoslavenskoj historiografiji i publicistici iskazivala je napose kod srbijanskih autora i tendenciju rasta. Unatoč evidentnim pokazateljima svih popisa ljudskih gubitaka Jugoslavije u Drugome svjetskom ratu, dugotrajnom i upornom kampanjom dokazivanja o stotinama tisuća ubijenih u logorima NDH broj žrtava logora Jasenovac postupno je eskalirao i nakon Memoranduma Srpske akademije nauka i umetnosti 1986. godine dosegnuo više od milijun ubijenih Srba samo u Jasenovcu. ${ }^{101}$ Tijekom i učestalo potkraj 80 -ih i u godinama koje su slijedile u srpskim nacionalističkim krugovima označena je skupina istaknutih pojedinaca u Hrvatskoj, ponajprije dr. Franjo Tuđman, prof. dr. Ljubo Boban, Vladimir Žerjavić i Slavko Goldstein, koje se proglašavalo nositeljima „minimiziranja” srpskih stradanja u NDH i žrtava logora Jasenovac. ${ }^{102}$ - Naglašena i učestala zloupotreba nestvarnih razmjera ustaških zločina nad Srbima u NDH i broja jasenovačkih žrtava uoči i tijekom raspada SFR Jugoslavije, u kojoj su određeni znanstveni, ponajprije povjesničarski krugovi poslužili kao transmisija, bila je u Srbiji prvorazredno i učinkovito sredstvo ubrzane homogenizacije srpstva i ratne promidžbe 90 -ih godina.

Na Međunarodnom znanstvenom skupu Genocid nad Srbima u II svetskom ratu Odbora Srpske akademije nauka i umetnosti za sakupljanje građe o genocidu protiv srpskog naroda i drugih naroda Jugoslavije u XX veku, odr-

101 Usp. primjerice: BULATOVIĆ, Koncentracioni logor Jasenovac, s posebnim osvrtom na Donju Gradinu.

102 Usp. MIRKOVIĆ, Objavljeni izvori i literatura o jasenovačkim logorima; NIKOLIĆ, „Polemike o genocidu u NDH u jugoslovenskoj istoriografiji 1985-1989.", 425-452; ĆULIBRK, Istoriografija holokausta u Jugoslaviji, 83-133; JURIĆ, „Jasenovačke žrtve i uspostava nacionalnog programa u Srbiji (1986. - 1995.)", 227-260 i KRUŠELJ, Zarobljenici paralelnih povijesti. I ondje navedena literatura. 
Žanom u Beogradu u listopadu 1991. - u vrijeme kada je Jugoslavenska narodna armija za račun Srbije pokušavala slomiti slabo naoružanu i organiziranu obranu Hrvatske - na kojem su se okupili najvažniji srbijanski povjesničari i istraživači suvremene povijesti, potvrđena su srpska nacionalistička stajališta o protusrpskoj usmjerenosti Katoličke crkve, genocidnosti Hrvata i stotinama tisuća, a najčešće 700.000 žrtava logora Jasenovac, uglavnom Srba. ${ }^{103}$ Takva stajališta zastupana su i u izlaganjima (najslikovitije: dr. Đorđe Lekić, „Jasenovac - najveći srpski grad pod zemljom”) i na Okruglom stolu Jasenovac, sistem ustaških logora smrti, održanom u Beogradu u travnju 1996. u suorganizaciji Muzeja žrtava genocida i Instituta za savremenu istoriju. ${ }^{104}$

I u najvažnijim izdanjima Instituta za savremenu istoriju u Beogradu 90ih godina koja su se bavila NDH beziznimno su navođena takva stajališta i megalomanske brojke žrtava logora Jasenovac. Tako primjerice Gojo Riste Dakina ili Gojko Škoro, ili tko se već krije iza toga imena, u svojoj knjizi Genocid nad Srbima u Nezavisnoj Državi Hrvatskoj: Budi katolik ili umri (1995.) zaključuje da je u logoru Jasenovac „ubijeno oko 700.-800.000 lica, uglavnom Srba, zatim rodoljubivih Hrvata, Jevreja i Roma”. ${ }^{105}$ Dr. Nikola Živković i dr. Petar Kačavenda u svojoj knjizi Srbi u Nezavisnoj Državi Hrvatskoj (1998.) ustvrđuju: „U materijalima koji su prikupljeni neposredno posle rata pominje se cifra od 600.000 lica. [...] samo na jednom delu stratišta Gradina sondama je utvrđeno 380.000 leševa. Koliko je na drugim mestima i delovima ovoga stratišta ubijeno, teško je reći, ali je sigurno da je cifra od 600.000, do koje je došla Zemaljska komisija za ratne zločine, blizu tačnom broju."106 - U srbijanskoj historiografiji 90-ih godina, a znatnim dijelom i sve do danas, primjetno je suglasje povjesničara u zaključivanju i neodustajanju od tvrdnje da je riječ o stotinama tisuća, najčešće 700.000, ali i više, žrtava logora Jasenovac.

Posebnu ulogu u očuvanju, nadogradnji i širenju ,jasenovačkoga mita” imao je 1992. osnovan Muzej žrtava genocida (MŽG) pod ravnateljstvom dr. Milana Bulajića, otprije, uz dr. Vladimira Dedijera ${ }^{107}$, jednoga od najupornijih zagovornika teze o protusrpstvu Katoličke crkve, genocidnosti Hrvata i stotinama tisuća žrtava logora Jasenovac, uglavnom Srba. ${ }^{108}$ A kakva bi zadaća MŽG-a trebala biti, i kakve bi brojke o jasenovačkim žrtvama trebalo utvrditi

\footnotetext{
103 Usp. Genocid nad Srbima u II svetskom ratu.

104 Usp. Jasenovac, sistem ustaških logora smrti. Saopštenja sa Okruglog stola održanog u Beogradu 23.4.1996.

105 DAKINA, Genocid nad Srbima u Nezavisnoj Državi Hrvatskoj: Budi katolik ili umri, 165. Institut za savremenu istoriju objavio je 2000. godine ovu knjigu pod imenom autora Gojko Škoro i na engleskom jeziku: Genocide over the Serbs in the Independent State of Croatia: Be Catholic or Die.

106 ŽIVKOVIĆ, KAČAVENDA, Srbi u Nezavisnoj Državi Hrvatskoj. Izabrana dokumenta, 28.

107 Usp. DEDIJER, Vatikan i Jasenovac. Dokumenti.

108 Usp. primjerice: BULAJIĆ, Ustaški zločini genocida i suđenje Andriji Artukoviću 1986. godine.
} 
i promicati, moglo se naslutiti i u najavama osnivanja Muzeja početkom 1990. godine. ${ }^{109}$ To će potvrditi i izdanja MŽG-a tijekom desetljeća kada je Muzej vodio Bulajić. ${ }^{110}$ Usto je Bulajić objavio niz knjiga na srpskom i engleskom jeziku u kojima se najjasnije iščitava njegovo viđenje hrvatskoga genocida nad Srbima u NDH i razmjeri zločina u logoru Jasenovac. ${ }^{111}$

Uza sva nastojanja, revizija - dopuna poimeničnoga popisa žrtava logora Jasenovac i Stara Gradiška iz 1964., koji donosi podatke za ukupno 59.188 žrtava, od čega je najviše Srba: $33.944^{112}$, napravljena u MŽG-u, a s dopunama donosi podatke za 78.163 osobe koje su život izgubile u logorima Jasenovac i Stara Gradiška, od čega je popisano najviše žrtava Srba: $47.123^{113}$ - nije potvrđivala megalomanske brojčane navode direktora Muzeja Bulajića i njegovih mnogobrojnih istomišljenika, ponajprije u Srbiji.

Znatan udjel u širenju srpske nacionalističke „istine” o razmjerima zločina počinjenih u logoru Jasenovac imalo je pet međunarodnih konferencija o logoru Jasenovac, održanih od 1997. do 2011., čiji je pokretač MŽG, odnosno Milan Bulajić, koje su mahom okupile uvjerene pristaše megalomanskih navoda o broju jasenovačkih žrtava. Tek poneki sudionici tih konferencija nisu zastupali stajališta o stotinama tisuća i(li) mitskih 700.000 žrtava logora Jasenovac, ponajprije oni iz Hrvatske: Vladimir Žerjavić na Prvoj konferenciji u New Yorku 1997., dr. Josip Jurčević (Hrvatski studiji Sveučilišta u Zagrebu) na Drugoj konferenciji u Banjoj Luci 2000., Slavko Goldstein na Trećoj konferenciji u Jeruzalemu 2002., ali i neki „usamljeni” sudionici iz Srbije poput Dragana Cvetkovića (MŽG) na Drugoj i Četvrtoj konferenciji u Banjoj Luci 2000. i 2007. godine. Među sudionicima iz Hrvatske bilo je i osoba poput Alena Budaja (Margelov institut, Zagreb), koji je na Četvrtoj konferenciji u Banjoj Luci 2007. ustvrdio da popis žrtava logora Jasenovac i Žerjavićev izračun/pro-

\footnotetext{
109 U posebnom izdanju lista Politika Svet (Beograd), exclusive broj 1, april 1990,, naslovljenom: „Istina o genocidu nad Srbima, Jevrejima, Ciganima i drugima”, objavljena su i neznatno skraćena izlaganja - rasprave s okrugloga stola održanog početkom veljače 1990., na kojemu je potaknuto osnivanje Muzeja žrtava genocida u Beogradu („Okrugli sto - Muzej žrtava genocida”).

110 Usp. MIRKOVIĆ, Objavljeni izvori i literatura o jasenovačkim logorima i MIRKOVIĆ, „Izdanja Muzeja žrtava genocida i građa o ljudskim gubicima u tim izdanjima”, 573-591.

111 Usp. primjerice: BULAJIĆ, Misija Vatikana u Nezavisnoj Državi Hrvatskoj; BULAJIĆ, Tudjman's „Jasenovac Myth”. Ustasha crimes of Genocide; BULAJIĆ, „Jasenovački mit” Franje TudmanaGenocid nad Srbima, Jevrejima i Ciganima; BULAJIĆ, Tudjman's „Jasenovac Myth”. Genocide against Serbs, Jews and Gypsies; BULAJIĆ, The Independent State of Croatia, Jasenovac, The system of Ustasha death Camps; BULAJIĆ, Jasenovac. Ustaški logor smrti. „Srpski mit?”; BULAJIĆ, Jasenovac na sudu. Suđenje D. Šakiću i BULAJIĆ, Jasenovac. Balkan Auschwitz.

112 Usp. Spisak žrtava rata 1941-1945. Ustaški logor Jasenovac.

113 Usp. Jasenovac. Koncentracioni logor 1941-1945. Spisak ustaških žrtava identifikovanih do 30. X 1997.
} 
cjena umanjuju razmjere zločina u jasenovačkom logoru i da se radi o znatno većim brojkama. ${ }^{114}$

Mit o stotinama tisuća, pa i više od milijun žrtava logora Jasenovac, uglavnom Srba, urušio se 1998. kada je Bošnjački institut objavio poimenični popis Jasenovac. Žrtve rata prema podacima Statističkog zavoda Jugoslavije ${ }^{115}$, naime strogo čuvane podatke Komisije za popis žrtava rata SIV-a SFR Jugoslavije iz 1964. godine. Uza sva nagađanja o tome kako je Bošnjački institut došao do popisa pod embargom ${ }^{116}$, a i proturječne reakcije nakon njegova objavljivanja, mnogo toga postalo je očito i jasno. ${ }^{117}$ No megalomanska brojka od 700.000 žrtava logora Jasenovac ostala je ipak sveprisutna i jedina prihvatljiva u određenim srbijanskim krugovima.

Na Drugoj međunarodnoj konferenciji o logoru Jasenovac, održanoj u svibnju 2000. u Banjoj Luci, „da bi se postigla puna objektivna istina, pošto Hrvatska nije prihvatila bilateralni zajednički projekat istraživanja istine o logorima Jasenovac, posebno broja žrtava i nacionalnog sastava”, osnovana je Međunarodna komisija za utvrđivanje istine o Jasenovcu (The International Commission for the Truth on Jasenovac) sa sjedištem u Banjoj Luci ${ }^{118}$, koja postaje najuporniji zagovornik promicanja sumanutih navoda o logoru Jasenovac. ${ }^{119}$ Njihova „istina o Jasenovcu” „potvrđena” je 25. svibnja 2011. na Petoj međunarodnoj konferenciji o Jasenovcu Deklaracijom o genocidu Nezavisne Države Hrvatske nad Srbima, Jevrejima i Romima tokom Drugog svjetskog rata, objavljenom na osam jezika (srpskom, engleskom, ruskom, hebrejskom, francuskom, talijanskom, njemačkom i španjolskom). ${ }^{120}$ - Deklaracija o genocidu Nezavisne Države Hrvatske nad Srbima, Jevrejima i Romima tokom Drugog svjetskog rata Međunarodne komisije za utvrđivanje istine o Jasenovcu spominje i broj jasenovačkih žrtava: „[...] - imajući u vidu da se u hrvatskim

\footnotetext{
114 Usp. Jasenovac. Zbornik radova Prve međunarodne konferencije i izložbe o jasenovačkim koncentracionim logorima; Druga međunarodna konferencija Jasenovac - Sistem hrvatskih ustaških logora genocida (1941-1945); Jasenovac. Zbornik XI medunarodne konferencije o holokaustu; Jasenovac. Zbornik radova Četvrte međunarodne konferencije o Jasenovcu i Jasenovac. Peta Međunarodna konferencija o sistemu koncentracionih logora i stratišta hrvatske države za istrebljenje Srba, Jevreja i Roma u Drugom svjetskom ratu.

115 Jasenovac. Žrtve rata prema podacima Statističkog zavoda Jugoslavije.

116 Usp. MIRKOVIĆ, „Izdanja Muzeja žrtava genocida i građa o ljudskim gubicima u tim izdanjima”, 576.

117 Usp. KOČOVIĆ, Nauka, nacionalizam i propaganda, 143-144; KOVAČIĆ, „Jasenovac - žrtve rata prema podacima Statističkog zavoda Jugoslavije", 219-224.

118 Druga međunarodna konferencija Jasenovac - sistem hrvatskih ustaških logora genocida (19411945), 479. Usp. i „Međunarodna komisija za utvrđivanje istine o Jasenovcu”.

119 Usp. GEIGER, „Sumanuti i bolesni navodi i tvrdnje Međunarodne komisije za utvrđivanje istine o Jasenovcu", 13-17.

120 Deklaracija o genocidu Nezavisne Države Hrvatske nad Srbima, Jevrejima i Romima tokom Drugog svjetskog rata.
} 
javnim glasilima i kvazi istoriografskim radovima ne samo prećutkuju nego i radikalno umanjuju žrtve ovog genocida, naročito u Jasenovcu, i njihov broj svodi na samo 40.000 ubijenih Srba, Jevreja i Roma, kao što je to, u svojstvu istoričara, činio i prvi predsjednik Republike Hrvatske Franjo Tuđman; [...] - da je prilikom provođenja ovog genocida samo u jasenovačkom sistemu hrvatskih koncentracionih logora za istrebljenje Srba, Jevreja i Roma i neistomišljenika mučeno, pljačkano, silovano i potom ubijeno od strane Nezavisne Države Hrvatske: 700.000 Srba, 23.000 Jevreja i 80.000 Roma, jedino zbog toga što su pripadali drugom narodu, vjeri ili rasi; - da je Nezavisna Država Hrvatska bila jedina zemlja tokom Drugog svjetskog rata u kojoj su postojali koncentracioni logori za istrebljenje djece [...] i da je u njima prema nepotpunim istraživanjima stradalo 42.791 srpsko dijete, 5.737 romske djece i 3.710 jevrejske djece, $[. . .]^{\prime \prime 21}$

\begin{tabular}{|l|r|}
\hline \multicolumn{2}{|l|}{$\begin{array}{c}\text { Broj i nacionalna/etnička struktura žrtava logora Jasenovac prema Međunarodnoj } \\
\text { komisiji za utvrđivanje istine o Jasenovcu }\end{array}$} \\
\hline Srbi & 700.000 \\
\hline Romi & 80.000 \\
\hline Židovi & 23.000 \\
\hline
\end{tabular}

Nedvojbeno je posebno tijekom Drugoga svjetskog rata bila tragična sudbina srpske, romske i židovske djece u progonima stanovništva i u logorima NDH. Muzej žrtava genocida objavio je 2000. knjigu Dragoje Lukića Bili su samo deca. Jasenovac, grobnica 19.432 devojčice i dečaka, u kojoj se na temelju različitih pokazatelja ustvrđuje da je u logorima Jasenovac i Stara Gradiška život izgubilo 11.888 srpske, 5469 romske i 1911 židovske djece. ${ }^{122}$ - Unatoč često i žestokim raspravama o načinu utvrđivanja broja i sudbine srpske, romske i židovske djece u progonima stanovništva i u logorima NDH, ostalo je otvoreno i neriješeno pitanje koliko je djece život izgubilo u logorima NDH i logoru Jasenovac. Naime, i u Republici Srbiji i Republici Srpskoj, kao uostalom i u Hrvatskoj ${ }^{123}$, uporno se zastupaju različiti brojevi, čiji se pobornici pozivaju ili na popise ili na njima prihvatljive izračune ili procjene i ignoriraju drukčije pokazatelje.

Istaknutu ulogu u donošenju Deklaracije o genocidu Nezavisne Države Hrvatske nad Srbima, Jevrejima i Romima tokom Drugog svjetskog rata imali su srbijanski intelektualni autoriteti, akademici Srpske akademije nauka i umetnosti povjesničar Vasilije Krestić i pravnik Kosta Čavoški te pravnica prof.

121 Isto, 17, 18-19, 23, 25, 29, 31, 35, 36-37, 41, 43, 47, 49, 53, 55, 59, 61 .

122 Usp. LUKIĆ, Bili su samo deca. Jasenovac, grobnica 19.432 devojčice i dečaka.

123 Usp. VUKOVIĆ, Kako je nastao mit (o 20.101 ubijenom djetetu u jasenovačkom logoru). 
dr. Smilja Avramov ${ }^{124}$, uporni u promicanju teze o protusrpskoj usmjerenosti Katoličke crkve i genocidnosti Hrvata, odnosno hrvatske politike i stotinama tisuća žrtava logora Jasenovac, uglavnom Srba. Nezaobilazan je i antropolog prof. dr. Srboljub Živanović, istomišljenik i godinama blizak suradnik Milana Bulajića, predsjednik Međunarodne komisije za utvrđivanje istine o Jasenovcu i Fonda za istraživanje genocida, koji u svojim člancima, intervjuima i najblaže rečeno bolesnim javnim izlaganjima po Srbiji i drugdje te u knjigama posljednjih desetljeća zastupa i promiče brojku od najmanje 700.000 žrtava logora Jasenovac. ${ }^{125}$ Stoga je valjda za svoju knjigu Jasenovac. Odabrani radovi, članci, intervjui, govori i diskusije (2008.) i dobio nagradu Rastko Petrović Matice iseljenika Srbije „Za najbolje autentično djelo od nacionalnog značaja” 2009. godine. ${ }^{126}$

Potporu takvim nastojanjima iskazao je pobornik mistifikacija i zamagljivanja činjenica o ljudskim gubicima Jugoslavije, i Hrvatske, u Drugome svjetskom ratu, virtualni Jasenovac Research Institute, osnovan potkraj 90-ih godina zauzimanjem ponajprije Milana Bulajića te srpskoga lobija u Sjedinjenim Američkim Državama i uz pomoć nekih Židova u New Yorku koji podržavaju velikosrpska „viktimološka” nastojanja. Jasenovac Research Institute podatke Komisije za popis žrtava rata SIV-a SFR Jugoslavije iz 1964., ukupno poimenično utvrđenih nešto manje od 600.000, odnosno s kasnijim korekcijama i dopunama u MŽG-u ukupno 647.250 stradalih i žrtava tijekom Drugoga svjetskog rata na području Jugoslavije, na svojim mrežnim stranicama (www. jasenovac.org) uporno je godinama predstavljao kao popis žrtava (Victim's List) logora Jasenovac, ali tako da u popisu nije bila vidljiva rubrika s naznačenim mjestom smrti. Ponavljam, da se radi o popisu iz 1964. upozorio sam u Časopisu za suvremenu povijest 2011. i 2013. godine. ${ }^{127}$ Ali neki neupućeni i zbunjeni korisnici, pa i istraživači, u Hrvatskoj to nisu shvatili. ${ }^{128}$ Tek desetak godina poslije Jasenovac Research Institute na svojim mrežnim stranicama donosi jasno i kratko uvodno objašnjenje da se radi o popisu iz 1964. godine. Naravno, uz napomenu koliko je žrtava logora Jasenovac Zemaljska komisija

\footnotetext{
124 Usp. Jasenovac. Peta Međunarodna konferencija o sistemu koncentracionih logora i stratišta hrvatske države za istrebljenje Srba, Jevreja i Roma u Drugom svjetskom ratu i Deklaracija o genocidu Nezavisne Države Hrvatske nad Srbima, Jevrejima i Romima tokom Drugog svjetskog rata.

125 Usp. ŽIVANOVIĆ, Jasenovac i ŽIVANOVIĆ, Jasenovac 2.

126 Usp. „Živanoviću nagrada za knjigu 'Jasenovac”.

127 Usp. GEIGER, „Ljudski gubici Hrvatske u Drugom svjetskom ratu koje su prouzročili 'okupatori i njihovi pomagači'. Brojidbeni pokazatelji”, 724 i GEIGER, „Brojidbeni pokazatelji o žrtvama logora Jasenovac, 1941.-1945., 223.

128 Usp. primjerice: PSD, „Slaven Letica: Moj brat, koji je umro u El Shattu, pretvoren je u žrtvu Jasenovca”; KLJAKOVIĆ-ŠANTIĆ, Jasenovac - enigma holokausta, 23-62 i MATKOVIĆ, „Kako je nastao i razvijao se velikosrpski jasenovački mit i zašto je ostao službeni, državni kult, čak i u današnjoj Hrvatskoj?", 31.
} 
Hrvatske za utvrđivanje zločina okupatora i njihovih pomagača procijenila 1946. godine. ${ }^{129}$

Primjetno je da srbijanska historiografija i publicistika izvještaj Zemaljske komisije Hrvatske za utvrđivanje zločina okupatora i njihovih pomagača naslovljen Zločini u logoru Jasenovac, prepun najblaže rečeno izmišljenih i pretjeranih tvrdnji, u kojemu je ustvrđeno da je u logoru Jasenovac život izgubilo 500.000 do 600.000 osoba, ${ }^{130}$ uzima kao vjerodostojan, kao uostalom i mnogobrojne u poraću druge naprečac izrečene navode i tvrdnje o logoru Jasenovac. Kao nezaobilazan i vjerodostojan izvor, izvještaj Zemaljske komisije Hrvatske za utvrđivanje zločina okupatora i njihovih pomagača o logoru Jasenovac objavljen je 2000. dvojezično, na hrvatskom i engleskom jeziku, te je tako namijenjen i za inozemnu upotrebu. ${ }^{131}$

Uvažavajući sve pokazatelje i pretpostavke nezaobilazne u izračunavanju ljudskih gubitaka Jugoslavije u Drugome svjetskom ratu, demografski gubici mogu iznositi oko 2 milijuna, a stvarni gubici oko 1 milijun. Znatnija povećanja demografskih i stvarnih gubitaka Jugoslavije u Drugome svjetskom ratu najčešće su prilagođavanje metodologije izračunavanja za potrebe prihvatlji$v i h$ demografskih i stvarnih gubitaka pojedine nacionalne/etničke skupine. ${ }^{132}$ Upravo takvu metodologiju primijenio je dr. Životije Đorđević u svojoj knjizi Gubici stanovništva Jugoslavije u Drugom svetskom ratu (1997.), u kojoj osporava ponajprije izračune Bogoljuba Kočovića i Vladimira Žerjavića, ali i sve slične izračune prije i nakon njih dvojice o demografskim i stvarnim ljudskim gubicima Jugoslavije tijekom Drugoga svjetskog rata. Đorđević se jasno određuje i navodi različite pokazatelje o razmjerima stradanja Srba u NDH te ustvrđuje da je jasenovačko „stratište” „progutalo stotine hiljada nevinih žrtava, lišenih života na najsvirepiji način” i da Velimir Terzić133 ima pravo kada tvrdi da je u Jasenovcu samo do kraja 1943. život izgubilo najmanje 600.000 ljudi, „najviše Srba”. ${ }^{134}$ - Recenzent ove Đorđevićeve knjige poznati je srpski statističar akademik Vasilije Krestić. Jedan od recenzenata Đorđevićeva „životnog dela”, njegove opsežne knjige Satiranje srpstva u 19. i 20. veku (2012.) ${ }^{135}$, jest prof. dr.

\footnotetext{
129 Usp. „Victim’s List”.

130 Usp. Zločini u logoru Jasenovac, 38.

131 Usp. Zemaljska komisija Hrvatske za utvrđivanje zločina okupatora i njihovih pomagača, „Zločini u logoru Jasenovac" = Croatian State Commission for Establishing Crimes of Occupying Forces and Their Assistants, „Crimes in the Jasenovac Camp”.

132 Usp. GEIGER, „Brojidbeni pokazatelji o ljudskim gubicima Hrvatske u Drugom svjetskom ratu i poraću", 58-60 i ondje navedena literatura.

133 TERZIĆ, Slom Kraljevine Jugoslavije 1941 - uzroci i posledice, 611.

134 ĐORĐEVIĆ, Gubici stanovništva Jugoslavije u Drugom svetskom ratu, 25, 38.

135 ĐORĐEVIĆ, Satiranje srpstva u 19. i 20. veku.
} 
Smilja Avramov, a u njoj dr. Đorđević s jednakim nadahnućem razglaba i o razmjerima srpskih stradanja u NDH i o broju jasenovačkih žrtava.

Na Okruglom stolu Udruženja zatočenika i potomaka zatočenika logora genocida u Nezavisnoj Državi Hrvatskoj 1941-1945. Odgovornost države Hrvatske za izvršeni genocid nad srpskim narodom i drugim narodima u periodu 1941-1945. i 1991-1995. godine, održanom početkom ožujka 2007. u Beogradu, okupila se „krema” srpskih nacionalista zastupnika teze o protusrpskoj usmjerenosti Katoličke crkve i genocidnosti Hrvata i 700.000 ili barem najmanje nekoliko stotina tisuća žrtava logora Jasenovac, predvođena akademikom Krestićem. Govornici na Okruglom stolu, mr. Lazar Lukajić, dr. Milan Bulajić, mr. Dragoljub Acković, Aleksandar S. Jovanović, Milisav Sekulić, Smilja Tišma i drugi, u izlaganjima su iznosili općepoznate i već nebrojeno puta spominjane brojke o žrtvama logora Jasenovac. Naravno, svi sudionici Okrugloga stola bili su složni da su u Jasenovcu ubijene stotine tisuća, odnosno 700.000 osoba, uglavnom Srba. ${ }^{136}$ Najistaknutiji među izlagačima, dr. Bulajić, ustvrdio je: „Broj od 700000 žrtava nije izraz 'srpskog mita o Jasenovcu'. Broj 700000 navodile su hrvatske institucije i najistaknutiji hrvatski predstavnici” (što je i danas omiljeni argument srpskih nacionalista za 700.000 žrtava logora Jasenovac), te je prozvao sve one u Hrvatskoj, od Franje Tuđmana nadalje, a i u Republici Srbiji i inozemstvu, koji spore da su u Jasenovcu život izgubile stotine tisuća osoba. Za izjavu Slavka Goldsteina na komemoraciji u Jasenovcu u travnju 2005. da se „sa velikom sigurnošću može tvrditi” da se broj žrtava logora Jasenovac „kreće između 80 i 100 tisuća” kazuje da je „minimiziranje kleroustaških zločina, otvoreni revizionizam!”. ${ }^{137}$ Po tko zna koji put Bulajić je ponovio istu „priču” o ustaškim zločinima u NDH i razmjerima zločina u logoru Jasenovac i u zborniku Zatiranje Srba u Hrvatskoj (2008.) ${ }^{138} \mathrm{U}$ istom zborniku prof. dr. Mirko Zurovac ustvrđuje da je „umoreno [je] najsvirepijim metodama preko milion Srba u tzv. NDH” i: „Koncentracioni logori Jasenovac i Stara Gradiška nadilaze sve ono što bi i najpokvareniji ljudski um mogao da zamisli. Strašne patnje i likvidacije više stotina hiljada ljudi u tim logorima smrti." 139

O broju jasenovačkih žrtava svatko se poziva na njemu „relevantne” izvore i podatke. Jovan Mirković (MŽG) u predgovoru svoje knjige Objavljeni izvori i literatura o jasenovačkim logorima (2000.) drži se starih, od komunističkoga jugoslavenskog režima određenih i promicanih brojeva i ustvrđuje: „Koncen-

136 Usp. Odgovornost države Hrvatske za izvršeni genocid nad srpskim narodom i drugim narodima u periodu 1941-1945. i 1991-1995. godine.

137 BULAJIĆ, „Različiti podaci o broju stradalih u sistemu logora genocida Jasenovac sa posebnim osvrtom na stradanje Roma”, 34-44.

138 BULAJIĆ, „Politika genocida nad Srbima kroz sistem logora Jasenovac”, 213-233.

139 ZUROVAC, „Genocid pod plaštom 'demokratije”, 257, 258-259. 
tracioni logor Jasenovac je po broju ubijenih zatočenika bio najveće gubilište na tlu Jugoslavije. Od 1706000 izgubljenih života u ratu nekoliko stotina hiljada je ubijeni u Jasenovcu." Poziva se na radove Anđelka Barbića i Antuna Miletića ${ }^{140}$ te objašnjava da se u literaturi podaci o broju žrtava logora Jasenovac „kreću u relaciji od 400000 do 800 000. Najčešće se navodi podatak o 700000 stradalih”. Mirković napominje da „Ima i minimizatora” i spominje kardinala Franju Kuharića (40.000), akademika Ivana Supeka i dr. Franju Tuđmana (50.000), „pa do onih koji govore preko 1000 000” i spominje Velimira Terzića i Radomira Bulatovića. „I jedni i drugi ističu u prvi plan žrtve svoje nacionalne pripadnosti”, zaključuje Mirković, čime očito sugerira da je njegov navod da je u Jasenovcu život izgubilo „nekoliko stotina hiljada” utemeljen i objektivan. $^{141}$

Zbrajajući pokazatelje revidiranog - djelomično dopunjenog popisa Komisije za popis žrtava rata SIV-a SFR Jugoslavije iz 1964., tadašnje podatke MŽG-a i poimenične i brojčane pokazatelje iz različitih provjerljivih i neprovjerljivih izvora, povjesničar Antun Miletić u svojoj je knjizi NDH - Koncentracioni logor Jasenovac 1941-1945., objavljenoj u Beogradu 2010., olako zaključio da je u logoru Jasenovac život izgubila najmanje 146.401 osoba. ${ }^{142} \mathrm{U}$ žrtvoslovu Ubijeni u koncentracionom logoru Jasenovac 1941-1945., objavljenom godinu poslije, Miletić je brojke neznatno korigirao, pa je u logoru Jasenovac život izgubilo najmanje 146.248 osoba (80.192 žrtava prema poimeničnom popisu te 66.056 žrtava utvrđenih brojem - NN, bez imena i prezimena), od čega 97.972 Srba, 26.535 Roma, 15.707 Židova i 3668 Hrvata. ${ }^{143}$ Žrtvoslov Ubijeni u koncentracionom logoru Jasenovac 1941-1945., prepun osoba navedenih dva ili više puta, osoba koje ondje ne spadaju ili nepostojećih osoba i previše NN osoba, i brojke do kojih je došao iskaz su njegovih i inih želja, a ne utemeljenih pokazatelja, kao i kod prijašnjih njegovih procjena da je u logoru Jasenovac „ubijeno [je] više stotina hiljada ljudi, žena i dece”. Postalo je jasno i da je netočna Miletićeva tvrdnja koju je izrekao na Međunarodnom znanstvenom skupu Genocid nad Srbima u II svetskom ratu, održanom u Beogradu u listopadu 1991., da bi broj jasenovačkih žrtava prema dotadašnjim poimeničnim pokazateljima trebao iznositi najmanje 186.000. Naime, tada je ustvrdio da i nepotpuni popis „žrtava ustaškog genocida” „do sada utvrđen imenom i prezimenom iznosi više od 280.000 lica, od kojih su najmanje dve trećine stradale

\footnotetext{
140 BARBIĆ, „Prilozi problematici istraživanja broja žrtava u KCL Jasenovac od 1941. do 1945., 81-97 i MILETIĆ, Koncentracioni logor Jasenovac 1941-1945. Dokumenta, knj. I.

141 MIRKOVIĆ, Objavljeni izvori i literatura o jasenovačkim logorima, 7.

142 Usp. MILETIĆ, NDH - Koncentracioni logor Jasenovac 1941-1945., 123.

143 Usp. MILETIĆ, Ubijeni u koncentracionom logoru Jasenovac 1941-1945., 27.
} 
u jasenovačkim logorima”, te da su „iluzorne sve političke manipulacije minimizatora počinjenih zločina u koncentracionom logoru Jasenovac”. ${ }^{144}$

Da bi okupljanja istomišljenika dobila privid ozbiljnoga i znanstvenoga pristupa, osnivaju se „međunarodne komisije” i održavaju „međunarodne konferencije”. Članovi tih komisija i sudionici tih konferencija u pravilu su istomišljenici. - Što se tiče broja jasenovačkih žrtava, nisu „podbacile” ni Prva, a ni Druga međunarodna konferencija znakovitoga naziva Holokaust nad Srbima, Jevrejima i Romima u Drugom svetskom ratu, održane u siječnju 2014. i siječnju 2015. u Beogradu u organizaciji Univerziteta „Union - Nikola Tesla” iz Beograda, na kojima su se okupili srbijanski znalci raznih struka, uz nekoliko istomišljenika iz inozemstva. ${ }^{145}$ - Prema Radomiru Smiljaniću, „pravniku, novinaru, književniku, etičaru", kako se sam predstavio, u izlaganju na Prvoj konferenciji naslovljenom „Prekrajanje istorije u funkciji ubijanja Srbije”, dao je svoje viđenje svega i svačega, do „ekstremnog velikohrvatskog nacionaliste Franje Tuđmana”, i jedini spominjao brojeve žrtava logora Jasenovac: u NDH „se išlo za potpunom likvidacijom Roma, Srba i Jevreja. Sve je učinjeno da se do kraja satru i zbrišu s lica zemlje. U zverstvima i po sadizmu prema Romima, Srbima i Jevrejima, ustaše su gotovo nadmašili svoje nacističko-fašističke gospodare. Nekadašnji logor smrti Jasenovac je strašno svedočanstvo i grozna optužba. Među 1.200.000 srpskih žrtava 80.000 je Roma i 24.000 Jevreja." ${ }^{146}$ Dakle, Jasenovac ni manje ni više: milijun i 200 tisuća. Govorimo i pišemo što nas je volja jer međunarodne konferencije valjda za to i služe. Pa se i na Drugoj međunarodnoj konferenciji Holokaust nad Srbima, Jevrejima i Romima u Drugom svetskom ratu mogao saznati niz „pouzdanih” podataka i o razmjerima ustaških zločina u NDH i o broju jasenovačkih žrtava. ${ }^{147}$

Da bi dokazali broj od nekoliko stotina tisuća žrtava logora Jasenovac, u Srbiji se rado pozivaju i na njemačke procjene iz vremena Drugoga svjetskog rata, primjerice general-majora SS-a Ernsta Ficka u pismu Heinrichu Himmleru u svibnju 1944., gdje je iznio da su ustaše „poznate po tome što su oko 6-700.000 (politički) drugačije nastrojenih odveli u koncentracione logore i 'zaklali' na balkanski način”. ${ }^{148}$ Usto, da bi brojka od najmanje 700.000 žrtava

\footnotetext{
144 MILETIĆ, „O bilansu smrti u koncentracionom logoru Jasenovac (1941-1945)”, 223.

145 Usp. Prva medunarodna konferencija Holokaust nad Srbima, Jevrejima i Romima u Drugom svetskom ratu. Zbornik radova i Druga medunarodna konferencija Holokaust nad Srbima, Jevrejima i Romima u Drugom svetskom ratu. Zbornik radova.

146 SMILJANIĆ, „Prekrajanje istorije u funkciji ubijanja Srbije”, 83.

147 Usp. primjerice: MRĐA, „Stradanje srpske, romske i jevrejske dece u logorima NDH”, 91 i STIPANKOV, M. KALIČANIN, Z. KALIČANIN, „Ustaški koncentracioni logori u NDH”, 186.

148 Usp. primjerice: BULAJIĆ, „Jasenovački mit” Franje Tuđmana - Genocid nad Srbima, Jevrejima i Ciganima, 57 ili BULAJIC, Tudjman's „Jasenovac Myth”. Genocide against Serbs, Jews and Gypsies, 50; MILETIĆ, „Prilog utvrđivanja imenom broja usmrćenih u koncentracionom logoru
} 
logora Jasenovac bila uvjerljiva, a i opis logora potpun, u Republici Srbiji i Republici Srpskoj, ali i drugdje, ponovno su uskrsnule i u optjecaj puštene stare izmišljotine o „srbosjeku” i „takmičenjima ustaša u klanju”, „Pićilijevoj peći” i „proizvodnji sapuna od ljudskih leševa”. ${ }^{149}$

U Srbiji, kao i u Hrvatskoj, ponavljam, svatko misli da je pozvan meritorno raspravljati o logoru Jasenovac. - Novinar i publicist Jaša Almuli u svojoj knjizi Jevreji i Srbi u Jasenovcu, objavljenoj 2009. u izdanju uglednoga srbijanskog nakladnika Službeni glasnik, spominje procjene u Jasenovcu ubijenih Židova, Roma i Srba te broj logorskih žrtava djece. Piše i da su na bosanskoj strani „nađene 162 ogromne masovne grobnice”, ali ne spominje koliko je u tim masovnim grobnicama pronađeno posmrtnih ostataka žrtava, i samo nas izvještava: „Istraživanja će se nastaviti.” Iako Almuli piše da se ne osjeća sposobnim odrediti broj žrtava „jer je to složena tema koja traži stručno znanje i veliki rad”, nedvojbeno je zastupnik teze da je u Jasenovcu život izgubilo 500.000 do 700.000 ljudi. Kao i drugi zastupnici takvih brojeva žrtava, proziva ponajprije Franju Tuđmana, ali i druge „minimizatore”. Ustvrđuje i da „postoje tendencije da se nešto uvećan broj popisanih žrtava prikaže kao konačan, pokazale su procene nekih ljudi u Hrvatskoj, [...]” te proziva ponajprije „izdavača i publicistu” Slavka Goldsteina i „njegovog sina, istoričara” Ivu Goldsteina. Jedini koga srbijanski pristaše brojke od 700.000 jasenovačkih žrtava, pa i Almuli ${ }^{150}$, uvažavaju u Hrvatskoj jest Salamon Jazbec iz Margelova instituta u Zagrebu, ponajprije zbog njegova otvorenoga protivljenja „minimiziranju” jasenovačkih žrtava i prozivanju zbog toga Slavka i Ive Goldsteina. ${ }^{151}$

$\mathrm{U}$ izdanju samozvanoga Instituta za istraživanje srpskih stradanja u XX veku (prije: Centar za istraživanje zločina nad srpskim narodom) iz Beograda objavljena je 2016. knjiga Jasenovac, Kozara, Jadovno svestrane srbijanske književnice Biljane Živković, u kojoj ustvrđuje da je u „najgorem i najcrnjem srpskom stratištu u Nezavisnoj Državi Hrvatskoj”, u logoru Jasenovac, „zverski ubijeno preko 700.000 naših sunarodnika i na desetine hiljada Roma, Jevreja, muslimana..."152 Književnica navodi niz podataka i poziva se na različite autore i svjedoke - među kojima i Srboljuba Živanovića i njegovu knjigu Jasenovac, kao i Lazara Lukajića i njegovu knjigu Fratri i ustaše kolju $u^{153}$ u izdanju Fonda

Jasenovac”, 54; JOVANOVIĆ, „Šta se znalo za vreme II svetskog rata o broju žrtava u NDH, prema podacima Saveznika i izvršiocima zločina", 67-71 i ALMULI, Jevreji i Srbi u Jasenovcu, 524.

149 Usp. primjerice: ŽIVANOVIĆ, Jasenovac; ŽIVANOVIĆ, Jasenovac 2; STIPANKOV, M. KALIČANIN, Z. KALIČANIN, „Ustaški koncentracioni logori u NDH”, 186; ALMULI, Jevreji i Srbi u Jasenovcu i JOVANOVIĆ, Beg iz jasenovačkog pakla.

150 ALMULI, Jevreji i Srbi u Jasenovcu, 30-31, 523-525.

151 Usp. JAZBEC, Magnissimum crimen, 577-615.

152 ŽIVKOVIĆ, Jasenovac, Kozara, Jadovno, 27.

153 LUKAJIĆ, Fratri i ustaše kolju - zločinci i svedoci. 
za istraživanje genocida, Beograd - zahvaljujući kojima „lako i nedvojbeno” potvrđuje razmjere ustaških zločina u NDH i svoje opise logora Jasenovac i broj jasenovačkih žrtava. - Uz mnogobrojne druge istaknute Srbe, ekstremne nacionaliste, da bi potvrdio svoja stajališta, poziva se opširno na pisanja Antuna Miletića, Vladimira Dedijera i Milana Bulajića, a i drugih sličnih stajališta o ustaškim zločinima i jasenovačkim žrtvama, i dr. Vojislav Šešelj u svojoj nadasve poznatoj knjizi Rimokatolički zločinački projekat veštačke hrvatske nacije (2007.). ${ }^{154}$

No osebujna stajališta i tumačenja nisu svojstvena samo amaterima, nego i istaknutim srpskim povjesničarima i političarima. - Potkraj prosinca 2019. povjesničar i arhivist Jovan Pejin, do pada Slobodana Miloševića s vlasti direktor Arhiva Srbije, izjavio je: „Skrivanje zločina bio je deo programa 'bratstva-jedinstva' svih naroda i narodnosti jedinstvene KPJ/SKJ”, a glavni je uzrok u "halucinaciji kroatokomunista bliskih frankovcima o slavnoj hrvatskoj prošlosti” te Andrija Hebrang, Vladimir Bakarić i napose Ivan Krajačić Stevo, sve do Josipa Broza Tita i „poslušnih anacionalnih srpskih komunista koji su prihvatili nacionalni program Partije bez rezerve [...].” Pejin tvrdi: „Skriva se i dalje istina sa činjenicama da je izvršen genocid nad Srbima i da je sistem logora Jasenovac bio izgrađen i namenjen rečenoj nameri” te ustvrđuje da je „prema nemačkim izvorima” u Jasenovcu ubijeno „oko 700000 ljudi, žena i dece". ${ }^{155}$ Opsjednutost srbijanskih nacionalista nadrealnom pričom da je Tito uništio dokumente o Jasenovcu odnosno predao ih Vatikanu ne gubi na intenzitetu. - U rujnu 2019. u srbijanskim je medijima objavljena tvrdnja dr. Borisava Jovića, predsjednika Predsjedništva SFR Jugoslavije 1989. - 1991., da je Tito „u najvećoj tajnosti prebacio u Vatikan dokumentaciju sa najgorim dokazima o stravičnim ustaškim zločinima u Jasenovcu”. To je, prema Joviću, učinio „uz pomoć odanog saradnika, hrvatskog funkcionera Ivana Steve Krajačića, a jedini koji je za to saznao bio je Aleksandar Leka Ranković, tada potpredsednik države, zbog čega je ekspresno smenjen i oteran u potpunu ilegalu. Zvanično obrazloženje bilo je da je prisluškivao Tita, u šta gotovo niko ni tada nije poverovao". Ova umotvorina ponegdje je objavljena uz istaknuti navod da je „700 hiljada Srba, Jevreja i Roma (neki smatraju i više) pobijeno u Jasenovcu". ${ }^{156}$

Ni srbijanski udžbenici povijesti koji su u školskoj uporabi nisu se udaljili od mitskih brojeva jasenovačkih žrtava, pa i dalje navode, uz živopisne opise logora Jasenovac, pozivajući se na procjenu Državne komisije za utvrđivanje zločina okupatora i njihovih pomagača iz 1945., da je u Jasenovcu život iz-

154 Usp. ŠEŠELJ, Rimokatolički zločinački projekat veštačke hrvatske nacije, 793-885.

155 DIMITRIJEVIĆ, „Jovan Pejin: Jasenovac u srpskoj istoriji”.

156 Usp. primjerice: MITROVIĆ, „Tito dokumentaciju o Jasenovcu tajno prebacio u Vatikan!”. 
gubilo 600.000 osoba $^{157}$, ili pak pozivajući se na procjenu Zemaljske komisije Hrvatske za utvrđivanje zločina okupatora i njihovih pomagača iz 1946., da je u Jasenovcu život izgubilo 500.000 do 600.000 osoba, a da se u historiografskoj literaturi najčešće spominje 700.000 ubijenih $^{158}$. Tek iznimno srbijanski udžbenici povijesti donose uz navedene najčešće spominjane procjene koliko je do sada poimenično „evidentiranih” žrtava logora Jasenovac. ${ }^{159}$

Primjetno je da o ustaškim zločinima u NDH i žrtvama logora Jasenovac u Srbiji posljednjih godina pišu i profesionalni povjesničari koji se tim pitanjima nikada nisu bavili niti je to područje njihova znanstvenoga rada. Prof. dr. Mira Radojević (Odeljenje za istoriju Filozofskoga fakulteta u Beogradu) u knjizi Jasenovac, u suautorstvu s akademikom Vasilijem Krestićem ${ }^{160}$, objavljenoj 2017. u izdanju Srpske akademije nauka i umetnosti, u svojem dijelu knjige, naslovljenom „Jasenovac, logor smrti (1941-2016)”, u nabrajanju mnogobrojnih „pouzdanih” navoda znanih i manje znanih osoba o broju žrtava logora Jasenovac ne donosi ništa novo, ništa što već nije stotine, pa i tisuću puta objavljeno, i ponavlja općepoznate „istine”. Za izvještaj Zemaljske komisije Hrvatske za utvrđivanje zločina okupatora i njihovih pomagača iz 1946. prepun nevjerojatnih, pa i apsurdnih navoda i tvrdnji, u kojemu je zaključeno da je u logoru Jasenovac život izgubilo 500.000 do 600.000 osoba, ustvrđuje da su se na "njegove rezultate pozivali mnogi potonji istoričari, prvenstveno oni koji su u svom radu bili rukovođeni težnjom za objektivnijim pristupom". ${ }^{161}$ - Ne mogu se ne složiti s Radojević da se „U slučaju Jasenovca danas [se] suočavamo s novim izazovima, prvenstveno još jednim talasom nastojanja dela hrvatske istoriografije, publicistike i politike da u atmosferi jačanja krajnje desničarskih ideja žrtve ovog logora brojčano što više umanje, a nacionalno relativizuju" ${ }^{162}$ - Na sreću svih nas, Republika Srbija prepuna je povjesničara i drugih istraživača koji pristupaju znanstveno i „utemeljeno” pišu o NDH, ustaškim zločinima i žrtvama logora Jasenovac.

Izraelski povjesničar prof. dr. Gideon Greif, nova zvijezda na srbijanskom historiografskom nebu, autor opskurne knjige Jasenovac - Auschwitz of the Balkans ${ }^{163}$, objavljene u Beogradu potkraj 2018., u kojoj je znalački pobrojio da su ustaše izmislili ukupno 57 metoda sadističkoga ubijanja svojih žrtava,

\footnotetext{
157 VAJAGIĆ, STOŠIĆ, Istorija 8. Udžbenik za osmi razred osnovne škole, 159.

158 LJUŠIĆ, DIMIĆ, Istorija za osmi razred osnovne škole, 179.

159 ĐURIĆ, PAVLOVIĆ, Istorija za osmi razred osnovne škole, 153 i ĐURIĆ, PAVLOVIĆ, Istorija za treći razred gimnazije prirodno-matematičkog smera i četvrti razred gimnazije opšteg i društveno-jezičkog smera, 206.

160 KRESTIĆ, RADOJEVIĆ, Jasenovac.

161 RADOJEVIĆ, „Jasenovac, logor smrti (1941-2016)”, 79, 80, 84, 85.

162 Isto, 91, 92.

163 GREIF, Jasenovac - Auschwitz of the Balkans.
} 
ponajprije Srba, ustvrdio je da je „minimalan broj žrtava Jasenovca 700.000, a možda i više, možda i 800.000 Srba, Jevreja i Roma, nedužnih ljudi”. ${ }^{164}$ - Greif i njegova tumačenja ustaških zločina počinjenih u NDH i megalomanske brojke o žrtvama logora Jasenovac koje promiče imaju svekoliku podršku vladajuće državne srpske politike i mnogobrojnih prorežimskih medija. U dnevnom listu Politika u veljači 2019. Greif je u svojem podlistku „Jasenovac - Aušvic Balkana" iznio i mišljenje o kontroverzama o broju žrtava te ustvrdio da se brojka od 700.000 žrtava logora Jasenovac „može [se] smatrati realističnom”. Da bi potkrijepio tu svoju tvrdnju, pobrojio je brojne komisije, autore i knjige, a sve one koji su osporavali ili i dalje osporavaju brojku od 700.000 proglašava revizionistima. Greif napominje: „s druge strane pojedini hrvatski istoričari i političari su pokušali da umanje ove brojke. Tako je, naprimer, hrvatski predsednik iz devedesetih godina dvadesetog veka, Franjo Tuđman tvrdio da broj žrtava ne premašuje 3.000 do 4.000 . Jasenovački memorijalni centar u Hrvatskoj [JUSP Jasenovac] je u poslednjim decenijama smanjio broj žrtava na 83.000.” Greif smatra da je i prof. dr. Ivo Goldstein revizionist i proziva ga da je „na liniji [je] narativa države Hrvatske - 83.000 žrtava”. ${ }^{165}$ - Greif u svojem dokazivanju broja jasenovačkih žrtava ne samo da vidi što mu je volja i pronalazi „dokaze” gdje mu je volja, nego ima i problema s nulama, ili ih ima previše ili premalo. Naime, dr. Tuđman u svojim člancima, knjigama i javnim istupima nikada nije spominjao brojku od 3000 do 4000 jasenovačkih žrtava.

Srpskim nacionalistima i njihovim istomišljenicima iz inozemstva, okupljenima mahom u Međunarodnoj komisiji za utvrđivanje istine o Jasenovcu, revizionisti su svi oni, od Franje Tuđmana do Slavka i Ive Goldsteina, koji ne podržavaju brojku od 700.000 ili barem 500.000 do 600.000, ako već ne milijun i više jasenovačkih žrtava, kao i osebujne opise logora Jasenovac, kojima je uporno i neprekidno do danas u javnim istupima sklona srpska politika, većina srpskih medija i znatan dio srpskih povjesničarskih i znanstvenih krugova. U Republici Srbiji i Republici Srpskoj, gdje i dalje prevladava megalomanski navod o najmanje 700.000 žrtava logora Jasenovac, one koji zastupaju manje i znatno manje brojeve jasenovačkih žrtava proglašava se „minimizatorima” srpskih stradanja i ustaškoga genocida. Malobrojni srbijanski povjesničari i istraživači koji nisu skloni nestvarnim brojevima žrtava logora Jasenovac u srbijanskim ekstremnim nacionalističkim krugovima proglašeni su „izdajicama srpstva".

\footnotetext{
164 [GRAJF], „U Jasenovcu je ubijeno možda i 800.000 Srba, Jevreja i Roma, o tome se NE SME ĆUTATI”.

165 GRAJF, „Jasenovac - Aušvic Balkana. Kontroverze o broju žrtava”, 19.
} 
„Minimizatori” broja žrtava logora Jasenovac u Republici Srbiji nakon raspada SFR Jugoslavije

Na poticaj MŽG-a, Savezni zavod za statistiku Savezne Republike Jugoslavije 1992. objavio je (odnosno umnožio u nekoliko primjeraka za internu upotrebu) separat popisa Komisije za popis žrtava rata SIV-a SFR Jugoslavije iz 1964. za logore Jasenovac i Stara Gradiška Spisak žrtava rata 1941-1945. Ustaški logor Jasenovac, koji donosi podatke za ukupno 59.188 (Jasenovac 49.602 i Stara Gradiška 9586) žrtava, od čega je najviše Srba: 33.944, zatim Židova: 9044, Hrvata: 6546 i Roma: $1471{ }^{166}$ Taj su popis zatim sljedećih godina u MŽG-u revidirali - dopunjavali i objavili 1997. te s dopunama donosi podatke za 78.163 osobe koje su život izgubile u logorima Jasenovac i Stara Gradiška, od čega je popisano najviše žrtava Srba: 47.123, zatim Židova: 10.521, Hrvata: 6281 i Roma: 5836.167 - Dakle, za pet godina revizijom - dopunom popisa žrtava logora Jasenovac iz 1964. od 59.188 došlo se do 78.163 - povećanje za 18.975 osoba, naime za više od $32 \%$.

Neki su, poput Bogoljuba Kočovića, kojemu se ne može zanijekati znanstvena ozbiljnost, bili krajnje sumnjičavi prema tom znatnom poimeničnom povećanju broja jasenovačkih žrtava. ${ }^{168} \mathrm{Ne}$ bez razloga, jer odakle pedeset godina nakon Drugoga svjetskog rata i trideset godina nakon popisa iz 1964. toliko novih imena žrtava? Na temelju čega su i kako provjereni ti novi poimenični podaci, ili su samo upisivani u poimeničnu bazu jer u najvećem broju slučajeva nije ni bila moguća provjera vjerodostojnosti? - No, kako je prije napomenuto, uza sva nastojanja, revizija - dopuna poimeničnoga popisa žrtava logora Jasenovac iz 1964. napravljena u MŽG-u nije potvrđivala navode direktora Muzeja dr. Bulajića i njegovih mnogobrojnih istomišljenika, ponajprije u Republici Srbiji i Republici Srpskoj, o nekoliko stotina tisuća i najčešće 700.000 jasenovačkih žrtava. A kao konačni rezultat, i revizija - dopuna popisa žrtava logora Jasenovac iz 90-ih godina, a i kasnije dopune sve do danas, prema srpskim ekstremnim nacionalističkim stajalištima „minimiziranje” je broja jasenovačkih žrtava. - Objašnjavajući poslije „neuspjeh” revizije - dopune poimeničnoga popisa tijekom 90-ih godina u MŽG-u, dr. Bulajić je tvrdio: „Da je bilo podrške, vrlo brzo bismo došli do sto hiljada, što bi predstavljalo minimum minimuma broja žrtava, s obzirom da postoje sela i čitava područja potpuno uništena, bez svjedoka, posebno kada su u pitanju

\footnotetext{
166 Usp. Spisak žrtava rata 1941-1945. Ustaški logor Jasenovac.

167 Usp. Jasenovac. Koncentracioni logor 1941-1945. Spisak ustaških žrtava identifikovanih do 30. X 1997.

168 Usp. KOČOVIĆ, Nauka, nacionalizam i propaganda, 145.
} 
Romi."169 - Nedvojbeno, na poimeničnom popisu iz 1964. nisu navedeni oni za koje nitko nije mogao dati podatke, i nije riječ samo o Romima, ali su na tom popisu mnogobrojne žrtve iskazane dva ili više puta, neke su žrtve navedene s nepotpunim ili netočnim podacima, a mnogi, ponajprije Romi, navedeni su samo kao NN, bez imena i prezimena. Usto, kao žrtve logora Jasenovac i Stara Gradiška navedeni su i mnogi koji su prošli kroz te logore, ali su nedvojbeno život izgubili drugdje. ${ }^{170}$ No temeljno je pitanje koliko je revizija popisa iz 1964. u MŽG-u tijekom 90-ih godina uspješno „pročistila” takve, odnosno je li ustvari naglasak revizije bio na dopuni popisa. - Prava je pak šteta da ni danas na mrežnim stranicama MŽG-a nema revidiranog - djelomično dopunjenog popisa za logore Jasenovac i Stara Gradiška jer bi mogućnost uvida i provjere podataka otklonila svaku sumnju u vjerodostojnost toga poimeničnog popisa.

Ne treba zanemariti da je u Srbiji i 90-ih godina i poslije bilo i ozbiljnih nastojanja u osporavanju utemeljenosti i razobličavanju dugogodišnjih „megalomanskih” navoda o ljudskim gubicima Jugoslavije u Drugome svjetskom ratu, a i žrtvama Srba u NDH, pa time i u logoru Jasenovac. Riječ je ponajprije o pisanjima statističara prof. dr. Srđana Bogosavljevića. ${ }^{171}$ Takva nastojanja, kao i napokon objavljivanje knjige Bogoljuba Kočovića o ljudskim gubicima Jugoslavije u Drugome svjetskom ratu u Srbiji 2005. godine, ${ }^{172}$ nisu mogla, niti mogu danas, pokolebati mnogobrojne pobornike nestvarnih razmjera stradanja Srba u NDH i u logoru Jasenovac. - Znatnije promjene, ali ne i rješiteljne, u odnosu prema broju žrtava logora Jasenovac nastupile su u Srbiji tek nakon pada s vlasti Slobodana Miloševića i ustvari u MŽG-u nakon odlaska dr. Bulajića iz Muzeja te dolaskom na mjesto „vršioca dužnosti direktora” MŽG-a povjesničara Nenada Đorđevića (2002. do 2013.) i napose kada je u ljeto 2013. v. d. direktora Muzeja postao povjesničar prof. dr. Veljko Đurić Mišina.

Dragan Cvetković, povjesničar MŽG-a, održao je nekoliko izlaganja i objavio niz članaka u kojima, oslanjajući se na pokazatelje poimeničnoga popisa iz 1964., donosi svoje izračune mogućega broja žrtava logora Jasenovac. - U ozračju izrazito nepovoljnom za iznošenje „minimizatorskih” izračuna, u vrijeme dok je direktorom MŽG-a bio dr. Bulajić, zagovornik znatno većih brojeva

\footnotetext{
169 BULAJIĆ, „Različiti podaci o broju stradalih u sistemu logora genocida Jasenovac sa posebnim osvrtom na stradanje Roma”, 18.

170 KOVAČIĆ, „Jasenovac - žrtve rata prema podacima Statističkog zavoda Jugoslavije”, 220-222; MATAUŠIĆ, Jasenovac 1941.-1945., 121-122; GEIGER, „Ljudski gubici Hrvatske u Drugom svjetskom ratu koje su prouzročili 'okupatori i njihovi pomagači'. Brojidbeni pokazatelji”, 723 i GEIGER, „Brojidbeni pokazatelji o žrtvama logora Jasenovac, 1941.-1945., 218.

171 Usp. BOGOSAVLJEVIĆ, „Drugi svetski rat - žrtve u Jugoslaviji”, 11-16; BOGOSAVLJEVIĆ, „Nerasvetljeni genocid”, u: Srpska strana rata (1996.), 159-170 ili BOGOSAVLJEVIĆ, „Nerasvetljeni genocid”, u: Srpska strana rata (2002.), 190-202 i BOGOSAVLJEVIĆ, „Drugi svetski rat žrtve. Jugoslavija", 487-507.

172 KOČOVIĆ, Sahrana jednog mita. Žrtve Drugog svetskog rata u Jugoslaviji.
} 
žrtava logora Jasenovac, Cvetković je počevši od 2000. godine nastojao mogući broj žrtava logora Jasenovac odrediti na temelju pokazatelja poimeničnih popisa. - Riječ je o njegovim izlaganjima „Koncentracioni logor Jasenovac april - novembar 1944. godine” na Drugoj međunarodnoj konferenciji Jasenovac - Sistem hrvatskih ustaških logora genocida (1941-1945) u svibnju 2000. u Banjoj Luci i „Stvarni gubici Hrvatske prema popisu Žrtve rata 1941-1945. iz 1964. godine. Analiza trenutnog stanja prema do sada izvršenoj reviziji" na Dijalogu povjesničara/istoričara u Herceg Novom u ožujku 2001. godine. ${ }^{173} \mathrm{U}$ kasnijim svojim radovima o ljudskim gubicima u NDH i logoru Jasenovac Cvetković je izračune opširnije i detaljnije razradio te prikazao nacionalnu/etničku, dobnu, spolnu, regionalnu i dr. strukturu žrtava. Nezaobilazni su njegovi članci: „Jasenovac u sistemu stradanja civila u NDH - kvantitativna analiza (ili, ponovo o brojevima)" u zborniku radova Četvrte međunarodne konferencije o Jasenovcu, objavljen 2007., „Koncentracijski logor Jasenovac i njegova uloga u uništavanju naroda NDH - izračun mogućeg broja žrtava na temelju djelomično revidiranog popisa iz 1964. godine" u zborniku radova Jasenovac - manipulacije, kontroverze i povijesni revizionizam, objavljen 2018., i „Geostatička analiza ljudskih gubitaka u koncentracionom logoru Jasenovac" u časopisu Istorija 20. veka, objavljen 2019. godine. ${ }^{174}$ - Prema Cvetkovićevim izračunima, tijekom godina neznatno korigiranim, u logoru Jasenovac život je izgubilo najviše Srba 77.011 - 81.950, zatim Roma 18.916 - 20.129 i Židova 17.926 - 19.076 te 6004 - 6389 Hrvata, 1357 - 1444 Muslimana i 1064 - 1132 ostalih i nepoznato, što ukupno iznosi 122.279 - 130.120 osoba. Njegov izračun nacionalne/etničke strukture jasenovačkih žrtava, na temelju revidiranog - djelomično dopunjenog popisa iz 1964., po godinama stradanja prikazan je sažeto u tablici:

173 Usp. CVETKOVIĆ, „Koncentracioni logor Jasenovac april - novembar 1944. godine”, 104108 i 295-306; CVETKOVIĆ, „Stvarni gubici Hrvatske prema popisu Žrtve rata 1941-1945. iz 1964. godine”, 481-501 ili CVETKOVIĆ, „Stvarni gubici Hrvatske 1941.-1945. godine”, 53-98.

174 Usp. CVETKOVIĆ, „Popis ‘Žrtve rata 1941-1945’ iz 1964. godine kao osnova za izračunavanje stradanja stanovništva Jugoslavije”, 77-84; CVETKOVIĆ, „Stradanje civila Nezavisne Države Hrvatske u logoru Jasenovac”, 153-168; CVETKOVIĆ, „Jasenovac u sistemu stradanja civila u NDH - kvantitativna analiza (ili, ponovo o brojevima)”, 69-82; CVETKOVIĆ, „Bosna i Hercegovina - numeričko određivanje ljudskih gubitaka u Drugom svetskom ratu”, 79-156; CVETKOVIĆ, „Stradanje stanovništva NDH u logorima - numeričko određenje”, 41-56; CVETKOVIĆ, „Holokaust u Nezavisnoj Državi Hrvatskoj - numeričko određenje”, 163-182; CVETKOVIĆ, „Koncentracijski logor Jasenovac i njegova uloga u uništavanju naroda NDH - izračun mogućeg broja žrtava na temelju djelomično revidiranog popisa iz 1964. godine”, 171-222 i CVETKOVIĆ, „Geostatička analiza ljudskih gubitaka u koncentracionom logoru Jasenovac”, 93-120. 


\begin{tabular}{|l|l|l|l|l|l|l|}
\hline \multicolumn{6}{|c|}{ Broj i nacionalna/etnička struktura žrtava logora Jasenovac prema izračunu Dragana } \\
\hline & 1941. & 1942. & 1943. & 1944. & 1945. & Ukupno \\
\hline Srbi & $8763-9326$ & $52.822-56.209$ & $4728-5032$ & $7855-8359$ & $2842-3024$ & $77.011-81.950$ \\
\hline Romi & $2291-2438$ & $15-278-16.258$ & $357-380$ & $950-1010$ & $42-44$ & $18.916-20.129$ \\
\hline Židovi & $3798-4042$ & $12.017-12.788$ & $889-946$ & $495-526$ & $726-773$ & $17.926-19.076$ \\
\hline Hrvati & $828-882$ & $1739-1850$ & $519-553$ & $1160-1235$ & $1757-1869$ & $6004-6389$ \\
\hline Muslimani & $149-159$ & $307-326$ & $177-187$ & $394-420$ & $329-350$ & $1357-1444$ \\
\hline $\begin{array}{l}\text { Ostali i } \\
\text { nepoznati }\end{array}$ & $213-226$ & $704-750$ & $78-83$ & $41-44$ & $27-29$ & $1064-1132$ \\
\hline Ukupno & $16.043-$ & $82.868-88.182$ & $6750-7183$ & $\begin{array}{l}10.895- \\
11.594\end{array}$ & $5723-6090$ & $\begin{array}{l}122.279- \\
130.120\end{array}$ \\
\hline
\end{tabular}

Popis ljudskih gubitaka Jugoslavije u Drugome svjetskom ratu iz 1964., osim što nije iskazao gubitke na „neprijateljskoj” strani, manjkav je ponajprije zbog utjecaja greške pamćenja i(li) zaborava (Memory effect), što se moglo i očekivati. Iako taj popis nije ispunio očekivanja, teško je prihvatiti da nije proveden sustavno. ${ }^{175}$ Savezni zavod za statistiku SFR Jugoslavije procijenio je u izvještaju Žrtve rata 1941-1945. godine. (Rezultati popisa), svjestan mogućega broja stvarnih gubitaka, da je popisom trebalo obuhvatiti od 1.016 .000 do 1.066.000 osoba. Sve republičke komisije, osim makedonske, nakon terenske provjere obuhvata popisa, koja je najsustavnije provedena u Socijalističkoj Republici Hrvatskoj, ocijenile su popis uspješnim. Kako radom Komisije za popis žrtava rata SIV-a SFR Jugoslavije iz 1964. nije dobiven za jugoslavenski režim očekivani broj ljudskih gubitaka od 1.706.000, nego znatno manji, u izvještaju Žrtve rata 1941-1945. godine. (Rezultati popisa) i dodatnom „Izveštaju o izvršenom popisu žrtava rata 1941-1945. godine" Savezne komisije za popis žrtava rata 1941-1945. zaključeno je, poprilično neuvjerljivo, uz navođenje svega što je uvjetovalo neuspješnost popisa, da je učinjen niz propusta pri izradi popisnika, da je popis nepotpun i da je popisom obuhvaćeno oko 56 do $59 \%$ ili pak 60 do $65 \%$ osoba, bez objašnjenja na temelju kakva izračuna je takav zaključak moguć. ${ }^{176}$ - Tu je i ključno pitanje ili „ozbiljan problem”, kako je to nazvao dr. Željko Krušelj, metodologije izračuna broja žrtava logora Jasenovac na temelju popisa iz 1964. i neuvjerljivoga objašnjenja o (ne)uspješnosti toga popisa i izra-

175 Usp. GEIGER, „Ljudski gubici Hrvatske u Drugom svjetskom ratu koje su prouzročili okupatori i njihovi pomagači'. Brojidbeni pokazatelji”, 708 i GEIGER, „Brojidbeni pokazatelji o žrtvama logora Jasenovac, 1941.-1945.", 218 i ondje navedena literatura.

176 Usp. Žrtve rata 1941-1945. godine. (Rezultati popisa), 5-7 i dodatni „Izveštaj o izvršenom popisu žrtava rata 1941-1945.“, VII-XV. 
zito velikom postotku nepopisanih, što upućuje na „tadašnju političku potrebu očuvanja unaprijed zadanih brojki”. ${ }^{177}$

Istovremeno je i povjesničar MŽG-a Jovan Mirković, ponajbolji poznavatelj mnogobrojne i gotovo nesagledive literature o logoru Jasenovac, odustao od svojega prijašnjega dugogodišnjeg određivanja da je u Jasenovcu život izgubilo „nekoliko stotina hiljada” osoba ${ }^{178}$ jer u „Predgovoru” dvojezičnoga izdanja, na hrvatskom i engleskom jeziku, izvještaja Zemaljske komisije Hrvatske za utvrđivanje zločina okupatora i njihovih pomagača o logoru Jasenovac iz 1946., objavljenog 2000., takav njegov eksplicitni navod ne nalazimo. ${ }^{179}$ Mirković, koji je i dalje zastupao tezu o genocidu nad Srbima u NDH i o protusrpskoj usmjerenosti Katoličke crkve, ne određuje se o broju žrtava logora Jasenovac ni u svojim kasnijim radovima i spominje različite navode, tvrdnje i izračune i procjene te i poimenične popise, iako očito ne otklanja mogućnost i većega broja jasenovačkih žrtava negoli je utvrđeno i moguće utvrditi poimenično, a i izračunima/procjenama. ${ }^{180}$ - Rezultati revizije - dopune poimeničnoga popisa žrtava logora Jasenovac utvrđeni u MŽG-u i Cvetkovićevi izračuni broja i strukture jasenovačkih žrtava, pa i Mirkovićeva pisanja u kojima se uglavnom držao tih pokazatelja, naišli su na nepodijeljeno odobravanje izvan nacionalističkih krugova u Hrvatskoj, i među povjesničarima lijevoga usmjerenja, jer su ti pokazatelji i poimeničnoga popisa i izračuna „podržavali” broj žrtava logora Jasenovac od oko 100.000, koji su oni bez zadrške prihvatili kao vjerodostojan. ${ }^{181}$

Da bi priča o „minimiziranju” jasenovačkih žrtava u Srbiji bila zanimljivija, direktor MŽG-a, povjesničar Đurić Mišina, otprije je bio poznat kao zastupnik teze o protusrpskoj usmjerenosti Katoličke crkve i genocidnosti hrvatske politike prema Srbima, u čemu je dosljedan i danas, ali je zdravorazumski odustao od nemogućih stotina tisuća, 700.000 ili više žrtava logora Jasenovac,

\footnotetext{
177 KRUŠELJ, Zarobljenici paralelnih povijesti, 64.

178 MIRKOVIĆ, Objavljeni izvori i literatura o jasenovačkim logorima, 7.

179 Usp. MIRKOVIĆ, „Predgovor”/„Forward”, V-XXIX/5-31.

180 Usp. primjerice: MIRKOVIĆ, „Izdanja Muzeja žrtava genocida i građa o ljudskim gubicima u tim izdanjima”, 573-591; MIRKOVIĆ, „Građa o jasenovačkom logoru”, 23-37; MIRKOVIĆ, „Hronologija zločina (april - avgust 1941. godine) - prilog dokazima o genocidnom karakteru Nezavisne Države Hrvatske”, 11-78; MIRKOVIĆ, „Žrtve rata 1941-1945. sa područja Bosanske krajine - prilog istraživanju genocida”, 11-52; MIRKOVIĆ, Zločini nad Srbima u Nezavisnoj Državi Hrvatskoj = Crimes against the Serbs in the Independent state of Croatia i MIRKOVIĆ, „Poimenična identifikacija - prilog metodologiji utvrđivanja broja žrtava genocida i ratnih zločina (na primeru NDH)", 57-69.

181 Usp. MATAUŠIĆ, Jasenovac 1941.-1945., 122; I. GOLDSTEIN, „O broju jasenovačkih i blajburških žrtava”, 312; I. GOLDSTEIN, „O broju žrtava jasenovačkog logorskog kompleksa”, 122 123; I. GOLDSTEIN, Jasenovac (2018.), 781-782, 790 ili I. GOLDSTEIN, Jasenovac (2019.), 781782, 790; KRUŠELJ, Zarobljenici paralelnih povijesti, 64-67.
} 
uglavnom Srba. ${ }^{182}$ Iako mu se ne može zanijekati stručnost, a i srpski nacionalizam, na mjestu direktora MŽG-a brzo se ekstremnim srpskim nacionalistima zamjerio „minimiziranjem” žrtava logora Jasenovac. - No istovremeno je Đurić Mišina napadan u hrvatskom nacionalističkom tisku zbog „uvećavanja” broja žrtava u NDH, napose srpskih. - Tako je, primjerice, u Hrvatskom tjedniku u studenom 2017. obznanjeno: „Voditelj Muzeja žrtava u Beogradu je Veljko Đurić Mišina, rodom iz okolice Vrlike, strateg je uvećavanja i izmišljanja srpskih žrtava."183 Pozivanjem na netočne podatke objavljene u hrvatskom tisku (Slobodna Dalmacija) ${ }^{184}$ prozvan je i MŽG, odnosno Dragan Cvetković, jer je navodno na znanstvenom skupu u Zagrebu iznio da je u logorima u NDH stradalo „između 504 tisuće i 536 tisuća civila svih nacionalnosti i vjera, od čega je između 325 i 345 tisuća Srba” ${ }^{185}$ Usto, na Okruglom stolu Odgovornost države Hrvatske za izvršeni genocid nad srpskim narodom i drugim narodima u periodu 1941-1945. i 1991-1995. godine, održanom u Beogradu početkom ožujka 2007., na kojem su se okupili najistaknutiji srpski zastupnici teze o 700.000 ili barem najmanje nekoliko stotina tisuća žrtava logora Jasenovac, uglavnom Srba, dr. Bulajić prozvao je Cvetkovića da je surađivao s Hrvatima bez njegove suglasnosti kao direktora Muzeja. ${ }^{186}$ - Teško je reći što je gore za Srbina iz Jagodine, „minimiziranje” srpskih žrtava u NDH i logoru Jasenovac ili suradnja s Hrvatima. - Dakle, ista nastojanja za jedne su „minimiziranje”, a za druge „uvećavanje”. - No sviđalo se to nekome ili ne, zasluga je ponajprije Cvetkovića, a i Mirkovića te i MŽG-a, odnosno direktora Đorđevića i napose Đurića Mišine, da je učinjen znatan odmak od „sakrosanktnoga” broja jasenovačkih žrtava.

Stajališta Đurića Mišine, koji je potkraj 2018. na mrežnim stranicama MŽG-a o broju žrtava logora Jasenovac objavio i napis „Nije sto hiljada malo"187 i zatim godinu poslije iznio mišljenje o „doprinosu” prof. dr. Gideona Greifa istraživanju logora Jasenovac, potvrdila su stajališta srpskih zastupnika

\footnotetext{
${ }_{182}$ Usp. primjerice: Velj. ĐURIĆ, Ustaše i pravoslavlje i Velj. ĐURIĆ, Prekrštavanje Srba u Nezavisnoj Državi Hrvatskoj.

183 Usp. KOZLICA, „Muzej genocida iz Beograda - krivotvorenim podatcima do većeg broja žrtava Drugoga svjetskog rata”, 42.

184 Usp. PSD, „Najnovije istraživanje Muzeja žrtava genocida iz Beograda” i „Demantirane “napuhane' brojke. U NDH je ubijeno oko pola milijuna logoraša”.

185 Usp. KOZLICA, „Muzej genocida iz Beograda - krivotvorenim podatcima do većeg broja žrtava Drugoga svjetskog rata”, 42. Da je riječ o netočnim navodima u Slobodnoj Dalmaciji i Hrvatskom tjedniku, usp. CVETKOVIĆ, „Stradanje stanovništva NDH u logorima - numeričko određenje".

186 Usp. BULAJIĆ, „Različiti podaci o broju stradalih u sistemu logora genocida Jasenovac sa posebnim osvrtom na stradanje Roma”, 38-39.

187 „Nije sto hiljada malo”. Riječ je o uvodniku prvotno objavljenom u Prosvjeti br. 144 (septembar 2018.), novinama za kulturu Srpskog kulturnog društva Prosvjeta, Zagreb. Usp. (B.), „Nije sto hiljada malo".
} 
teze o stotinama tisuća, 700.000 i više žrtava logora Jasenovac o protusrpskoj djelatnosti MŽG-a. - Potkraj 2019. na muzejskim mrežnim stranicama Đurić Mišina objavio je i izrazito negativan osvrt na Greifovu knjigu Jasenovac Auschwitz of the Balkans i naglasio da ta knjiga „nije istoriografska studija o Jasenovcu, već propagandistička kompilacija”. ${ }^{188}$ - Nije zanemarivo, radi se o prvom ozbiljnijem osvrtu na Greifovu knjigu nekoga srpskog povjesničara. - Tada su verbalni napadi ekstremnih srpskih nacionalista na MŽG i direktora Muzeja Đurića Mišinu uzeli maha. Političkim pritiscima na Ministarstvo kulture i informisanja Republike Srbije pokušalo se i ukloniti Đurića Mišinu s mjesta direktora MŽG-a. Kao razlog za smjenu izneseno je „umanjivanje broja žrtava u sistemu koncentracionih logora Jasenovac, koje u poslednje vreme propagira grupa istoričara iz tog muzeja i predsednik Upravnog odbora Muzeja žrtava genocida, vladika Jovan Ćulibrk, ujedno i predsednik Odbora za Jasenovac SAS SPC [Svetog arhijerejskog sabora Srpske pravoslavne crkve]” ${ }^{189}$ - Bio bi ponekad i red poslušati „istinoljubive” srpske nacionaliste i smijeniti direktora MŽG-a Đurića Mišinu, koji je prema mišljenju njihovih antipoda u Hrvatskoj „strateg uvećavanja i izmišljanja srpskih žrtava” u NDH i logoru Jasenovac, a i predsjednika Upravnoga odbora MŽG-a vladiku Ćulibrka, jer je i on omiljena meta napada i hrvatskih nacionalista. ${ }^{190}$

Iskazi i sjećanja logoraša Jasenovca o broju ubijenih jasenovačkih zatočenika različiti su i u preširokom rasponu broja žrtava i za pojedine slučajeve i za određena razdoblja, i nedvojbeno su izrečeni odoka te krajnje nepouzdani. - Ali Dušan Nikodijević objavio je 2016. - 2019. u Godišnjaku za istraživanje genocida nekoliko članaka ${ }^{191}$, a zatim 2019. i knjigu Jasenovac između broja $i$ žrtve. Prilog proučavanju broja žrtava u sistemu koncentracionog logora Jasenovac. ${ }^{192} \mathrm{Na}$ temelju iskaza i sjećanja zatočenika povjesničar Nikodijević izračunava da je broj žrtava logora Jasenovac i Stara Gradiška 1941. - 1945. minimalno 99.370 i maksimalno 208.346. Po logorima i godinama sumarni rezultati Nikodijevićeva izračuna žrtava logora Jasenovac i Stara Gradiška prikazani su u tablici:

\footnotetext{
188 Usp. ĐURIĆ MIŠINA, „Gideon Grajf, Jasenovac Aušvic Balkana, Beograd 2018, 712 strana”.

189 Usp. „Smena direktora Muzeja žrtava genocida” i „Da li je u toku smena direktora Muzeja žrtava genocida?".

190 Usp. „Srpski svećenik Ćulibrk i Židov Zuroff žele pripisati srpska ubojstva Židova Paveliću!” i VUKOVIĆ, „Otvoreno pismo episkopu, gospodinu Jovanu Ćulibrku”, 20-23.

191 Usp. NIKODIJEVIĆ, „Prilog utvrđivanju broja žrtava sistema logora Jasenovac 1941. godine”, 169-213; NIKODIJEVIĆ, „Brojevi žrtava u koncentracionom logoru Jasenovac 1942. godine prema iskazima preživelih svedoka”, 95-117; NIKODIJEVIĆ, „Brojevi žrtava u koncentracionom logoru Stara Gradiška 1942. godine prema iskazima preživelih svedoka”, 127-155 i NIKODIJEVIĆ, „Brojevi žrtava u sistemu koncentracionog logora Jasenovac 1943-1945. godine prema iskazima preživelih svedoka", 137-172.

192 Usp. NIKODIJEVIĆ, Jasenovac između broja i žrtve.
} 


\begin{tabular}{|l|c|c|}
\hline \multicolumn{3}{|c|}{ Broj žrtava logora Jasenovac i Stara Gradiška prema izračunu Dušana Nikodijevića } \\
\hline Logor & Godina & Broj žrtava \\
\hline Krapje i Bročice & 1941. & $2168-10.031$ \\
\hline Ciglana & 1941. & $5207-5962$ \\
\hline Ciglana i Kožara & 1942. & $53.751-12.308$ \\
\hline Ciglana i Kožara & $1943 .-1945$. & $16.762-42.548$ \\
\hline Stara Gradiška & 1942. & $16.496-29.900$ \\
\hline Stara Gradiška & $1943 .-1945$. & $4986-7597$ \\
\hline Ukupno & $1941 .-1945$. & $99.370-208.346$ \\
\hline
\end{tabular}

Nedvojbeno su iskazi i sjećanja neprocjenjivi kad je riječ o pojedinim slučajevima ili u opisu ozračja. Iskazi i sjećanja o logorima Jasenovac i Stara Gradiška izneseni su u različitim prigodama i nabijeni emocijama i traumama te su nepouzdani kad se radi o brojevima. Upitne su vrijednosti ponajprije veći brojčani navodi jer su izrečeni odoka. Određivanju broja umrlih i ubijenih ljudi u logoru Jasenovac ne može se pristupati na temelju iskaza i sjećanja, pa makar ona bila i jedini izvor za neko razdoblje, nego na temelju stvarnih pokazatelja, ponajprije dokumenata i poimeničnih popisa, da bi se došlo do najpribližnijih podataka o broju žrtava. To što su iskazi i sjećanja najčešće jedini izvor ništa ne znači niti rješava, a ono što nije provjerljivo - upitno je. Jer brojevi žrtava prema iskazima i sjećanjima najčešće su, ako ne redovito, pretjerani, pa i višestruko pretjerani. S takvim brojkama trebalo bi postupati krajnje oprezno jer ono što spominju iskazi i sjećanja najčešće ne odgovara stvarnosti. Ukratko, metodologija dobivanja broja logorskih žrtava izračunom na temelju iskaza i sjećanja je dvojbena. Iskazi i sjećanja krajnje su nepouzdani jer su mnogi navodili ono što su mislili da je bilo, ili čak ono što se od njih očekivalo. Tko je od svjedoka i koliko njih osobno bilo ondje, vidjelo i brojilo, ili se radi o brojevima odoka kako je netko izrekao, drugi čuo, ili izmislio. Da je moguće na temelju iskaza i sjećanja zatočenika iole valjano riješiti broj žrtava nekoga logora, to bi nesumnjivo netko i prije učinio.

Može se steći dojam da „umjereniji” srpski povjesničari u osporavanju u srpskoj javnosti, publicistici, ali i historiografiji sveprisutnih nemogućih brojeva jasenovačkih žrtava nastoje u posljednje vrijeme taj broj stabilizirati na minimalno nešto više od 100 tisuća. - Ne tako davno, zastupati u Srbiji brojeve koji doprinose „minimiziranju zločina genocida” nije bilo najuputnije. - Primjerice, od istaknutijih srpskih povjesničara mlađe generacije među prvima je dr. Kosta Nikolić (Institut za savremenu istoriju, Beograd), kojega „profesionalni antifašisti” u Srbiji - koji su istovremeno zazirali od MŽG-a i „mudro” se po pitanju broja jasenovačkih žrtava držali postrani - nepodijeljeno svrsta- 
vaju u Ravnogorce, ustvrdio u travnju 2006., uvažavajući pisanja Bogoljuba Kočovića i Dragana Cvetkovića, da je „Ukupan broj srpskih žrtava na celoj teritoriji Kraljevine Jugoslavije u Drugom svetskom ratu [je] oko 530.000. Na Jasenovac otpada otprilike, od 110 do 125 hiljada ljudi... Između 80 i 90 posto su bili Srbi..."193 Razumljivo, dr. Bulajić je zbog takvih „revizionističkih” navoda Nikolića javno prozvao na Okruglom stolu Odgovornost države Hrvatske za izvršeni genocid nad srpskim narodom i drugim narodima u periodu 1941-1945. i 1991-1995. godine. ${ }^{194}$ - Istovremeno je većina srpskih povjesničara „u zavjetrini” i dalje podržavala, a mnogi zastupaju i danas, stare jugokomunističke, uspješno posrbljene, „megalomanske” navode o razmjerima ustaških zločina u NDH i broju žrtava logora Jasenovac, napose Srba.

Uobičajeno je, i u Srbiji i u Hrvatskoj, pa i šire u „regionu”, da promjene politički zadanih činjenica najteže ulaze u udžbenike povijesti. U Srbiji su prve promjene počele tek prije desetak godina. Među malobrojnim srpskim povjesničarima, autorima školskih udžbenika povijesti, koji su se udaljili od uporno promicanih mitskih brojki o jasenovačkim žrtvama od nekoliko stotina tisuća i najčešće 700.000 bili su prof. dr. Đorđe Đurić (Odsek za istoriju Filozofskoga fakulteta u Novom Sadu) i prof. dr. Momčilo Pavlović (Institut za savremenu istoriju, Beograd), koji spominju koliko je do tada poimenično „evidentiranih” žrtava logora Jasenovac. ${ }^{195}$

Zamjetno je da odmak od uporno promicanih „megalomanskih” brojeva žrtava u NDH i logora Jasenovac danas znatnim dijelom prihvaćaju povjesničari Instituta za savremenu istoriju i Instituta za noviju istoriju Srbije, u čijim je časopisima Istorija 20. veka i Tokovi istorije povjesničar MŽG-a Cvetković objavio nekoliko zapaženih članaka. - Uporištima starih „megalomanskih” navoda o ustaškim zločinima u NDH i broju žrtava logora Jasenovac, napose Srba, ostale su Srpska akademija nauka i umetnosti i Srpska pravoslavna crkva, uz odobravanje pojedinaca i skupina na Odeljenju za istoriju Filozofskoga fakulteta u Beogradu i Odseku za istoriju Filozofskoga fakulteta u Novom Sadu, koji ponosno inkliniraju desno. - No među „minimizatore” broja žrtava logora Jasenovac uvrstili su se posljednjih godina i notorni srpski nacionalisti. Prof. dr. Srđa Trifković (Fakultet političkih nauka Univerziteta u Banjoj Luci) u članku „Ustaša crimes, Serbian victims, numbers and politics: toward a rational debate", objavljenom 2020. u časopisu Istorija 20. veka, priklanja se Cvetkovićevu izračunu od oko 130.000 žrtava logora Jasenovac, od čega je dvi-

193 Usp. „Da li je u Jasenovcu izvršen genocid nad Srbima?”.

194 Usp. BULAJIĆ, „Različiti podaci o broju stradalih u sistemu logora genocida Jasenovac sa posebnim osvrtom na stradanje Roma”, 39.

195 Usp. ĐURIĆ, PAVLOVIĆ, Istorija za osmi razred osnovne škole, 153 i ĐURIĆ, PAVLOVIĆ, Istorija za treći razred gimnazije prirodno-matematičkog smera i četvrti razred gimnazije opšteg $i$ društveno-jezičkog smera, 206. 
je trećine Srba. ${ }^{196}$ Trifković je uz Đurića Mišinu među malobrojnim srpskim povjesničarima koji otvoreno osporavaju pisanja prof. dr. Greifa o Jasenovcu. („A paradigmatic example is provided by the pseudoscientific compilation of poorly edited material by a self-styled 'Auschwitz expert' (as we are eccentrically told from the cover of his book), Gideon Greif. [...] He offers no evidence to support such claims, which are utterly devoid of rational grounding. $\mathrm{He}$ even claims support for his assertions from an unnamed 'international group of experts', of unknown origin or composition. Not a single new document, not a single original idea, is contained in Greif's work. Predictably, not a single refereed journal has reviewed his work, and rightly so. It is 'fake history' par excellence. [...]") $)^{197}$ - Mali je to iskorak za historiografiju, ali veliki za prof. dr. Trifkovića, autora knjige Ustaše: Balkansko srce tame i slikovitih opisa i razmjera srpskih žrtava u NDH i logora Jasenovac koje je prije godinama uporno zastupao i promicao. ${ }^{198}$

Nakon svega, „minimizatori” broja žrtava logora Jasenovac u Srbiji i danas su u manjini, i u javnosti i medijima „nadglasani”, jer se mnogi, i povjesničari, i dalje priklanjaju dostatnim i samoobnovljivim izvorima izmišljotina i gluposti koji „dokazuju” znatno veće, „istinoljubivoj javnosti” i vladajućoj politici i u Republici Srbiji i Republici Srpskoj prihvatljive brojke jasenovačkih žrtava od milijun, 700.000 ili barem nekoliko stotina tisuća. - No „istinoljubivim” Srbima, a i srpskim i hrvatskim „,antifašistima”, za malu utjehu: i kod većine srpskih „revizionista” i „minimizatora” broja žrtava ustaških zločina u NDH i logora Jasenovac narativ o ustaškim zločinima i jasenovačkom logoru ostao je isti. U mnogočemu s pravom.

\section{Izvori i literatura}

AKMADŽA, Miroslav; JAREB, Mario; RADELIĆ, Zdenko. Povijest 4. Udžbenik za 4. razred gimnazije. Zagreb: Alfa, 2009.

ALMULI, Jaša. Jevreji i Srbi u Jasenovcu. Beograd: Službeni glasnik, 2009.

(B.). „Nije sto hiljada malo”. Prosvjeta. Novine za kulturu, Srpsko kulturno društvo Prosvjeta, br. 144 (Zagreb, septembar 2018.). Pristup ostvaren 27. 3. 2020. http://casopis.skd-prosvjeta.hr/wp-content/uploads/2018/09/144-Prosvjeta-za-web-1.pdf.

\footnotetext{
196 Usp. TRIFKOVIĆ, „Ustaša crimes, Serbian victims, numbers and politics: toward a rational debate", 203-222.

198 Usp. TRIFKOVIĆ, Ustaše: Balkansko srce tame na evropskoj političkoj sceni. Prvotno objavljeno na engleskom jeziku 1998. u Londonu, The Lord Byron foundation for Balkan studies, pod naslovom Ustaša: Croatian separatism and European politics, 1929-1945, a zatim 2011. pod naslovom Croatian Fascism and European Politics, 1929-1945.
} 
BANIĆ, Nikola; KOIĆ, M.[laden]. „Jasenovački mit u 'dobrom' društvu Kominterne. Jasenovački je popis žrtava MASOVNA PRIJEVARA koju održavaju propagandni manipulatori”. Hrvatski tjednik (Zadar), br. 813, 23. 4. 2020., 17-19.

BARBARIĆ, Ilija. Nezavisna Država Hrvatska bilo je pravo ime. Split: Naklada Bošković, 2010.

BARBIĆ, Anđelko. „Prilozi problematici istraživanja broja žrtava u KCL Jasenovac od 1941. do 1945.” Slavonski povijesni zbornik 25 (1988), br. 1-2: 8197.

BEKAVAC, Stjepan; JAREB, Mario. Povijest 8. Udžbenik za osmi razred osnovne škole. Zagreb: Alfa, 2017.

BOGOSAVLJEVIĆ, Srđan. „Drugi svetski rat - žrtve. Jugoslavija”. U: Dijalog povjesničara/istoričara, sv. 4, prir. Hans-Georg Fleck i Igor Graovac. Zagreb: Friedrich Naumann Stiftung, 2001, 487-507.

BOGOSAVLJEVIĆ, Srđan. „Drugi svetski rat - žrtve u Jugoslaviji”. Republika (Beograd), br. 117, 1.-15. 7. 1995., 11-16.

BOGOSAVLJEVIĆ, Srđan. „Nerasvetljeni genocid”. U: Srpska strana rata. Trauma i katarza u istorijskom pamćenju, prir. Nebojša Popov. Zrenjanin: Republika, 1996, 159-170.

BOGOSAVLJEVIĆ, Srđan. „Nerasvetljeni genocid”. U: Srpska strana rata. Trauma i katarza u istorijskom pamćenju, I deo, prir. Nebojša Popov. Beograd: Samizdat B92, 2002, 190-202.

BULAJIĆ, Milan. Jasenovac. Balkan Auschwitz. System of Croatian Nazi-Ustasha Genocide Camps for Serbs, Jews and Gypsies. Belgrade: Museum of Genocide Victims; Stručna knjiga, 2001.

BULAJIĆ, Milan. Jasenovac. Ustaški logor smrti. „Srpski mit?”. Hrvatski ustaški logori genocida nad Srbima, Jevrejima i Ciganima. Beograd: Muzej žrtava genocida; Stručna knjiga, 1999.

BULAJIĆ, Milan. Jasenovac na sudu. Suđenje D. Šakiću (Jasenovac-sistem ustaških logora genocida, balkanski Aušvic). Beograd: Muzej žrtava genocida; Stručna knjiga, 2001.

BULAJIĆ, Milan. „Jasenovački mit” Franje Tuđmana - Genocid nad Srbima, Jevrejima i Ciganima. Beograd: Stručna knjiga, ${ }^{1} 1994,{ }^{2} 1997$.

BULAJIĆ, Milan. Misija Vatikana u Nezavisnoj Državi Hrvatskoj. "Politika Stepinac" razbijanja jugoslovenske države i pokatoličavanja pravoslavnih Srba po cijenu genocida; stvaranje Civitas Dei - Antemurale Christiantitais, I-II. Beograd: Politika, 1992. 
BULAJIĆ, Milan. „Politika genocida nad Srbima kroz sistem logora Jasenovac". U: Zatiranje Srba u Hrvatskoj, prir. Bogdan Zlatar. Beograd: IKP Nikola Pašić, 2008, 213-233.

BULAJIĆ, Milan. „Različiti podaci o broju stradalih u sistemu logora genocida Jasenovac sa posebnim osvrtom na stradanje Roma”. U: Odgovornost države Hrvatske za izvršeni genocid nad srpskim narodom $i$ drugim narodima u periodu 1941-1945. i 1991-1995. godine (Okrugli sto - Beograd, 9. Marta 2007.), ur. Smilja Tišma. Beograd: Udruženja zatočenika i potomaka zatočenika logora genocida u Nezavisnoj Državi Hrvatskoj 1941-1945.; Pešić i sinovi, 2007, 34-44.

BULAJIĆ, Milan. The Independent State of Croatia, Jasenovac, The system of Ustasha death Camps. Tudjman's „Jasenovac Myth”. Belgrade: Stručna knjiga, 1996.

BULAJIĆ, Milan. Tudjman's „Jasenovac Myth”. Genocide against Serbs, Jews and Gypsies. Beograd: Stručna knjiga, 1994.

BULAJIĆ, Milan. Tudjman's „Jasenovac Myth”. Ustasha crimes of Genocide. Belgrade: The Ministry of information of The Republic of Serbia, 1992.

BULAJIĆ, Milan. Ustaški zločini genocida i suđenje Andriji Artukoviću 1986. godine, knj. I-IV. Beograd: Rad, 1988-1989.

BULATOVIĆ, Radomir. Koncentracioni logor Jasenovac, s posebnim osvrtom na Donju Gradinu. Istorijsko-sociološka i antropološka studija. Sarajevo: Svjetlost, 1990.

CVETKOVIĆ, Dragan. „Bosna i Hercegovina - numeričko određivanje ljudskih gubitaka u Drugom svetskom ratu”. U: Prilozi istraživanju zločina genocida i ratnih zločina. Zbornik radova, ur. Jovan Mirković. Beograd: Muzej žrtava genocida, 2009, 79-156.

CVETKOVIĆ, Dragan. „Geostatička analiza ljudskih gubitaka u koncentracionom logoru Jasenovac”. Istorija 20. veka 37 (2019), br. 1: 93-120.

CVETKOVIĆ, Dragan. „Holokaust u Nezavisnoj Državi Hrvatskoj - numeričko određenje”. Istorija 20. veka 29 (2011), br. 1: 163-182.

CVETKOVIĆ, Dragan. „Jasenovac u sistemu stradanja civila u NDH kvantitativna analiza (ili, ponovo o brojevima)". U: Jasenovac. Zbornik radova Četvrte međunarodne konferencije o Jasenovcu, ur. Zdravko Antonić i Janko Velimirović. Kozarska Dubica; Banja Luka: Javna ustanova Spomen-područja Donja Gradina; Udruženje Jasenovac - Donja Gradina, 2007, 69-82.

CVETKOVIĆ, Dragan. „Koncentracijski logor Jasenovac i njegova uloga u uništavanju naroda NDH - izračun mogućeg broja žrtava na temelju djelomično revidiranog popisa iz 1964. godine”. U: Jasenovac - manipulacije, kon- 
troverze i povijesni revizionizam. Zbornik radova, ur. Andriana Benčić, Stipe Odak i Danijela Lucić. Jasenovac: Javna ustanova Spomen područje Jasenovac, 2018, 171-222.

CVETKOVIĆ, Dragan. „Koncentracioni logor Jasenovac april - novembar 1944. godine". U: Druga međunarodna konferencija Jasenovac - Sistem hrvatskih ustaških logora genocida (1941-1945), 8-10. maj 2000. godine, Banja Luka - Donja Gradina, gl. ur. Žana Ateljević. Banja Luka: Sekretarijat Druge međunarodne konferencije „Jasenovac - Sistem hrvatskih ustaških logora genocida (1941-1945)"; Dokumentacioni centar Republike Srpske za istraživanje ratnih zločina, 2002, 104-108 i 295-306.

CVETKOVIĆ, Dragan. „Popis ‘Žrtve rata 1941-1945’ iz 1964. godine kao osnova za izračunavanje stradanja stanovništva Jugoslavije. (Neki pokazatelji stradanja srpskog stanovništva)". U: Genocid u 20. veku na prostorima jugoslovenskih zemalja. Zbornik radova, ur. Jovan Mirković. Beograd: Muzej žrtava genocida; Institut za noviju istoriju, 2005, 77-84.

CVETKOVIĆ, Dragan. „Stradanje civila Nezavisne Države Hrvatske u logoru Jasenovac". Tokovi istorije (2007), br. 4: 153-168.

CVETKOVIĆ, Dragan. „Stradanje stanovništva NDH u logorima - numeričko određenje". U: Logori, zatvori i prisilni rad u Hrvatskoj/Jugoslaviji 1941.-1945. / 1945.-1951. Zbornik radova, ur. Vladimir Geiger, Martina Grahek Ravančić i Marica Karakaš Obradov. Zagreb: Hrvatski institut za povijest, 2010, 41-56.

CVETKOVIĆ, Dragan. „Stvarni gubici Hrvatske prema popisu Žrtve rata 1941-1945. iz 1964. godine. Analiza trenutnog stanja prema do sada izvršenoj reviziji”. U: Dijalog povjesničara/istoričara, sv. 5, prir. Hans-Georg Fleck i Igor Graovac. Zagreb: Friedrich Naumann Stiftung, 2002, 481-501.

CVETKOVIĆ, Dragan. „Stvarni gubici Hrvatske 1941.-1945. godine”. U: Igor Graovac, Dragan Cvetković, Ljudski gubici Hrvatske 1941.-1945. godine: pitanja, primjeri, rezultati... Zagreb: Zajednica izdavača Dijalog, Udruga za promicanje znanstvenog dijaloga; Zaklada Friedrich Naumann, 2005, 53-98.

ĆULIBRK, Jovan. Istoriografija holokausta u Jugoslaviji. Beograd: Institut za teološka istraživanja, Pravoslavni bogoslovski fakultet Univerziteta u Beogradu; Fakultet bezbednosti, Univerzitet u Beogradu, 2011.

„Da li je u Jasenovcu izvršen genocid nad Srbima?”. Radio Slobodna Evropa, Most, 16. 4. 2006. Pristup ostvaren 27. 3. 2020. https://www.slobodnaevropa.org/a/666218.html.

„Da li je u toku smena direktora Muzeja žrtava genocida?”. Portal Novi Standard, 14. 11. 2019. Pristup ostvaren 27. 3. 2020. https://www.standard. rs/2019/11/14/da-li-je-u-toku-smena-direktora-muzeja-zrtava-genocida/. 
DAKINA, Gojo Riste. Genocid nad Srbima u Nezavisnoj Državi Hrvatskoj: Budi katolik ili umri. Beograd: Institut za savremenu istoriju, 1995.

DEDIJER, Vladimir. Vatikan i Jasenovac. Dokumenti. Beograd: Izdavačka radna organizacija „Rad”, 1987.

Deklaracija o genocidu Nezavisne Države Hrvatske nad Srbima, Jevrejima i Romima tokom Drugog svjetskog rata. Peta medunarodna konferencija o Jasenovcu, 24-25. maj 2011. Banja Luka = Declaration on the genocide committed against the Serbs, Jews and Roma by the Independent State of Croatia during the Second World War. The Fifth International Conference on Jasenovac, May 2425, 2011 Banja Luka, glavni urednici = editors in chief Kosta Čavoški, Smilja Avramov i Vasilije Krestić. Banja Luka: Udruženje Jasenovac - Donja Gradina, 2011.

„Demantirane 'napuhane' brojke. U NDH je ubijeno oko pola milijuna logoraša”. Tportal, 14. 5. 2009. Pristup ostvaren 27. 3. 2020. https://www.tportal.hr/vijesti/clanak/u-ndh-je-ubijeno-oko-pola-milijuna-logorasa-20090514.

DEVERIĆ, Mišo; FUMIĆ, Ivan. Hrvatska u logorima 1941.-1945. Zagreb: Savez antifašističkih boraca i antifašista Republike Hrvatske, 2008.

DIMITRIJEVIĆ, Vladimir. „Jovan Pejin: Jasenovac u srpskoj istoriji”. Udruženje građana „Jadovno 1941.”, 27. 12. 2019. Pristup ostvaren 27. 3. 2020. https://jadovno.com/jovan-pejin-jasenovac-u-srpskoj-istoriji/?lng=lat\#.Xn5RbYhKiM8.

Druga medunarodna konferencija Holokaust nad Srbima, Jevrejima i Romima u Drugom svetskom ratu. Zbornik radova = Second International Conference Holokaust over the Serbs, Jews and Roma during the Second World War. Proceedings, ur. Vojislav Vučenović, Vjačeslav Solovjov, Edit Der Šeregelj i Željko Simić. Beograd: Fakultet za poslovne studije i pravo i Fakultet za strateški i operativni menadžment, Univerzitet „Union - Nikola Tesla”, 2015.

Druga međunarodna konferencija Jasenovac - Sistem hrvatskih ustaških logora genocida (1941-1945), 8-10. maj 2000. godine, Banja Luka - Donja Gradina, gl. ur. Žana Ateljević. Banja Luka: Sekretarijat Druge međunarodne konferencije "Jasenovac - Sistem hrvatskih ustaških logora genocida (1941-1945)"; Dokumentacioni centar Republike Srpske za istraživanje ratnih zločina, 2002.

ĐORĐEVIĆ, Životije. Gubici stanovništva Jugoslavije u Drugom svetskom ratu. Beograd: ABC-Grafika, 1997.

ĐORĐEVIĆ, Životije. Satiranje srpstva u 19. i 20. veku, I-III. Beograd: Draslar partner, 2012.

ĐURIĆ, Đorđe; PAVLOVIĆ, Momčilo. Istorija za osmi razred osnovne škole. Beograd: Zavod za udžbenike, 2010. 
ĐURIĆ, Đorđe; PAVLOVIĆ, Momčilo. Istorija za treći razred gimnazije prirodno-matematičkog smera i četvrti razred gimnazije opšteg i društveno-jezičkog smera. Beograd: Zavod za udžbenike, 2010.

ĐURIĆ, Veljko Đ. Prekrštavanje Srba u Nezavisnoj Državi Hrvatskoj. Prilozi za istoriju verskog genocida. Beograd: „Alfa” Zemun, 1991.

ĐURIĆ, Veljko Đ. Ustaše i pravoslavlje. Hrvatska pravoslavna crkva. Beograd: Beletra, 1989.

ĐURIĆ MIŠINA, Veljko. „Gideon Grajf, Jasenovac Aušvic Balkana, Beograd 2018, 712 strana”. Muzej žrtava genocida. Pristup ostvaren 27. 3. 2020. http://arhiva.muzejgenocida.rs/images/Gideon-grajf-Jasenovac-Ausvic-Balkana.pdf.

ĐURIĆ, Vesna. Povijest 8. Udžbenik za osmi razred osnovne škole. Zagreb: Profil, 2007.

ĐURIĆ, Vesna. Vremeplov 8. Udžbenik povijesti za osmi razred osnovne škole. Zagreb: Profil, 2014.

„Ekskluzivni intervju. Mr. sc. Blanka Matković, predsjednica Hrvatske družbe povjesničara Dr. Rudolf Horvat. Svoju povijest pisat ćemo mi. Nemamo se čega sramiti, ni NDH, ni Jasenovca, odbacimo povijest koju je pisala Partija nakon 1945.” [razgovarao: Ivica Marijačić]. Hrvatski tjednik (Zadar), br. 642, 12. 1. 2017., 37-49.

ERDELJA, Krešimir; STOJAKOVIĆ, Igor. Tragom prošlosti 8. Udžbenik povijesti u osmom razredu osnovne škole. Zagreb: Školska knjiga, 2014.

FRKOVIĆ, Josip. „Knjiga akademika Pečarića i dr. Razuma donosi konačnu istinu o 18600 logoraša u Jasenovcu i 1360 smrtno stradalih". Portal Tjedno, 26. 1. 2019. Pristup ostvaren 5. 4. 2020. http://www.tjedno.hr/knjiga-akademika-pecarica-i-dr-razuma-donosi-konacnu-istinu-o-18-600-logorasa-u-jasenovcu-i-1360-smrtno-stradalih/.

GEIGER, Vladimir. „Brojidbeni pokazatelji o ljudskim gubicima Hrvatske u Drugom svjetskom ratu i poraću”. U: Represija i zločini komunističkog režima u Hrvatskoj. Zbornik radova, ur. Zorislav Lukić. Zagreb: Matica hrvatska, 2012, 51-90.

GEIGER, Vladimir. „Brojidbeni pokazatelji o žrtvama logora Jasenovac, 1941.-1945. (procjene, izračuni, popisi)”. Časopis za suvremenu povijest 45 (2013), br. 2: 211-242.

GEIGER, Vladimir. „Čemu služi Razum? O osvrtu dr. Stjepana Razuma na moj prikaz knjige prof. dr. Ive Goldsteina Jasenovac objavljen u Časopisu za suvremenu povijest 51 (2019), br. 1". Časopis za suvremenu povijest 51 (2019), br. 2: 619-629. 
GEIGER, Vladimir. „Dokon pop i jariće krsti’ ili jesu li postojali rasni zakoni u NDH?”. Portal Historiografija, 4. 3. 2016. Pristup ostvaren 5. 4. 2020. http://www.historiografija.hr/?p=1991.

GEIGER, Vladimir. „Ivo Goldstein, Jasenovac (Zaprešić; Jasenovac: Fraktura; Javna ustanova Spomen-područje Jasenovac, 2018) 958 str., [32 str.] s tablama: ilustr., zemljop. karte; 24 cm". Časopis za suvremenu povijest 51 (2019), br. 1: 269-314.

GEIGER, Vladimir. „Ljudski gubici Hrvatske u Drugom svjetskom ratu koje su prouzročili 'okupatori i njihovi pomagači'. Brojidbeni pokazatelji (procjene, izračuni, popisi)”. Časopis za suvremenu povijest 43 (2011), br. 3: 699-749.

GEIGER, Vladimir. „Nedostatno znanje, nestručnost i šlamperaj ili još jednom o izložbi Ako tebe zaboravim... Holokaust u Hrvatskoj 1941. - 1945. / zadnje odredište Auschwitz, Francuski paviljon u Zagrebu, 5. veljače - 21. travnja 2020." Časopis za suvremenu povijest 52 (2020), br. 1: 343-350.

GEIGER, Vladimir. „Sumanuti i bolesni navodi i tvrdnje Međunarodne komisije za utvrđivanje istine o Jasenovcu (The International Commission for the Truth on Jasenovac)". Politički zatvorenik (Zagreb), br. 253, srpanj/kolovoz 2013., 13-17.

GEIGER, Vladimir. „U povodu 10. travnja ili kako je Roman Leljak došao do 'otkrića' o ukupnom broju jasenovačkih logoraša - 18.600 i ukupnom broju žrtava logora Jasenovac - 1654?”. Portal Historigrafija, 8. 4. 2020. Pristup ostvaren 5. 5. 2020. http://www.historiografija.hr/?p=20204.

Genocid nad Srbima u II svetskom ratu. Međunarodni naučni skup Odbora Srpske akademije nauka i umetnosti za sakupljanje grade o genocidu protiv srpskog naroda i drugih naroda Jugoslavije u XX veku, održan od 23. do 25. oktobra 1991. godine, prir. Milan Bulajić, ur. Radovan Samardžić. Beograd: Muzej žrtava genocida; Srpska književna zadruga, 1995.

GOLDSTEIN, Ivo. „Genocid nad Židovima u Nezavisnoj Državi Hrvatskoj”. Povijest u nastavi II (2004), br. 1 (3): 40-50.

GOLDSTEIN, Ivo. „Istraživanje židovskih žrtava: razmatranja o Zagrebu i Hrvatskoj”. U: Dijalog povjesničara/istoričara, sv. 5, prir. Hans-Georg Fleck i Igor Graovac. Zagreb: Friedrich Naumann Stiftung, 2002, 445-463.

GOLDSTEIN, Ivo. Jasenovac. Zaprešić; Jasenovac: Fraktura; Javna ustanova Spomen-područje Jasenovac, 2018.

GOLDSTEIN, Ivo. Jasenovac. Novi Sad: Akademska knjiga, 2019.

GOLDSTEIN, Ivo. „Komisija za Jasenovac: nova besmislena inicijativa šefice države”. Jutarnji list (Zagreb), on-line izdanje, 5. 5. 2018. Pristup ostvaren 20. 11. 2018. https://www.jutarnji.hr/globus/Globus-komentari/pi- 
se-ivo-goldstein-komisija-za-jasenovac-nova-besmislena-inicijativa-sefice-drzave/7321071/.

GOLDSTEIN, Ivo. Kontroverze iz hrvatske povijesti 20. stoljeća. Zagreb: Profil, 2019.

GOLDSTEIN, Ivo. „O broju jasenovačkih i blajburških žrtava”. U: Slavko Goldstein, Ivo Goldstein, Jasenovac i Bleiburg nisu isto. Zagreb: Novi Liber, 2011, 307-317.

GOLDSTEIN, Ivo. „O broju žrtava jasenovačkog logorskog kompleksa”. U: Slavko Goldstein, suautor Ivo Goldstein, Jasenovac. Tragika, mitomanija, istina. Zagreb: Fraktura, 2016, 103-127.

GOLDSTEIN, Ivo. „Židovi u logoru Jasenovac”. U: Spomen područje Jasenovac, ur. Tea Benčić Rimay. Jasenovac: Spomen-područje Jasenovac, 2006, 108-153.

GOLDSTEIN, Ivo; GOLDSTEIN, Slavko. Holokaust u Zagrebu. Zagreb: Židovska općina Zagreb; Novi Liber, 2001.

GOLDSTEIN, Slavko; GOLDSTEIN, Ivo. Jasenovac i Bleiburg nisu isto. Zagreb: Novi Liber, 2011.

GOLDSTEIN, Slavko; GOLDSTEIN, Ivo. Jasenovac. Tragika, mitomanija, istina. Zagreb: Fraktura, 2016.

„Goldštajn [Ivo]: U Jasenovcu je stradalo oko 120.000 ljudi”. Politika (Beograd), on-line izdanje, 4. 4. 2019. Pristup ostvaren 28. 3. 2020. http://www.politika.rs/sr/clanak/426657/Goldstajn-U-Jasenovcu-je-stradalo-oko-120-000-ljudi.

GREIF, Gideon. Jasenovac - Auschwitz of the Balkans. The Ustasha Empire of Cruelty. Beograd: Knjiga komerc, 2018.

GRAJF, Gideon. „Jasenovac - Aušvic Balkana. Kontroverze o broju žrtava”. Politika (Beograd), br. 37809, 15. i 16. 2. 2019., 19.

[GRAJF, Gideon]. „U Jasenovcu je ubijeno možda i 800.000 Srba, Jevreja i Roma, o tome se NE SME ĆUTATI”. Blic (Beograd), on-line izdanje, 1. 2. 2019. Pristup ostvaren 15. 2. 2019. https://www.blic.rs/vesti/svet/u-jasenovcu-je-ubijeno-mozda-i-800000-srba-jevreja-i-roma-o-tome-se-ne-sme-cutati/r7h3pn8.

Hina. „Većinom glasova. Skupština odlučila - Sedlaru Nagrada grada Zagreba". Tportal, 19. 4. 2017. Pristup ostvaren 15. 5. 2020. https://www.tportal. $\mathrm{hr} /$ vijesti/clanak/skupstina-odlucila-sedlaru-nagrada-grada-zagreba-20170419.

HORVAT, Vladimir; VUKIĆ, Igor; PILIĆ, Stipo; MATKOVIĆ, Blanka. Jasenovački logori - istraživanja. Zagreb: Društvo za istraživanje trostrukog logora Jasenovac, 2015. 
„Intervju. Dr. Stjepan Razum, povjesničar i arhivist: Vrijeme je da srušimo velikosrpski mit o Jasenovcu. Nema dokaza za masovne ustaške zločine $u$ Jasenovcu, ali ima za partizanske!” [razgovarala: Andrea Černivec]. Hrvatski list (Zadar), br. 411, 9. 8. 2012., 28-35.

„Intervju. Dr. Stjepan Razum. U Jasenovcu partizani su svoje okrutne i masovne zločine podmetnuli ustašama - mi povjesničari to ćemo i dokazati!" [razgovarao: Ivica Marijačić]. Hrvatski tjednik (Zadar), br. 501, 1. 5. 2014., 30 33.

„Intervju. Fascinantni intervju koji će srušiti lažnu komunističku povijest. Mr. sc. Blanka Matković: Hrvatskoj je dosta lažne povijesti” [razgovarao: Ivica Marijačić]. Hrvatski tjednik (Zadar), br. 607, 13. 5. 2016., 29-44.

„Intervju. Mr. Mladen Ivezić, autor knjige 'Titov Jasenovac'. Ideološka i dnevnopolitička uloga jasenovačkog mita” [razgovarao: Tomislav Vuković]. Glas Koncila (Zagreb), br. 30 (2092), 27. 7. 2014., 6-7.

„Intervju. Redatelj Jakov Sedlar nedavno je završio dokumentarni film 'Jasenovac - istina' na kojemu je radio punih 12 godina. Film 'Jasenovac - istina': dosad najtočnije i povijesno najautentičnije djelo na tu temu” [razgovarala: Andrea Černivec]. Hrvatski tjednik (Zadar), br. 592, 28. 1. 2016., 44-47.

„Intervju. Roman Leljak o poslijeratnom logoru u Jasenovcu. Tito je naredio 21. kolovoza 1948. da se zatvori jasenovački logor" [razgovarao: Tomislav Vuković]. Glas Koncila (Zagreb), br. 1 (2220), 8. 1. 2017., 6-7.

„Ispravak”. Vjesnik (Zagreb), br. 12101, 7. 5. 1981., 3.

IVEZIĆ, Mladen. Jasenovac. Brojke. Zagreb: Samizdat, 2003.

IVEZIĆ, Mladen. Titov Jasenovac. Zagreb: Samizdat, 2014.

Izvješće o radu Komisije za utvrđivanje ratnih i poratnih žrtava od osnutka (11. veljače 1992.) do rujna 1999. godine. Zagreb: Komisija za utvrđivanje ratnih i poratnih žrtava Republike Hrvatske, rujan 1999.

JAZBEC, Salamon. Magnissimum crimen. Pola vijeka revizionizma u $\mathrm{Hr}$ vata. Zagreb: Margelov institut, 2008.

Jasenovac. Koncentracioni logor 1941-1945. Spisak ustaških žrtava identifikovanih do 30. X 1997., I-III. Beograd: Muzej žrtava genocida; Savezni zavod za statistiku, 1997.

Jasenovac. Peta Medunarodna konferencija o sistemu koncentracionih logora i stratišta hrvatske države za istrebljenje Srba, Jevreja i Roma u Drugom svjetskom ratu, Banja Luka, 24. i 25. maj 2011. godine. Zbornik radova, gl. ur. Smilja Avramov. Kozarska Dubica; Banja Luka: Javna ustanova Spomen-područja Donja Gradina; Udruženje Jasenovac - Donja Gradina, 2011. 
Jasenovac, sistem ustaških logora smrti. Saopštenja sa Okruglog stola održanog u Beogradu 23.4.1996., ur. Miloš Hamović. Beograd: Muzej žrtava genocida; Institut za savremenu istoriju, 1997.

Jasenovac. Zbornik XI medunarodne konferencije o holokaustu. Holokaust iz perspektive 21-og veka / Treća medunarodna konferencija o Jasenovcu. Jasenovac - anatomija zapostavljenih koncentracionih logora, Belgijska kuća, Hebrejski univerzitet, Univerzitetski centar Givat Ram, Jerusalim, Izrael 29-30. decembar 2002., gl. ur. Zdravko Antonić. Kozarska Dubica; Banja Luka: Javna ustanova Spomen-područja Donja Gradina; Udruženje Jasenovac - Donja Gradina, 2007.

Jasenovac. Zbornik radova Četvrte međunarodne konferencije o Jasenovcu, Banja Luka - Donja Gradina, 30-31. maj 2007., gl. ur. Zdravko Antonić. Kozarska Dubica; Banja Luka: Javna ustanova Spomen-područja Donja Gradina; Udruženje Jasenovac - Donja Gradina, 2007.

Jasenovac. Zbornik radova Prve medunarodne konferencije i izložbe o jasenovačkim koncentracionim logorima, 29-31. oktobra 1997. godine, Opštinski koled Kingsboro (Kingsborough) Gradskog univerziteta u Njujorku, gl. ur. Zdravko Antonić. Kozarska Dubica; Banja Luka: Javna ustanova Spomen-područja Donja Gradina; Udruženje Jasenovac - Donja Gradina, 2007.

Jasenovac. Žrtve rata prema podacima Statističkog zavoda Jugoslavije, prir. Meho Visočak i Bejdo Sobica. Zürich; Sarajevo: Bošnjački institut, 1998.

JOVANOVIĆ, Aleksandar S. Beg iz jasenovačkog pakla. Beograd: Muzej žrtava genocida, 2014.

JOVANOVIĆ, Aleksandar S. „Šta se znalo za vreme II svetskog rata o broju žrtava u NDH, prema podacima Saveznika i izvršiocima zločina”. U: Odgovornost države Hrvatske za izvršeni genocid nad srpskim narodom i drugim narodima u periodu 1941-1945. i 1991-1995. godine (Okrugli sto - Beograd, 9. marta 2007.), ur. Smilja Tišma. Beograd: Udruženja zatočenika i potomaka zatočenika logora genocida u Nezavisnoj Državi Hrvatskoj 1941-1945.; Pešić i sinovi, 2007, 63-73.

JURČEVIĆ, Josip. Die Entstehung des Mythos Jasenovac. Probleme bei der Forschungsarbeit zu den Opfern des II. Weltkrieges auf dem Gebiet von Kroatien. Zagreb: Dokumentacijsko informacijsko središte, 2007.

JURČEVIĆ, Josip. Nastanak jasenovačkog mita. Problemi proučavanja žrtava Drugog svjetskog rata na području Hrvatske. Zagreb: Hrvatski studiji Sveučilišta u Zagrebu, 1998.

JURIĆ, Bernardica. „Jasenovačke žrtve i uspostava nacionalnog programa u Srbiji (1986. - 1995.)”. Radovi Zavoda za hrvatsku povijest 49 (2017): 227-260. 
KASAPOVIĆ, Mirjana. „Genocid u NDH: Umanjivanje, banaliziranje i poricanje zločina”. Politička misao 55 (2018), br. 1: 7-33.

KASAPOVIĆ, Mirjana. „Vukićeva knjiga o Jasenovcu toksični je šund”. Globus (Zagreb), br. 1462, 14. 12. 2018., 34-37.

KATALINIĆ, Kazimir. Argumenti. NDH, BiH, Bleiburg i genocid. Buenos Aires; Zagreb: Časopis Republika Hrvatska, 1993.

KLJAKOVIĆ-ŠANTIĆ, Josip. Jasenovac - enigma holokausta. Zagreb: Tkanica d.o.o., 2016.

KOČOVIĆ, Bogoljub. Nauka, nacionalizam i propaganda (Između gubitaka $i$ žrtava Drugoga svetskog rata u Jugoslaviji). Paris: Editions du Titre, 1999.

KOČOVIĆ, Bogoljub. Sahrana jednog mita. Žrtve Drugog svetskog rata u Jugoslaviji. Beograd: Otkrovenje, 2005.

KOČOVIĆ, Bogoljub. Žrtve Drugog svetskog rata u Jugoslaviji. London: Naše delo, 1985.

KOČOVIĆ, Bogoljub. Žrtve Drugog svetskog rata u Jugoslaviji. Sarajevo: Svjetlost, 1990.

„Koncentracijski logori”. U: Hrvatska enciklopedija, sv. 6, Kn - Mak. Zagreb: Leksikografski zavod „Miroslav Krleža”, 2004, 83-85.

KOREN, Snježana. Povijest 8. Udžbenik povijesti za 8. razred osnovne škole. Zagreb: Profil, 2014.

KOREN, Snježana. Povijest 8. Udžbenik za 8. razred osnovne škole. Zagreb: Profil, 2003.

KOREN, Snježana. Povijest 8. Udžbenik za 8. razred osnovne škole. Zagreb: Profil, 2007.

KOVAČIĆ, Davor. „Jasenovac - žrtve rata prema podacima Statističkog zavoda Jugoslavije, Sarajevo - Zürich, 1998., 1171 str.” Časopis za suvremenu povijest 32 (2000), br. 1: 219-224.

KOZLICA, Ivan. „Muzej genocida iz Beograda - krivotvorenim podatcima do većeg broja žrtava Drugoga svjetskog rata. Ludilo velikosrpskih brojeva”. Hrvatski tjednik (Zadar), br. 687, 23. 11. 2017., 40-43.

KRANJČEV, Branko; ĆURKOVIĆ, Josip. „Poimenični popis Židova, žrtava koncentracijskog logora Jasenovac 1941.-1945. po naseljima općine Našice”. U: Židovi u našičkom kraju. Zbornik radova, ur. Silvija Lučevnjak. Našice: Udruga za hrvatsku povjesnicu Našice, 2011, 225-254.

KRESTIĆ, Vasilije Đ.; RADOJEVIĆ Mira. Jasenovac. Beograd: Srpska akademija nauka i umetnosti, 2017. 
KRUŠELJ, Željko. Zarobljenici paralelnih povijesti. Hrvatsko-srpska historiografska fronta na prijelazu stoljeća. Zagreb: Srednja Europa, 2018.

LELJAK, Roman. Mit o Jasenovcu. Dokumentarni film - dokumenti. Radenci: Društvo za raziskovanje zgodovine, 2018.

LUKAJIĆ, Lazar. Fratri i ustaše kolju - zločinci i svedoci. Beograd: Fond za istraživanje genocida, 2005.

LUKIĆ, Dragoje. Bili su samo deca. Jasenovac, grobnica 19.432 devojčice i dečaka, knj. 1-2. Laktaši; Beograd: GrafoMark; Muzej žrtava genocida, 2000.

LJUŠIĆ, Radoš; DIMIĆ, Ljubodrag. Istorija za osmi razred osnovne škole. Beograd: Freska, 2010.

MATAUŠIĆ, Nataša. Jasenovac 1941.-1945. Logor smrti i radni logor. Jasenovac; Zagreb: Javna ustanova Spomen-područje Jasenovac; Jesenski i Turk, 2003.

MATAUŠIĆ, Nataša. „Koncentracioni logor Jasenovac”. U: Spomen područje Jasenovac, ur. Tea Benčić Rimay. Jasenovac: Spomen-područje Jasenovac, 2006, 46-71.

MATAUŠIĆ, Nataša. Koncentracioni logor Jasenovac. Fotomonografija. Jasenovac: Spomen-područje Jasenovac, 2008.

MATKOVIĆ, Blanka. „Kako je nastao i razvijao se velikosrpski jasenovački mit i zašto je ostao službeni, državni kult, čak i u današnjoj Hrvatskoj?”. Hrvatski tjednik (Zadar), br. 709, 26. 4. 2018., 29-33.

„Međunarodna komisija za utvrđivanje istine o Jasenovcu”. Wikipedija. Pristup ostvaren 20. 4. 2020. http://sr.wikipedia.org/sr-el/Међународна_ комисија_за_утврђивање_истине_о_Јасеновцу.

MIHOVILOVIĆ, Đorđe; SMREKA, Jelka. „O poimeničnom popisu žrtava KL Jasenovac prema do sada prikupljenim i provjerenim podacima”. U: Spomen područje Jasenovac, ur. Tea Benčić Rimay. Jasenovac: Spomen-područje Jasenovac, 2006, 218-219.

MILETIĆ, Antun. NDH - Koncentracioni logor Jasenovac 1941-1945. Beograd: Antun Miletić, 2010.

MILETIĆ, Antun. Koncentracioni logor Jasenovac 1941-1945. Dokumenta, knj. I. Beograd; Jasenovac: Narodna knjiga; Spomen-područje Jasenovac, 1986.

MILETIĆ, Antun. „O bilansu smrti u koncentracionom logoru Jasenovac (1941-1945)". U: Genocid nad Srbima u II svetskom ratu. Međunarodni naučni skup Odbora Srpske akademije nauka i umetnosti za sakupljanje građe o genocidu protiv srpskog naroda $i$ drugih naroda Jugoslavije u XX veku, održan od 23. do 25. oktobra 1991. godine, prir. Milan Bulajić, ur. Radovan Samardžić. Beograd: Muzej žrtava genocida; Srpska književna zadruga, 1995, 207-223. 
MILETIĆ, Antun. „Prilog utvrđivanja imenom broja usmrćenih u koncentracionom logoru Jasenovac". U: Jasenovac, sistem ustaških logora smrti. Saopštenja sa Okruglog stola održanog u Beogradu 23.4.1996., ur. Miloš Hamović. Beograd: Muzej žrtava genocida; Institut za savremenu istoriju, 1997, 50-88.

MILETIĆ, Antun. Ubijeni u koncentracionom logoru Jasenovac 1941-1945. = The Assassinated in the Jasenovac Concentration Camp 1941-1945. Jagodina: Gambit, 2011.

MIRKOVIĆ, Jovan. „Građa o jasenovačkom logoru”. U: Jasenovac. Zbornik radova Četvrte međunarodne konferencije o Jasenovcu, Banja Luka - Donja Gradina, 30-31. maj 2007., gl. ur. Zdravko Antonić. Kozarska Dubica; Banja Luka: Javna ustanova Spomen-područja Donja Gradina; Udruženje Jasenovac - Donja Gradina, 2007, 23-37.

MIRKOVIĆ, Jovan. „Hronologija zločina (april - avgust 1941. godine) prilog dokazima o genocidnom karakteru Nezavisne Države Hrvatske”. U: Prilozi istraživanju genocida i ratnih zločina. Zbornik radova, ur. Jovan Mirković. Beograd: Muzej žrtava genocida, 2009, 11-78.

MIRKOVIĆ, Jovan. „Izdanja Muzeja žrtava genocida i građa o ljudskim gubicima u tim izdanjima”. U: Dijalog povjesničara/istoričara, sv. 7, prir. Hans-Georg Fleck i Igor Graovac. Zagreb: Friedrich Naumann Stiftung, 2003, 573-591.

MIRKOVIĆ, Jovan. Objavljeni izvori i literatura o jasenovačkim logorima. Laktaši; Banja Luka; Beograd: GrafoMark; Besjeda; Muzej žrtava genocida, 2000.

MIRKOVIĆ, Jovan. „Poimenična identifikacija - prilog metodologiji utvrđivanja broja žrtava genocida i ratnih zločina (na primeru NDH)”. U: Treća međunarodna konferencija Stradanje Srba, Jevreja, Roma i ostalih na teritoriji bivše Jugoslavije. Zbornik radova = Third International Conference Suffering of Serbs, Jews, Roma and Others in the Former Yugoslavia. Proceedings, ur. Života Radosavljević, Vjačeslav Solovjov i Olja Arsenijević. Beograd: Fakultet za poslovne studije i pravo i Fakultet za strateški i operativni menadžment, Univerzitet „Union - Nikola Tesla”, 2016, 57-69.

MIRKOVIĆ, Jovan. „Predgovor”/„Forward”. U: Zemaljska komisija Hrvatske za utvrđivanje zločina okupatora i njihovih pomagača. „Zločini u logoru Jasenovac" = Croatian State Commission for Establishing Crimes of Occupying Forces and Their Assistants. „Crimes in the Jasenovac Camp”. Banja Luka: Besjeda, 2000, V-XXIX/5-31.

MIRKOVIĆ, Jovan. Zločini and Srbima u Nezavisnoj Državi Hrvatskoj = Crimes against the Serbs in the Independent state of Croatia. Beograd: Svet knjiga, 2014. 
MIRKOVIĆ, Jovan. „Žrtve rata 1941-1945. sa područja Bosanske krajine - prilog istraživanju genocida”. U: Istraživanja i memorijalizacija genocida $i$ ratnih zločina. Zbornik radova, ur. Jovan Mirković. Beograd: Muzej žrtava genocida, 2012, 11-52.

MIROŠEVIĆ, Franko; ŠANJEK, Franjo; MACAN, Trpimir; MIJATOVIĆ, Anđelko. Povijest. Udžbenik za II. razred strukovnih škola. Zagreb: Školska knjiga, 1999.

MITROVIĆ, Goran. „Tito dokumentaciju o Jasenovcu tajno prebacio u Vatikan! Otkrivena strogo čuvana tajna”. Portal Republika, 21. 9. 2019. Pristup ostvaren 27. 3. 2020. https://www.republika.rs/vesti/srbija/158407/tito-dokumentaciju-jasenovcu-tajno-prebacio-vatikan-otkrivena-strogo-cuvana-tajna.

MOTL, Dejan; MIHOVILOVIĆ, Đorđe. Zaboravljeni. Knjiga o posljednjim jasenovačkim logorašima. Jasenovac; Zagreb: Javna ustanova Spomen-područje Jasenovac; Savez antifašističkih boraca i antifašista RH, 2015.

MRĐA, Jovana. „Stradanje srpske, romske i jevrejske dece u logorima NDH". U: Druga međunarodna konferencija Holokaust nad Srbima, Jevrejima $i$ Romima u Drugom svetskom ratu. Zbornik radova = Second International Conference Holokaust over the Serbs, Jews and Roma during the Second World War. Proceedings, ur. Vojislav Vučenović, Vjačeslav Solovjov, Edit Der Šeregelj i Željko Simić. Beograd: Fakultet za poslovne studije i pravo i Fakultet za strateški i operativni menadžment, Univerzitet „Union - Nikola Tesla”, 2015, 89-99.

MRKOCI, Vladimir; HORVAT, Vladimir. Ogoljela laž logora Jasenovac. Zagreb: Naklada E. Čić, 2008.

„Nije sto hiljada malo”. Muzej genocida žrtava. Pristup ostvaren 27. 3. 2020. http://arhiva.muzejgenocida.rs/images/za \%20muzej \%20001_PDF.pdf.

NIKODIJEVIĆ, Dušan. „Brojevi žrtava u koncentracionom logoru Jasenovac 1942. godine prema iskazima preživelih svedoka”. Godišnjak za istraživanje genocida 9 (2017): 95-117.

NIKODIJEVIĆ, Dušan. „Brojevi žrtava u koncentracionom logoru Stara Gradiška 1942. godine prema iskazima preživelih svedoka”. Godišnjak za istraživanje genocida 10 (2018): 127-155.

NIKODIJEVIĆ, Dušan. „Brojevi žrtava u sistemu koncentracionog logora Jasenovac 1943-1945. godine prema iskazima preživelih svedoka”. Godišnjak za istraživanje genocida 11/1 (2019): 137-172.

NIKODIJEVIĆ, Dušan. Jasenovac između broja i žrtve. Prilog proučavanju broja žrtava u sistemu koncentracionog logora Jasenovac. Beograd: Muzej žrtava genocida, 2019. 
NIKODIJEVIĆ, Dušan. „Prilog utvrđivanju broja žrtava sistema logora Jasenovac 1941. godine”. Godišnjak za istraživanje genocida 8 (2016): 169-213.

NIKOLIĆ, Kosta. „Polemike o genocidu u NDH u jugoslovenskoj istoriografiji 1985-1989." U: Genocid u 20. veku na prostorima jugoslovenskih zemalja, ur. Jovan Mirković. Beograd: Muzej žrtava genocida; Institut za noviju istoriju Srbije, 2005, 425-452.

Odgovornost države Hrvatske za izvršeni genocid nad srpskim narodom i drugim narodima u periodu 1941-1945. i 1991-1995. godine (Okrugli sto - Beograd, 9. marta 2007.), ur. Smilja Tišma. Beograd: Udruženja zatočenika i potomaka zatočenika logora genocida u Nezavisnoj Državi Hrvatskoj 1941-1945.; Pešić i sinovi, 2007.

„Otkrivamo - Jasenovac - fotošopirana istina: Sedlarov udarni argument o plivanju leševa uzvodno je loša montaža”. Portal Lupiga, 7. 4. 2016. Pristup ostvaren 27. 3. 2020. https://lupiga.com/vijesti/otkrivamo-jasenovac-fotosopirana-istina-sedlarov-udarni-argument-o-plivanju-leseva-uzvodno-je-losa-fotomontaza.

PEČARIĆ, Josip. Brani li Goldstein NDH. Zagreb: „A. G. Matoš” d.d. Samobor; Autor, 2002.

PEČARIĆ, Josip. Srpski mit o Jasenovcu. Skrivanje istine o beogradskim konc-logorima. Zagreb: Dom i svijet; Hrvatski informativni centar; Hrvatski institut za povijest, ${ }^{1} 1998$; Zagreb: Element, ${ }^{2} 2000$.

PEČARIĆ, Josip. Srpski mit o Jasenovcu II. O Bulajićevoj ideologiji genocida hrvatskih autora. Zagreb: Element, 2000.

PEČARIĆ, Josip; RAZUM, Stjepan. Razotkrivena jasenovačka laž. Zagreb: Društvo za istraživanje trostrukog logora Jasenovac, 2018.

PERIĆ, Ivo. Povijest za VIII. razred osnovne škole. Zagreb: Školska knjiga, 1992.

„Poimenični popis žrtava KCL Jasenovac 1941-1945.” Spomen područje Jasenovac. Pristup ostvaren 10. 2. 2019. http://www.jusp-jasenovac.hr/Default. aspx?sid=6284.

Poimenični popis žrtava koncentracijskog logora Jasenovac 1941.-1945., prir. Jelka Smreka i Đorđe Mihovilović. Jasenovac: Spomen-područje Jasenovac, 2007.

Politika Svet (Beograd), exclusive broj 1, april 1990.: „Istina o genocidu nad Srbima, Jevrejima, Ciganima i drugima”.

Popis žrtava rata 1941-1945. III. Uputstvo za izvršenje popisa. Beograd: Savezno izvršno veće Socijalističke Federativne Republike Jugoslavije Komisija za popis žrtava rata, avgust 1964. 
Prva međunarodna konferencija Holokaust nad Srbima, Jevrejima i Romima u Drugom svetskom ratu. Zbornik radova = First International Conference Holokaust over the Serbs, Jews and Roma during the Second World War. Proceedings, ur. Vojislav Vučenović, Vjačeslav Solovjov i Edit Der Šeregelj. Beograd: Fakultet za poslovne studije i pravo i Fakultet za strateški i operativni menadžment, Univerzitet „Union - Nikola Tesla”, 2014.

PSD. „Najnovije istraživanje Muzeja žrtava genocida iz Beograda. Muzej žrtava genocida iz Beograda: U NDH je ubijeno oko pola milijuna logoraša”. Slobodna Dalmacija (Split), on-line izdanje, 13. 5. 2009. Pristup ostvaren 27. 3. 2020. https://slobodnadalmacija.hr/vijesti/hrvatska/muzej-zrtava-genocida-iz-beograda-u-ndh-je-ubijeno-oko-pola-milijuna-logorasa-52338.

PSD. „Slaven Letica: Moj brat, koji je umro u El Shattu, pretvoren je u žrtvu Jasenovca”. Slobodna Dalmacija (Split), on-line izdanje, 16. 2. 2011. Pristup ostvaren 20. 4. 2020. https://slobodnadalmacija.hr/vijesti/hrvatska/slaven-letica-moj-brat-koji-je-umro-u-el-shattu-pretvoren-je-u-zrtvu-jasenovca-124679.

RADOJEVIĆ, Mira. „Jasenovac, logor smrti (1941-2016)” = „Jasenovac, death concentration camp (1941-2016)”. U: Vasilije Đ. Krestić, Mira Radojević, Jasenovac. Beograd: Srpska akademija nauka i umetnosti, 2017, 49-93.

RAZUM, Stjepan. „Jasenovac, najveća povijesna laž koja iz dana u dan postaje sve prozirnija”. Hrvatski tjednik (Zadar), br. 559, 11. 6. 2015., 18-25.

RAZUM, Stjepan. „Logor Jasenovac kao sredstvo trajne komunističke indoktrinacije". Hrvatski tjednik (Zadar), br. 581, 12. 11. 2015., 18-20.

Savezna komisija za popis žrtava rata 1941-1945., „Izveštaj o izvršenom popisu žrtava rata 1941-1945.“ U: Žrtve rata 1941-1945. godine. (Rezultati popisa). Beograd: Savezni zavod za statistiku, avgust 1966., VII - XV.

„Smena direktora Muzeja žrtava genocida”. Udruženje građana „Jadovno 1941.”, 13. 11. 2019. Pristup ostvaren 27. 3. 2020. https://jadovno.com/smenjen-direktor-muzeja-zrtava-genocida/\#.Xn48HIhKiM8.

SMILJANIĆ, Radomir. „Prekrajanje istorije u funkciji ubijanja Srbije”. U: Prva medunarodna konferencija Holokaust nad Srbima, Jevrejima i Romima u Drugom svetskom ratu. Zbornik radova = First International Conference Holokaust over the Serbs, Jews and Roma during the Second World War. Proceedings, ur. Vojislav Vučenović, Vjačeslav Solovjov i Edit Der Šeregelj. Beograd: Fakultet za poslovne studije i pravo i Fakultet za strateški i operativni menadžment, Univerzitet „Union - Nikola Tesla”, 2014, 79-83.

SOBOLEVSKI, Mihael. „Između Jasenovca i Bleiburga”. Erasmus (studeni 1993), br. 4: 42-47. 
SOBOLEVSKI, Mihael. „Pogrešno istrčavanje Vladimira Žerjavića”. Časopis za suvremenu povijest 26 (1994), br. 2: 351-359.

SOBOLEVSKI, Mihael. „Prešućena istina - žrtve rata na području bivše Jugoslavije 1941.-1945. prema popisu iz 1964. godine”. Časopis za suvremenu povijest 25 (1993), br. 2-3: 87-114.

SOBOLEVSKI, Mihael. „Prilog metodologiji istraživanja stvarnih ljudskih gubitaka Hrvatske u tijeku drugoga svjetskog rata”. Časopis za suvremenu povijest 24 (1992), br. 1: 203-212.

Spisak žrtava rata 1941-1945. Ustaški logor Jasenovac. Beograd: Savezni zavod za statistiku, 1992.

„Srpski svećenik Ćulibrk i Židov Zuroff žele pripisati srpska ubojstva Židova Paveliću!”. Portal HOP, 8. 4. 2018. Pristup ostvaren 15. 5. 2020. https:// www.hop.com.hr/2018/04/08/srpski-svecenik-culibrk-i-zidov-zuroff-zele-pripisati-srpska-ubojstva-zidova-pavelicu/.

STIPANKOV, Ines; KALIČANIN, Milica; KALIČANIN, Zoran. „Ustaški koncentracioni logori u NDH”. U: Druga međunarodna konferencija Holokaust nad Srbima, Jevrejima i Romima u Drugom svetskom ratu. Zbornik radova = Second International Conference Holokaust over the Serbs, Jews and Roma during the Second World War. Proceedings, ur. Vojislav Vučenović, Vjačeslav Solovjov, Edit Der Šeregelj i Željko Simić. Beograd: Fakultet za poslovne studije i pravo i Fakultet za strateški i operativni menadžment, Univerzitet „Union - Nikola Tesla”, 2015, 179-187.

„Stipe Mesić osporava 'istinu’ o Jasenovcu!”. YouTube. Pristup ostvaren 15. 5. 2020. https://www.youtube.com/watch?v=PcnJ5NDrDYw.

ŠEŠELJ, Vojislav. Rimokatolički zločinački projekat veštačke hrvatske nacije. Beograd: Srpska radikalna stranka, 2007.

ŠKILJAN, Filip. „Logorski sustav Jasenovac - kontroverze”. U: Nezavisna Država Hrvatska 1941. - 1945., ur. Sabrina P. Ramet. Zagreb: Alinea, 2009, 117-130.

ŠKILJAN, Filip. Politički zatvorenici u logorima Jasenovac i Stara Gradiška. Zagreb: Spomen područje Jasenovac, 2009.

TERZIĆ, Velimir. Slom Kraljevine Jugoslavije 1941 - uzroci i posledice. Beograd; Titograd: Narodna knjiga; Partizanska knjiga; Pobjeda, 1982.

TRIFKOVIĆ, Srdja. „Ustaša crimes, Serbian victims, numbers and politics: toward a rational debate". Istorija 20. veka 38 (2020), br. 1: 203-222.

TRIFKOVIĆ, Srdja. Ustaše: Balkansko srce tame na evropskoj političkoj sceni. Beograd: BIGZ, ${ }^{1}$ 1999; Beograd: Catena Mundi, ${ }^{2} 2016$. 
TUĐMAN, Franjo. Bespuća povijesne zbiljnosti. Rasprava o povijesti i filozofiji zlosilja. Zagreb: Nakladni zavod Matice hrvatske, 1989.

VAJAGIĆ, Predrag M.; STOŠIĆ, Nenad. Istorija 8. Udžbenik za osmi razred osnovne škole. Beograd: Klett, 2010.

„Victim’s List”. Jasenovac Research Institute, ožujak 2006. Pristup ostvaren 20. 4. 2020. https://jasenovac.org/victim_list.php.

VLAHOVIĆ, Marin. „Roman Leljak: Dokumentacija Vojnog arhiva u Beogradu potvrđuje genocid pola milijuna Hrvata”. Portal Dnevno, 31. 12. 2017. Pristup ostvaren 3. 4. 2020. https://www.dnevno.hr/vijesti/hrvatska/roman-leljak-dokumentacija-vojnog-arhiva-u-beogradu-potvrduje-genocid-pola-milijuna-hrvata-1112234/.

VUKIĆ, Igor. „Cirkus sa žrtvama nastavlja se jer su u laži kratke noge. Plenković otvorio tragikomičnu izložbu o holokaustu, Jasenovcu... Žrtve Auschwitza s izložbe istodobno su i na popisu žrtava Jasenovca!”. Hrvatski tjednik (Zadar), br. 803, 13. 2. 2020., 24-26.

VUKIĆ, Igor. Jasenovac iz dana u dan. Kronologija. Zagreb: Naklada Pavičić, 2019.

VUKIĆ, Igor. Radni logor Jasenovac. Zagreb: Naklada Pavičić, 2018.

VUKIĆ, Igor. „Sabirni i radni logor Jasenovac, 1941.-1945.” U: Vladimir Horvat, Igor Vukić, Stipo Pilić, Blanka Matković, Jasenovački logori - istraživanja. Zagreb: Društvo za istraživanje trostrukog logora Jasenovac, 2015, 55-144.

VUKOVIĆ, Tomislav. Kako je nastao mit (o 20.101 ubijenom djetetu u jasenovačkom logoru). Zagreb: Glas Koncila, 2016.

VUKOVIĆ, Tomislav. „Otvoreno pismo episkopu, gospodinu Jovanu Ćulibrku. Episkope Ćulibrče, koliko je niških specijalaca poginulo u borbama za Vukovar. Vaš ugled niškog specijalca omogućio Vam je članstvo povjesničara u nizu znanstvenih komisija, posebice o holokaustu, Jasenovcu, bl. Stepincu". Hrvatski tjednik (Zadar), br. 806, 5. 3. 2020., 20-23.

Zemaljska komisija Hrvatske za utvrđivanje zločina okupatora i njihovih pomagača. „Zločini u logoru Jasenovac” = Croatian State Commission for Establishing Crimes of Occupying Forces and Their Assistants. „Crimes in the Jasenovac Camp”. Banja Luka: Besjeda, 2000.

Zločini u logoru Jasenovac. Zagreb: Zemaljska komisija Hrvatske za utvrđivanje zločina okupatora i njihovih pomagača, 1946.

[ZMAJO]. „Jasenovac. Dosje Ante Pavelića: Popis osoba stradalih u logoru Jasenovac". Portal Croatia Rediviva, 3. 3. 2017. Pristup ostvaren 3. 4. 2020. 
http://croatiarediviva.com/2017/03/03/dosje-ante-pavelica-popis-osoba-stradalih-logoru-jasenovac/.

ZUROVAC, Mirko. „Genocid pod plaštom 'demokratije”. U: Zatiranje Srba u Hrvatskoj, prir. Bogdan Zlatar. Beograd: IKP Nikola Pašić, 2008, 245267.

ŽERJAVIĆ, Vladimir. „Demografski i ratni gubici Hrvatske u Drugom svjetskom ratu i poraću”. Časopis za suvremenu povijest 27 (1995), br. 3: 543 560.

ŽERJAVIĆ, Vladimir. „Demografski pokazatelji o stradanju Židova u NDH”. U: Antisemitizam, holokaust, antifašizam, ur. Ognjen Kraus. Zagreb: Židovska općina Zagreb, 1996, 133-138.

ŽERJAVIĆ, Vladimir. „Demographic Indicators of the Jewish Ordeal in the Independent State of Croatia”. U: Anti-Semitism, Holocaust, Anti-Fascism, ed. Ognjen Kraus. Zagreb: Jewish Community, 1997, 73-77.

ŽERJAVIĆ, Vladimir. Gubici stanovništva Jugoslavije u drugom svjetskom ratu. Zagreb: Jugoslavensko viktimološko društvo, 1989.

ŽERJAVIĆ, Vladimir. „Gubici stanovništva Jugoslavije u drugom svjetskom ratu”. U: Političko-geografska i demografska pitanja Hrvatske, gl. ur. Ivan Crkvenčić. Zagreb: Savez geografskih društava Hrvatske, 1991, 83-106.

ŽERJAVIĆ, Vladimir. „Manipulacije žrtvama drugoga svjetskog rata 1941. - 1945." Časopis za suvremenu povijest 24 (1992), br. 3: 149-163.

ŽERJAVIĆ, Vladimir. „Nije pogrešno istrčavanje već razmatranje mogućnosti daljnjeg istraživanja žrtava drugog svjetskog rata”. Časopis za suvremenu povijest 26 (1994), br. 3: 517-527.

ŽERJAVIĆ, Vladimir. „O stradanjima u Drugom svjetskom ratu: stradali Hrvati od četnika, stradali Srbi i broj stradalih u Jasenovcu”. U: Dijalog povjesničara/istoričara, sv. 5, prir. Hans-Georg Fleck i Igor Graovac. Zagreb: Friedrich Naumann Stiftung, 2002, 565-571.

ŽERJAVIĆ, Vladimir. Opsesije i megalomanije oko Jasenovca i Bleiburga. Gubici stanovništva Jugoslavije u drugom svjetskom ratu. Zagreb: Globus, 1992.

ŽERJAVIĆ, Vladimir. „Osvrt na napis Mihaela Sobolevskog o popisu žrtava rata 'Prešućena istina - žrtve rata na području bivše Jugoslavije 1941.-1945. prema popisu iz 1964. god.” Časopis za suvremenu povijest 26 (1994), br. 1: 123-134.

ŽERJAVIĆ, Vladimir. Pertes de la population en Yougoslavie 1941-1945. Zagreb: Dom i svijet; Hrvatski institut za povijest, 1997.

ŽERJAVIĆ, Vladimir. Population losses in Yugoslavia 1941-1945. Zagreb: Dom i svijet; Hrvatski institut za povijest, 1997. 
ŽERJAVIĆ, Vladimir. „Stradanja Jugoslavena u drugom svjetskom ratu”. Viktimologija 1 (1990), br. 1-2: 39-48.

ŽERJAVIĆ, Vladimir. [„The Most Likely Number of Victims of the Jasenovac Camp"]. U: Jasenovac. Zbornik radova Prve međunarodne konferencije i izložbe o jasenovačkim koncentracionim logorima, 29-31. oktobra 1997. godine, Opštinski koleđ Kingsboro (Kingsborough) Gradskog univerziteta u Njujorku, gl. ur. Zdravko Antonić. Kozarska Dubica; Banja Luka: Javna ustanova Spomen-područja Donja Gradina; Udruženje Jasenovac - Donja Gradina, 2007, 205-210.

ŽERJAVIĆ, Vladimir. Yugoslavia - manipulations with the numbers of Second World War victims = Yougoslavie - manipulations sur le nombre des victimes de la Seconde guerre mondiale = Jugoslawien - Manipulationen mit Kriegsopfern des zweiten Weltkriegs = Jugoslavija - manipulacije žrtvama Drugog svjetskog rata. Zagreb: Croatian Information Centre = Hrvatski informativni centar, 1993.

ŽIVANOVIĆ, Srboljub. Jasenovac. Odabrani radovi, članci, intervjui, govori i diskusije. Beograd; London: Srpska knjiga; Međunarodna slovenska akademija nauka, obrazovanja i umetnosti, Odeljenje za Veliku Britaniju i Irsku, 2008.

ŽIVANOVIĆ, Srboljub. Jasenovac 2. Beograd; London: Pešić i sinovi; Međunarodna slovenska akademija nauka, kulture, obrazovanja i umetnosti, Odelenje za Veliku Britaniju i Irsku, 2017.

„Živanoviću nagrada za knjigu 'Jasenovac”. Radio-televizija Vojvodine, 12. 2. 2010. Pristup ostvaren 15. 2. 2020. http://www.rtv.rs/sr_lat/kultura/zivanovicu-nagrada-za-knjigu-jasenovac_173273.html.

ŽIVKOVIĆ, Biljana. Jasenovac, Kozara, Jadovno. Beograd: Institut za istraživanje srpskih stradanja u 20. veku, 2016.

ŽIVKOVIĆ, Nikola; KAČAVENDA, Petar. Srbi u Nezavisnoj Državi Hrvatskoj. Izabrana dokumenta. Beograd: Institut za savremenu istoriju, 1998.

Žrtve rata 1941-1945. godine. (Rezultati popisa). Beograd: Savezni zavod za statistiku, avgust 1966. 


\section{SUMMARY}

\section{The Issue of the Number of Jasenovac Camp Victims in Croatian and Serbian Historiography, Opinion Journalism, and Public Discourse after the Disintegration of the Socialist Federal Republic of Yugoslavia - Facts, Controversies, and Manipulations}

The most controversial and unresolved issue of human losses of Croatia and Yugoslavia in World War II is the number of victims of the Jasenovac camp. Lists of victims and estimates and calculations by historians and demographers often diverge widely on this point, ranging from minimisation to impossible megalomaniac claims, and are strongly linked to (daily) politics. Especially after the disintegration of the Socialist Federal Republic of Yugoslavia, the issue of the number of victims of the Jasenovac camp began to be interpreted differently from the until then only permitted one-sided and 'megalomaniac' approach. Democratic changes, but also rising nationalist sentiment during the Yugoslav Wars of the 1990s, led to studies on the human losses of Yugoslavia in World War II, and the unavoidable issue of the number and structure of Jasenovac camp victims, having a distinct ideological-propaganda background in Croatian and Serbian historiography, opinion journalism, and public discourse. Serb nationalists vastly inflate the number of Jasenovac camp victims, most of all Serbs, while Croat nationalists strive to minimise this number. The issue of the number and structure of Jasenovac victims is heavily nationally, ideologically, and emotionally charged, which greatly hinders evaluation. Proponents of both left and right worldviews in Croatia and Serbia continue to ignore and belittle any research and facts that do not support their favoured image of the past. Furthermore, they devaluate proven facts and present typical justifications. Inflation or reduction, omission, often coupled with ignorance, stem from personal, national, or political motives. It is noticeable that both Croatian and Serbian media, for the most part, transmit such efforts. The Jasenovac camp and the number and structure of its victims continue to be popular discussion topics in Croatian and Serbian historiography and opinion journalism, which have stratified into the left and right within national frameworks since the early 1990s, and in Croatian and Serbian public discourse; very different, sometimes diametrically opposed statements and claims are made, often without basis in fact. Facts about the Jasenovac camp have been contaminated from the start, and we are still witnessing contamination from various sources, with no end in sight. Despite all the efforts of a part of Croatian and Serbian historiography, and some opin- 
ion journalism, no major progress has been made from the early 1990s until today regarding the research and aggregation of knowledge and new data on the number and structure of Jasenovac camp victims; our level of knowledge in this regard has remained more-or-less the same as in the pre-1990 period. There is no doubt that historiography, Croatian and Serbian, has yet to present substantiated answers about the number and structure of Jasenovac victims. This article presents and questions the most significant Croatian and Serbian historiographical and opinion journalism works - as well as the unavoidable echoes of the topic of Jasenovac victims in public discourse - that question the number and structure of the victims, including those that offer substantiated facts, but also some illustrative examples of indisputable ignorance and manipulation.

Key words: Independent State of Croatia; Jasenovac concentration camp; victims; controversies; manipulations. 